Highly Enantioselective and Regioselective Nickel-Catalyzed Coupling of Allenes, Aldehydes, and Silanes

Ng, S.-S.; Jamison, T. F. *

Massachusetts Institute of Technology, Department of Chemistry, Cambridge, MA 02139

Supporting Information

Experimental Procedures, Analytical and Spectroscopic Data for Compounds 1a-5d.

Pages S2 - S22

References

Page S22

${ }^{1} \mathrm{H}$ and ${ }^{13} \mathrm{C}$ NMRs for compounds $\mathbf{1 a}-\mathbf{5 d}$.

Pages S23 - S63 


\section{General Information.}

Unless otherwise noted, all reactions were performed under an oxygen-free atmosphere of nitrogen or argon with rigid exclusion of moisture from reagents and glassware. Tetrahydrofuran was distilled from a blue solution of sodium benzophenone ketyl. Dichloromethane was distilled from calcium hydride. Triethylsilane, tert-butyldimethylsilane and dimethylphenylsilane were purchased from Aldrich Chemical Co. and were saturated with nitrogen before use. Benzaldehyde was purchased from Aldrich Chemical Co., distilled by bulb to bulb distillation and then saturated with nitrogen before storage under nitrogen. Other aromatic aldehydes were purchased from Aldrich Chemical Co. and were used without further purification. Bis(cyclooctadienyl)nickel(0) $\left(\mathrm{Ni}(\mathrm{cod})_{2}\right)$ and tricyclopentylphosphine were purchased from Strem Chemicals, Inc., stored under nitrogen atomosphere and used without further purification. 1,3Bis-(2,6-di-isopropylphenyl)imidazol-2-ylidene (NHC-IPr) was prepared according to literature procedure. ${ }^{1}$ Triethylsilane-d was prepared according to literature procedure. ${ }^{2}$ Cyclohexanecarboxaldehyde, methyl lithium, Amano lipase, vinylacetate, acetaldehyde, methyl- $(R)$-mandelate, cyclohexaneacetic acid and Mosher's acid were purchased from Aldrich Chemical Co. and used as received (unless otherwise noted). Carbon tetrabromide, triphenylphosphine and 4-(dimethylamino)-pyridine were purchased from Alfa Aesar and used as received. tert-butylacetylene and 1-pentyne were purchased from GFS and used as received. Diethylazodicarboxylate was purchased from Lancaster and used as received. Dicyclohexylcarbodiimide was purchased from Pierce and used as received.

Analytical thin layer chromatography (TLC) was performed using EM Science silica gel $60 \mathrm{~F}_{254}$ plates. The developed chromatogram was analyzed by UV lamp $(254 \mathrm{~nm})$, ethanolic phosphomolybdic acid (PMA) or potassium permanganate $\left(\mathrm{KMnO}_{4}\right)$. Liquid chromatography was performed using a forced flow (flash chromatography) of the indicated solvent system on Silicycle Silica Gel (230 - 400 mesh). ${ }^{1} \mathrm{H}$ and ${ }^{13} \mathrm{C}$ NMR spectra were recorded on Varian $300 \mathrm{MHz}$, Varian $500 \mathrm{MHz}$ or Bruker $400 \mathrm{MHz}$ spectrometer in $\mathrm{CDCl}_{3}$ or $\mathrm{C}_{6} \mathrm{D}_{6}$, unless otherwise noted. Chemical shifts in ${ }^{1} \mathrm{H} \mathrm{NMR}$ spectra are reported in parts per million ( $\mathrm{ppm})$ on the $\delta$ scale from an internal standard of residual chloroform $(7.27 \mathrm{ppm})$ or residual benzene $(7.16 \mathrm{ppm})$. Data are reported as follows: chemical shift, multiplicity $(\mathrm{s}=$ singlet, $\mathrm{d}=$ doublet, $\mathrm{t}=$ triplet, $\mathrm{q}=$ quartet, $\mathrm{m}=$ multiplet, $b=$ broad), coupling constant in hertz $(\mathrm{Hz})$, and integration. Chemical shifts of

${ }^{13} \mathrm{C}$ NMR spectra are reported in ppm from the central peak of $\mathrm{CDCl}_{3}(77.23 \mathrm{ppm})$ on the $\delta$ scale. Infrared (IR) spectra were recorded on a Perkin-Elmer 2000 FT-IR. High resolution mass spectra (HRMS) were obtained on a Bruker Daltonics APEXII 3 Tesla Fourier Transform Mass Spectrometer by Dr. Li Li of the Massachusetts Institute of 
Technology Department of Chemistry Instrument Facility. Chiral GC analysis was performed on a Varian CP-3800 gas chromatograph fitted with Chiraldex B-PH, B-DA, and G-TA capillary columns. Chiral HPLC analysis was performed on a Hewlett-Packard 1100 chromatograph equipped with a variable wavelength detector and Chiralcel OD or OD-H columns. Specific Rotations $\left([\alpha]_{D}\right)$ were measured on a Perkin-Elmer 241 polarimeter at $589 \mathrm{~nm}$.

\section{Preparation of 1,3-disubstituted allenes.}

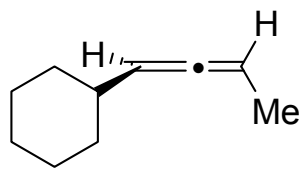

(aS)-buta-1,2-dienyl-cyclohexane (2b).

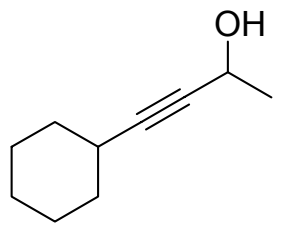

a. Preparation of (+/-)-4-cyclohexyl-but-3-yn-2-ol. Carbontetrabromide (73 g, $220 \mathrm{mmol})$ was dissolved in anhydrous dichloromethane $(150 \mathrm{~mL})$. The solution was cooled to $0{ }^{\circ} \mathrm{C}$, triphenylphosphine (115 g, $\left.440 \mathrm{mmol}\right)$ was added. The mixture was stirred $30 \mathrm{~min}$ at $0{ }^{\circ} \mathrm{C}$. Cyclohexanecarboxaldehyde $(10 \mathrm{~mL}, 110 \mathrm{mmol})$ was added and the reaction mixture was slowly warmed to room temperature and stirred $12 \mathrm{~h}$. The brown precipitate was removed by filtering the $\mathrm{CH}_{2} \mathrm{Cl}_{2}$ solution through silica gel and the silica gel was washed with hexane. Evaporation of the solvents gave an oil with white precipitate. The crude was diluted with hexane and filtered through silica gel to yield a colorless oil (2,2-dibromo-vinyl)-cyclohexane (21.62 g, 74\% yield). It was used without further purification. (2,2-Dibromo-vinyl)-cyclohexane $(9.18 \mathrm{~g}, 34 \mathrm{mmol})$ was dissolved in anhydrous THF $(40 \mathrm{~mL})$ and was cooled to $-78^{\circ} \mathrm{C}$. Methyllithium $(55 \mathrm{~mL}$, $88 \mathrm{mmol}, 1.6 \mathrm{M}$ in ether) was added to the solution over $5 \mathrm{~min}$ and the mixture was stirred $2.5 \mathrm{~h}$ at $-78{ }^{\circ} \mathrm{C}$. Acetaldehyde was added in one portion and the mixture was stirred $1.5 \mathrm{~h}$ and was warmed to room temperature. The reaction was quenched with water and extracted with diethylether $(1 \times 80 \mathrm{~mL})$, which was washed with water and dried with $\mathrm{MgSO}_{4}$. Column chromatography afforded a yellow oil (+/-)-4-cyclohexyl-but-3-yn-2-ol (4.9 g, 94\% yield). 


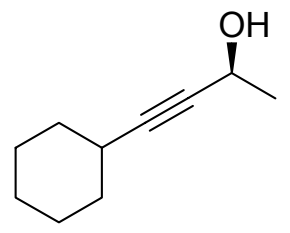

b. Preparation of enantiomerically enriched (S)-4-cyclohexyl-but-3-yn-2-ol by lipase resolution. ${ }^{3}$ In an oven-dried round bottom flask, (+/-)4-cyclohexyl-but-3-yn-2-ol (2.28 g, $15 \mathrm{mmol})$ was dissolved in anhydrous pentane (50 $\mathrm{mL}$ ) at room temperature. $4 \AA$ molecular sieves (approximately half the volume of the solvent), Amano lipase AK from pseudomonas fluorescens $(2 \mathrm{~g})$ followed by freshly distilled vinyl acetate $(4 \mathrm{~mL}, 40 \mathrm{mmol})$ were added. The slurry was stirred $5 \mathrm{~h}$ at room temperature. NMR of the crude reaction mixture indicated that the ratio of acetate to alcohol was approximately 1:1. The mixture was stirred for 30 more minutes, filtered through celite and washed with pentane. Column chromatography afforded (S)-4-cyclo-hexyl-but-3-yn-2-ol (1.1 g, 99\% yield based on 50\% conversion) that was at least $98 \%$ ee according to Mosher's ester analysis. The absolute configuration was determined by Mosher's ester analysis. ${ }^{4}$ It was consistent with the specific rotations of similar compounds prepared from the same method. ${ }^{3}$

${ }^{1} \mathrm{H}$ NMR (400 MHz, $\left.\mathrm{CDCl}_{3}, \delta\right): 4.53(\mathrm{~m}, 1 \mathrm{H}), 2.42-2.30(\mathrm{~m}, 1 \mathrm{H}), 1.9-1.2(\mathrm{~m}, 10 \mathrm{H})$, $1.43(\mathrm{~d}, J=6.5 \mathrm{~Hz}, 3 \mathrm{H})$.

${ }^{13} \mathrm{C}$ NMR (100 MHz, $\left.\mathrm{CDCl}_{3}, \delta\right): 89.0,82.3,58.8,32.8,29.1,26.0,25.1$.

IR (NaCl, thin film): 3333, 2931, 2854, 2240, 1449, 1158, 1078, 897.

HRMS-ESI (m / z): [M + Na $]^{+}$calcd for $\mathrm{C}_{10} \mathrm{H}_{16} \mathrm{O}, 175.109$; found, 175.109 . $[\alpha]^{20}-23.0^{\circ}\left(\mathrm{c} 1.00, \mathrm{CHCl}_{3}\right)$

Mosher's ester analysis: (+/-)-4-cyclohexyl-but-3-yn-2-ol was converted into a pair of diastereomers of $(R)$-Mosher's esters (DCC, DMAP, $(R)$-Mosher's acid, $\left.\mathrm{CH}_{2} \mathrm{Cl}_{2}\right)^{5}$. The methyl doublets $(\delta 1.50$ and $1.56 \mathrm{ppm})$ of the two diastereomers were well resolved by ${ }^{1} \mathrm{H}$ NMR and were assigned according to the method of Mosher. ${ }^{4}$

$\delta 1.56(d)$

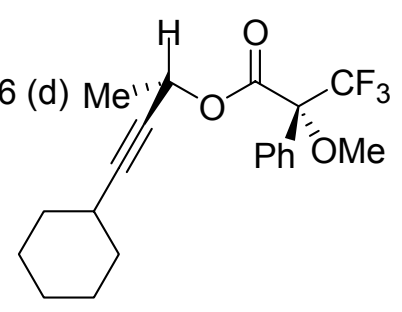


The enantiomerically-enriched alcohol was then converted to $(R)$-Mosher's ester, and a doublet was observed at $\delta 1.56 \mathrm{ppm}$. Therefore, 4-cyclo-hexyl-but-3-yn-2-ol prepared from lipase resolution had an absolute configuration of $(S)$.<smiles>CC=C=CC1CCCCC1</smiles>

c. Preparation of (aS)-buta-1,2-dienyl-cyclohexane by the method of Myers $^{6}$ (2b). Triphenylphosphine (5 g, $15 \mathrm{mmol}$ ) was dissolved in THF (20 mL). The solution was cooled in a $\mathrm{MeOH} /$ ice bath, and diethylazodicarboxylate (DEAD) (2.4 mL, $15 \mathrm{mmol}$ ) was added to the solution over $1 \mathrm{~min}$. The solution was stirred $10 \mathrm{~min}$ below $-10{ }^{\circ} \mathrm{C}$. (S)-4-cyclohexyl-but-3-yn-2-ol (1.52 g, $\left.10 \mathrm{mmol}\right)$ in THF $(10 \mathrm{~mL})$ was added. THF ( $5 \mathrm{~mL}$ ) was used to rinse the rest of the alcohol into the reaction mixture. The mixture was stirred $10 \mathrm{~min}$, and $o$-nitrobenzenesulfonyl- hydrazine ${ }^{7}$ (3.3 g, $15 \mathrm{mmol}$ in $20 \mathrm{~mL}$ THF) was added. The mixture was kept below $0{ }^{\circ} \mathrm{C}$ for $2 \mathrm{~h}$ and was allowed to warm to room temperature and stirred $16 \mathrm{~h}$. The reaction was cooled to $0{ }^{\circ} \mathrm{C}$, diluted with pentane $(200 \mathrm{~mL})$ and washed 10 times with ice cold water to remove THF. Column chromatography in pentane afforded (aS)-buta-1,2-dienyl-cyclohexane $(0.95 \mathrm{~g}, 70 \%$ yield, 98\% ee based on chiral GC analysis). The absolute configuration of the allene was determined $^{6}$ based on the absolute configuration of the alcohol and was consistent with Lowes-Brewster rule. ${ }^{8}$ The spectral data are consistent with literature values. ${ }^{9}$

${ }^{1} \mathrm{H}$ NMR (400 MHz, $\left.\mathrm{CDCl}_{3}, \delta\right): 5.09(\mathrm{~m}, 1 \mathrm{H}), 5.04(\mathrm{~m}, 1 \mathrm{H}), 2.00-1.91(\mathrm{~m}, 1 \mathrm{H}), 1.80-$ $1.00(\mathrm{~m}, 10 \mathrm{H}), 1.65(\mathrm{dd}, J=3.4,7.0 \mathrm{~Hz}, 3 \mathrm{H})$.

${ }^{13} \mathrm{C}$ NMR (100 MHz, $\left.\mathrm{CDCl}_{3}, \delta\right): 203.7,96.7,86.5,37.4,33.3,26.4,26.3,15.0$.

IR (NaCl, thin film): 2924, 2852, 1965, 1448, 960, 869, 711.

HRMS-ESI (m / z): $[\mathrm{M}+\mathrm{Na}]^{+}$calcd for $\mathrm{C}_{10} \mathrm{H}_{16}, 136.125$; found, 136.125. $[\alpha]^{20}{ }_{\mathrm{D}}+76.7^{\circ} \quad\left(\mathrm{c} 1.46, \mathrm{CHCl}_{3}\right)$

Chiral GC analysis: (Chiraldex B-DA, $60{ }^{\circ} \mathrm{C}$ isotherm, $\left.1.5 \mathrm{~mL} / \mathrm{min}\right): \mathrm{t}_{\mathrm{R}}(\mathrm{a} S)=21.1 \mathrm{~min}$; $\mathrm{t}_{\mathrm{R}}(\mathrm{a} R)=22.6 \min$. 


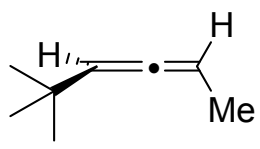

(aS)-5,5-dimethyl-hexa-2,3-diene (2c).

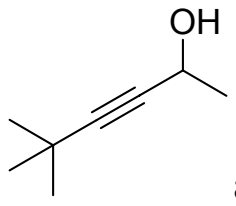

a. Preparation of (+/-)-5,5-dimethyl-hex-3-yn-2-ol. THF $(80 \mathrm{~mL})$ was cooled to $-78{ }^{\circ} \mathrm{C}$. tert-butylacetylene $(7.35 \mathrm{~mL}, 60 \mathrm{mmol})$ was added. MeLi $(56 \mathrm{~mL}, 90$ mmol, $1.6 \mathrm{M}$ in diethylether) was added via a syringe pump over $10 \mathrm{~min}$. The mixture was stirred $1 \mathrm{~h}$ at $-78{ }^{\circ} \mathrm{C}$. Acetaldehyde $(6.7 \mathrm{~mL}, 120 \mathrm{mmol})$ was added. The mixture was stirred at $-78{ }^{\circ} \mathrm{C}$ for one more hour and warmed to room temperature. The reaction was cooled to $0{ }^{\circ} \mathrm{C}$ and quenched with water. The cold mixture was diluted with diethylether $(150 \mathrm{~mL})$ and washed two times with water. The ether solution was dried by $\mathrm{MgSO}_{4}$ and was filtered through silica gel. The silica gel was washed with diethyl ether. The NMR of the crude reaction mixture indicated 5,5-dimethyl-hex-3-yn-2-ol along with some cyclotrimer of acetaldehyde. (53.4 mmol alcohol based on NMR integration, 89\% yield). The crude product was used without further purification.

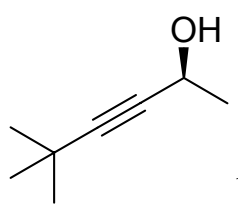

b. Preparation of (S)-5,5-dimethyl-hex-3-yn-2-ol by lipase resolution.

Prepared using the same lipase resolution procedure as described above (lipase, $4 \AA$ MS, vinylacetate, pentane, room temperature, 5.5 h. $88.5 \%$ isolated yield. $>98 \%$ ee based on chiral GC analysis and Mosher's ester analysis).

${ }^{1} \mathrm{H}$ NMR (400 MHz, $\mathrm{CDCl}_{3}, \delta$ ): 4.49 (q, $\left.J=6.5 \mathrm{~Hz}, 1 \mathrm{H}\right), 2.1$ (bs, $\left.1 \mathrm{H}\right), 1.39(\mathrm{~d}, J=6.5 \mathrm{~Hz}$, $3 \mathrm{H}), 1.19$ (s, 9H).

${ }^{13} \mathrm{C}$ NMR (100 MHz, $\left.\mathrm{CDCl}_{3}, \delta\right): 92.9,80.9,68.1,58.6,31.2,25.0$.

IR (NaCl, thin film): 3336, 2971, 2237, 1363, 1263, 1125, 1050, 973, 882.

$[\alpha]^{20}-27.3^{\circ}\left(\mathrm{c} 1.06, \mathrm{CHCl}_{3}\right)$

Mosher's ester analysis: (+/-)-5,5-dimethyl-hex-3-yn-2-ol was converted into a pair of diastereomers of $(R)$-Mosher's esters (DCC, DMAP, $(R)$-Mosher's acid, $\left.\mathrm{CH}_{2} \mathrm{Cl}_{2}\right)^{5}$. The methyl doublets $(\delta 1.48$ and $1.54 \mathrm{ppm})$ and $t$-Bu singlets $(\delta 1.19$ and $1.21 \mathrm{ppm})$ of the two diastereomers were well resolved by ${ }^{1} \mathrm{H}$ NMR and were assigned according to the 
method of Mosher. ${ }^{4}$

(S)

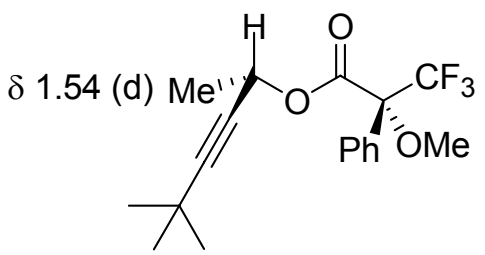

$\delta 1.19$ (s)
(R)

(R)

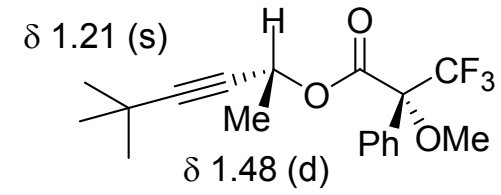

The enantiomerically-enriched alcohol was converted to $(R)$-Mosher's ester. A doublet was observed at $\delta 1.54 \mathrm{ppm}$, and a singlet was observed at $\delta 1.19 \mathrm{ppm}$. Therefore, 5,5-dimethyl-hex-3-yn-2-ol prepared from lipase resolution had an absolute configuration of $(S)$.

Chiral GC analysis: (Chiraldex B-PH, $60{ }^{\circ} \mathrm{C}$ isotherm, $0.3 \mathrm{~mL} / \mathrm{min}$ ): $\mathrm{t}_{\mathrm{R}}(S)=69.0 \mathrm{~min}$; $\mathrm{t}_{\mathrm{R}}(R)=72.3 \mathrm{~min}$.

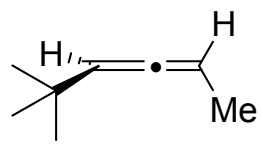

c. Preparation of (aS)-5,5-dimethyl-hexa-2,3-diene (2c). Prepared using

the same method as described above for $\mathbf{2} \mathbf{b}$. After the removal of THF by an aqueous workup, the pentane solution was filtered through a pad of silica gel to remove most of the by-products. The pentane was removed by rotavap at atmospheric pressure, and the last traces of pentane were removed by fractional distillation. Finally, the product was separated from the crude mixture by distilling under high vacuum at room temperature, collecting in a cooled flask, affording $60 \%$ of (aS)-5,5-dimethyl-hexa-2,3-diene. The absolute configuration of the allene was assigned ${ }^{6}$ based on the absolute configuration of the alcohol and was consistent with Lowes-Brewster rule. ${ }^{8}$

${ }^{1} \mathrm{H} \mathrm{NMR} \mathrm{(400} \mathrm{MHz,} \mathrm{CDCl}_{3}, \delta$ ): 5.12 (quintet , $J=6.8 \mathrm{~Hz}, 1 \mathrm{H}$ ), 5.06 (dq, $J=3.3,6.42 \mathrm{~Hz}$, $1 \mathrm{H}), 1.67$ (dd, $J=3.3,6.9 \mathrm{~Hz}, 3 \mathrm{H}), 1.04(\mathrm{~s}, 9 \mathrm{H})$.

${ }^{13} \mathrm{C}$ NMR (100 MHz, $\mathrm{CDCl}_{3}, \delta$ ): 202.1, 102.6, 87.4, 31.9, 30.4, 15.1 .

IR ( $\mathrm{NaCl}$, thin film): 2962, 1962, 1462, 1363, 1192, 873, 725.

$[\alpha]^{20}{ }_{D}+67.7^{\circ}\left(\mathrm{c} 1.24, \mathrm{CHCl}_{3}\right)\left(\right.$ consistent with similar compounds $\left.{ }^{10}\right)$ 


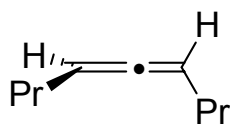

(aS)-nona-4,5-diene (2a). Prepared using the same method as $\mathbf{2 b}$ and $\mathbf{2 c}$ from $(S)$-non-5-yn-4-ol, which was prepared by lipase resolution using the procedure described above (60\% yield from $(S)$-non-5-yn-4-ol, 95\% ee). The absolute configuration was assigned by comparing the specific rotation of $\mathbf{2 a}$ with the literature value ${ }^{11}$ and is also consistent with the Lowes-Brewster rule. ${ }^{8}$

${ }^{1} \mathrm{H}$ NMR (400 MHz, $\mathrm{CDCl}_{3}, \delta$ ): 5.07 (m, 2H), 1.97 (m, 4H), 1.44 (sextet, $J=7.3 \mathrm{~Hz}, 4 \mathrm{H}$ ), $0.94(\mathrm{t}, J=7.3 \mathrm{~Hz}, 6 \mathrm{H})$.

${ }^{13} \mathrm{C}$ NMR $\left(100 \mathrm{MHz}, \mathrm{CDCl}_{3}, \delta\right): 204.2,90.8,31.4,22.7,13.9$.

IR ( $\mathrm{NaCl}$, thin film): 2960, 2931, 1963, 1464, 879.

$[\alpha]^{20}{ }_{\mathrm{D}}+64.0^{\circ} \quad\left(\mathrm{c} 1.00, \mathrm{CHCl}_{3}\right)$

$[\alpha]^{20}{ }_{\mathrm{D}}+84.7^{\circ} \quad(\mathrm{c} 0.72, \mathrm{EtOH})$

Literature ${ }^{11}[\alpha]^{20}{ }_{\mathrm{D}}+80.0^{\circ} \quad(\mathrm{c} 0.69, \mathrm{EtOH})$

Chiral GC analysis: (Chiraldex B-PH, $35{ }^{\circ} \mathrm{C}$ isotherm, $0.1 \mathrm{~mL} / \mathrm{min}$ ): $\mathrm{t}_{\mathrm{R}}(\mathrm{a} R)=74.7 \mathrm{~min}$; $\mathrm{t}_{\mathrm{R}}(\mathrm{a} S)=81.2 \mathrm{~min}$.

\section{Nickel-catalyzed reductive couplings of allenes and aldehdyes.}

General procedure. A $25 \mathrm{~mL}$ round bottom flask and a stir bar were oven-dried and brought into a glove box. Ni(cod) $)_{2}(28 \mathrm{mg}, 0.1 \mathrm{mmol}, 20 \mathrm{~mol} \%)$ and NHC-IPr $(78 \mathrm{mg}$, $0.2 \mathrm{mmol}, 40 \mathrm{~mol} \%$ ) were added to the round bottom flask, the flask was sealed with a septum, and the sealed flask was brought out of the glove box and connected to an argon line. The catalyst mixture was dissolved in THF $(7.5 \mathrm{~mL})$ under argon and stirred $10 \mathrm{~min}$ at room temperature. The solution was cooled to $-78{ }^{\circ} \mathrm{C}$ in a dry ice / acetone bath. After $10 \mathrm{~min}$ of cooling, triethylsilane ( $240 \mu \mathrm{L}, 1.5 \mathrm{mmol}, 300 \mathrm{~mol} \%)$, tert-butyldimethylsilane ( $250 \mu \mathrm{L}, 1.5 \mathrm{mmol}, 300 \mathrm{~mol} \%$ ), or dimethylphenylsilane ( $233 \mu \mathrm{L}, 1.5 \mathrm{mmol}, 300 \mathrm{~mol} \%$ ), as specified below, was added in one portion. Next the aldehyde (1.5 mmol, $300 \mathrm{~mol} \%)$ was added in one portion. The mixture was stirred $5 \mathrm{~min}$ at $-78^{\circ} \mathrm{C}$. The allene $(0.5 \mathrm{mmol}$, $100 \mathrm{~mol} \%$ ) was added to the reaction mixture in one portion. The reaction was kept in the dry ice / acetone bath and the bath was allowed to warm to room temperature over $6 \mathrm{~h}$. The reaction was stirred an additional $12 \mathrm{~h}$ at room temperature. ${ }^{1} \mathrm{H}$ NMR of an aliquot of the crude (after filtering through a plug of silica) indicated the allylic alcohol was the 
major coupling product along with minor impurities assigned as various homoallylic alcohols. The ratio of the allylic to homoallylic products was determined by the ${ }^{1} \mathrm{H} N \mathrm{NR}$ integration of spectrum of the crude mixture (Refer to Table 1 for the ratio). THF and excess silane were removed under reduced pressure and the crude mixture was diluted in hexane. Purification via flash chromatography on silica afforded the allylic alcohol coupling product.<smiles>CCOC(CC(C)C)C1=CPC=CC=C1</smiles>

(2-Butyl-1-phenyl-hex-2-enyloxy)-triethyl-silane (3a). The reaction of (aS)-nona-4,5-diene (2a) $(82 \mu \mathrm{L}, 0.5 \mathrm{mmol})$ and benzaldehyde $(152 \mu \mathrm{L}, 1.5$ $\mathrm{mmol}$ ) with $\mathrm{Ni}(\mathrm{cod})_{2}$, NHC-IPr and triethylsilane in THF following the general procedure described above afforded $\mathbf{3 a}$ in $77 \%$ isolated yield and $95 \%$ ee as determined by chiral HPLC. The absolute configuration of the stereocenter was determined by Mosher's ester analysis to be $R$. The olefin geometry was determined to be $\mathrm{Z}$ by a nOe experiment (see below).

${ }^{1} \mathrm{H}$ NMR (500 MHz, $\left.\mathrm{CDCl}_{3}, \delta\right): 7.16-7.40(\mathrm{~m}, 5 \mathrm{H}) ; 5.76(\mathrm{~s}, 1 \mathrm{H}) ; 5.24(\mathrm{t}, J=7.3 \mathrm{~Hz}$, $1 \mathrm{H}) ; 2.27$ (q, $J=7.5 \mathrm{~Hz}, 2 \mathrm{H}) ; 2.02(\mathrm{~m}, 1 \mathrm{H}) ; 1.74(\mathrm{~m}, 1 \mathrm{H}) ; 1.51$ (sextet, $J=7.5 \mathrm{~Hz}, 2 \mathrm{H}$ ); $1.14-1.34(\mathrm{~m}, 4 \mathrm{H}) ; 1.01$ (t, $J=6.7 \mathrm{~Hz}, 3 \mathrm{H}) ; 0.97$ (t, $J=7.6 \mathrm{~Hz}, 9 \mathrm{H}) ; 0.81$ (t, $J=7.0 \mathrm{~Hz}$, $3 \mathrm{H}) ; 0.64$ (q, $J=7.9 \mathrm{~Hz})$.

${ }^{13} \mathrm{C}$ NMR $\left(100 \mathrm{MHz}, \mathrm{CDCl}_{3}, \delta\right): 144.5,141.9,128.0,126.5,125.6,125.4,71.3,31.0$, $30.4,29.6,23.6,22.9,14.34,14.26,7.11,7.07$.

IR (NaCl, thin film): 2957, 2875, 1458, 1063, 742, 698.

HRMS-ESI (m / z): $[\mathrm{M}+\mathrm{Na}]^{+}$calcd for $\mathrm{C}_{22} \mathrm{H}_{38} \mathrm{OSi}, 369.258$; found, 369.259. $[\alpha]^{20}{ }_{D}-75.2^{\circ}\left(\mathrm{c} 1.07, \mathrm{CHCl}_{3}\right)$

Chiral HPLC analysis: Analysis was performed on the corresponding free alcohol, obtained by the deprotection of 3a (TBAF, THF): (Chiralcel OD, hexanes: 2-propanol, 99:1, $1.0 \mathrm{~mL} / \mathrm{min}): \mathrm{t}_{\mathrm{R}}(S)=9.7 \mathrm{~min} ; \mathrm{t}_{\mathrm{R}}(R)=10.8 \mathrm{~min}$.

Mosher's ester analysis: (+/-)-3a was first converted into the free alcohol (TBAF, THF) and was then converted into a pair of diastereomers of $(R)$-Mosher's esters (DCC, DMAP, $(R)$-Mosher's acid, $\left.\mathrm{CH}_{2} \mathrm{Cl}_{2}\right)^{5}$. The vinyl triplets $(\delta 5.45$ and $5.51 \mathrm{ppm})$ of the two 
diastereomers were well resolved by ${ }^{1} \mathrm{H}$ NMR and were assigned according to the method of Mosher. $^{4}$

(S) $\quad(\mathrm{R})$

$\delta 5.51(\mathrm{t})$
$(\mathrm{R})$

$(\mathrm{R})$

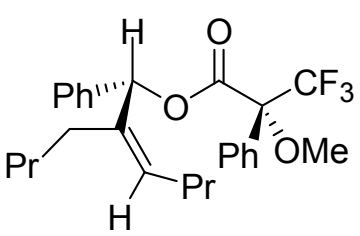

$\delta 5.45(\mathrm{t})$

The enantiomerically-enriched 3a was then converted to $(R)$-Mosher's ester using the same procedure. ${ }^{5}$ The vinyl triplet was observed at $\delta 5.46 \mathrm{ppm}$. Therefore 3a had an absolute configuration of $(R)$.

NOE DIFF experiment: Pre-saturation of the carbinol proton of 3a gave no nOe to the vinylic proton ( $\delta 5.24 \mathrm{ppm})$, but $13 \% \mathrm{nOe}$ was observed for the allylic protons indicated $(\delta 2.27 \mathrm{ppm})$. These results supported a $\mathrm{Z}$ olefin geometry.

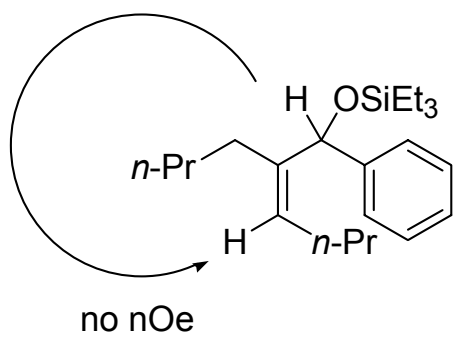<smiles>CCCC=CC(C=CCCC)C(OCC)c1ccccc1</smiles><smiles>CCOC(/C(=C\P)CCC(C)C)c1ccccc1C</smiles>

(2-Butyl-1-o-tolyl-hex-2-enyloxy)-triethyl-silane (3b). The reaction of (aS)-nona-4,5-diene (2a) $(82 \mu \mathrm{L}, 0.5 \mathrm{mmol})$ and $o$-tolualdehyde $(174 \mu \mathrm{L}, 1.5$ $\mathrm{mmol})$ with $\mathrm{Ni}(\mathrm{cod})_{2}$, NHC-IPr and triethylsilane in THF following the general procedure described above afforded $\mathbf{3 b}$ in $66 \%$ yield and $95 \%$ ee as determined by chiral HPLC. The absolute configuration of the stereocenter was assigned as $R$ in analogy to $\mathbf{3 a}$ and $\mathbf{3 j}$ whose configurations were established by Mosher's ester analysis.

${ }^{1} \mathrm{H}$ NMR (400 MHz, $\left.\mathrm{CDCl}_{3}, \delta\right): 7.71$ (bd, $\left.J=7.6 \mathrm{~Hz}, 1 \mathrm{H}\right), 7.21$ (bt, $\left.J=7.4 \mathrm{~Hz}, 1 \mathrm{H}\right), 7.13$ 
$(\mathrm{dt}, J=1.4,7.4 \mathrm{~Hz}, 1 \mathrm{H}), 7.04(\mathrm{bd}, J=7.4 \mathrm{~Hz}, 1 \mathrm{H}), 5.75(\mathrm{~s}, 1 \mathrm{H}), 5.20(\mathrm{t}, J=6.6 \mathrm{~Hz}, 1 \mathrm{H})$, $2.38-2.22(\mathrm{dq}, J=7.5,14.8 \mathrm{~Hz}, 2 \mathrm{H}), 2.20$ (s, 3H), 1.91 (ddt, $J=1.1,5.4,10.32 \mathrm{~Hz}, 1 \mathrm{H})$, 1.65 (ddt, $J=1.0,6.7,9.8 \mathrm{~Hz}, 1 \mathrm{H}), 1.49$ (sextet, $J=6.9 \mathrm{~Hz}, 2 \mathrm{H}), 1.16$ (m, 3H), 1.03 (t, $J$ $=5.6 \mathrm{~Hz}, 4 \mathrm{H}), 0.94(\mathrm{t}, J=8.0 \mathrm{~Hz}, 9 \mathrm{H}), 0.77$ (t, $J=7.1 \mathrm{~Hz}, 3 \mathrm{H}), 0.60$ (q, $J=7.5 \mathrm{~Hz}, 6 \mathrm{H})$.

${ }^{13} \mathrm{C}$ NMR (100 MHz, $\left.\mathrm{CDCl}_{3}, \delta\right): 142.2,139.1,134.2,129.8,126.9,126.7,126.5,125.6$, 69.1, 31.7, 30.6, 30.5, 23.5, 22.8, 19.6, 14.4, 14.2, 7.1, 5.2.

IR (NaCl, thin film): 2957, 2875, 1462, 1061, 1006, 744.

HRMS-ESI (m / z): $[\mathrm{M}+\mathrm{Na}]^{+}$calcd for $\mathrm{C}_{23} \mathrm{H}_{40} \mathrm{OSi}$, 383.274; found, 383.274 . $[\alpha]_{\mathrm{D}}^{20}-75.2^{\circ}\left(\mathrm{c} 1.25, \mathrm{CHCl}_{3}\right)$

Chiral HPLC analysis: Analysis was performed on the corresponding free alcohol, obtained by the deprotection of 3b (TBAF, THF) (Chiralcel OD, hexanes: 2-propanol, 99:1, $1.0 \mathrm{~mL} / \mathrm{min}): \mathrm{t}_{\mathrm{R}}(S)=11.4 \mathrm{~min} ; \mathrm{t}_{\mathrm{R}}(R)=14.1 \mathrm{~min}$.

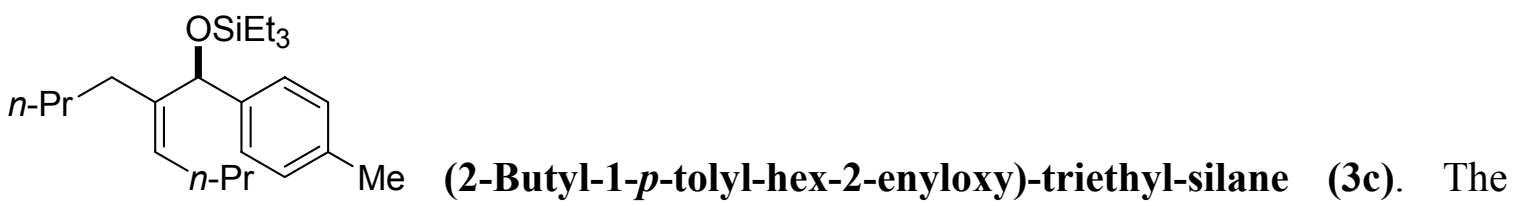
reaction of (aS)-nona-4,5-diene (2a) $(82 \mu \mathrm{L}, 0.5 \mathrm{mmol})$ and $p$-tolualdehyde $(177 \mu \mathrm{L}, 1.5$ $\mathrm{mmol})$ with $\mathrm{Ni}(\mathrm{cod})_{2}$, NHC-IPr and triethylsilane in THF following the general procedure described above afforded $3 \mathrm{c}$ in $74 \%$ yield and $95 \%$ enantiomeric excess as determined by chiral HPLC. The absolute configuration of the stereocenter was assigned as $R$ in analogy to $\mathbf{3 a}$ and $\mathbf{3 j}$ whose configuration were established by Mosher's ester analysis.

${ }^{1} \mathrm{H}$ NMR (500 MHz, $\left.\mathrm{CDCl}_{3}, \delta\right): 7.24$ (d, $\left.J=7.9 \mathrm{~Hz}, 2 \mathrm{H}\right), 7.11(\mathrm{~d}, J=7.6 \mathrm{~Hz}, 2 \mathrm{H}), \quad 5.74$ $(\mathrm{s}, 1 \mathrm{H}), 5.22(\mathrm{t}, J=7.0 \mathrm{~Hz}, 1 \mathrm{H}), 2.34(\mathrm{~s}, 3 \mathrm{H}), 2.27$ (q, $J=7.3 \mathrm{~Hz}, 2 \mathrm{H}), 2.03(\mathrm{~m}, 1 \mathrm{H}), 1.74$ (m, 1H), 1.50 (sextet, $J=7.3 \mathrm{~Hz}, 2 \mathrm{H}), 1.38-1.18(\mathrm{~m}, 4 \mathrm{H}), 1.00(\mathrm{t}, J=7.3 \mathrm{~Hz}, 3 \mathrm{H}), 0.97$ (t, $J=7.9 \mathrm{~Hz}, 9 \mathrm{H}), 0.82(\mathrm{t}, J=7.0 \mathrm{~Hz}, 3 \mathrm{H}), 0.63(\mathrm{q}, J=7.9 \mathrm{~Hz}, 6 \mathrm{H})$.

${ }^{13} \mathrm{C}$ NMR $\left(125 \mathrm{MHz}, \mathrm{CDCl}_{3}, \delta\right): 142.0,141.5,136.0,128.7,125.6,125.1,71.2,31.0$, $30.3,29.6,23.6,22.9,21.3,14.33,14.28,7.1,5.1$.

IR ( $\mathrm{NaCl}$, thin film): 2957, 2875, 1458, 1073, 1006, 741.

HRMS-ESI (m/z): $[\mathrm{M}+\mathrm{Na}]^{+}$calcd for $\mathrm{C}_{23} \mathrm{H}_{40} \mathrm{OSi}$, 383.274; found, 383.275 . $[\alpha]_{\mathrm{D}}^{20}-83.8^{\circ}\left(\mathrm{c} 1.05, \mathrm{CHCl}_{3}\right)$

Chiral HPLC analysis: Analysis was performed on the corresponding free alcohol, obtained by the deprotection of 3c (TBAF, THF): (Chiralcel OD, hexanes: 2-propanol, 
100:0, $1.5 \mathrm{~mL} / \mathrm{min}): \mathrm{t}_{\mathrm{R}}(R)=37.7 \mathrm{~min} ; \mathrm{t}_{\mathrm{R}}(S)=49.1 \mathrm{~min}$.

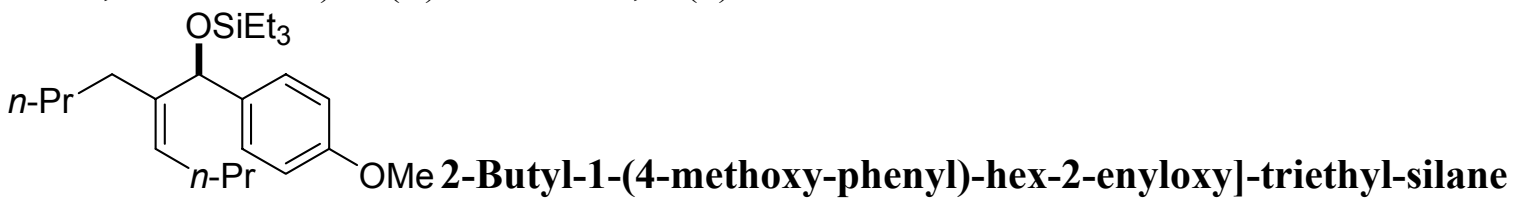

(3d). The reaction of (aS)-nona-4,5-diene (2a) $(82 \mu \mathrm{L}, 0.5 \mathrm{mmol})$ and $p$-anisaldehyde $(183 \mu \mathrm{L}, 1.5 \mathrm{mmol})$ with $\mathrm{Ni}(\mathrm{cod})_{2}$, NHC-IPr and triethylsilane in THF following the general procedure described above afforded 3d in 75\% yield and 95\% enantiomeric excess as determined by chiral HPLC. The absolute configuration of the stereocenter was assigned as $R$ in analogy to 3a and $\mathbf{3 j}$ whose configuration were established by Mosher's ester analysis

${ }^{1} \mathrm{H}$ NMR (400 MHz, $\mathrm{CDCl}_{3}, \delta$ ): 7.28 (d, $\left.J=8.8 \mathrm{~Hz}, 2 \mathrm{H}\right), 6.87(\mathrm{~d}, J=8.4 \mathrm{~Hz}, 2 \mathrm{H}), \quad 5.73$ (s, 1H), 5.23 (t, $J=7.2 \mathrm{~Hz}, 1 \mathrm{H}), 3.82$ (s, 3H), 2.26 (q, $J=7.6 \mathrm{~Hz}, 2 \mathrm{H}), 2.05(\mathrm{~m}, 1 \mathrm{H}), 1.76$ (m, 1H), 1.50 (sextet, $J=7.2 \mathrm{~Hz}, 2 \mathrm{H}), 1.40-1.15(\mathrm{~m}, 4 \mathrm{H}), 1.01(\mathrm{t}, J=7.2 \mathrm{~Hz}, 3 \mathrm{H}), 0.98$ $(\mathrm{t}, \mathrm{J}=8.0 \mathrm{~Hz}, 9 \mathrm{H}), 0.84(\mathrm{t}, J=7.0,3 \mathrm{H}), 0.64(\mathrm{q}, J=7.6 \mathrm{~Hz}, 6 \mathrm{H})$.

${ }^{13} \mathrm{C} \mathrm{NMR}\left(100 \mathrm{MHz}, \mathrm{CDCl}_{3}, \delta\right): 158.3,142.1,136.7,126.7,125.1,113.4,71.0,55.4,31.0$, $30.3,29.6,23.6,22.9,14.33,14.28,7.1,5.1$.

IR (NaCl, thin film): 2956, 2875, 1510, 1464, 1246, 1071, 741.

$[\alpha]_{\mathrm{D}}^{20}-67.5^{\circ}\left(\mathrm{c} 1.14, \mathrm{CHCl}_{3}\right)$

Chiral HPLC analysis: Analysis was performed on the corresponding free alcohol, obtained by the deprotection of 3d (TBAF, THF): (Chiralcel OD, hexanes: 2-propanol, 99:1, $1.0 \mathrm{~mL} / \mathrm{min}): \mathrm{t}_{\mathrm{R}}(R)=14.3 \mathrm{~min} ; \mathrm{t}_{\mathrm{R}}(S)=17.0 \mathrm{~min}$.

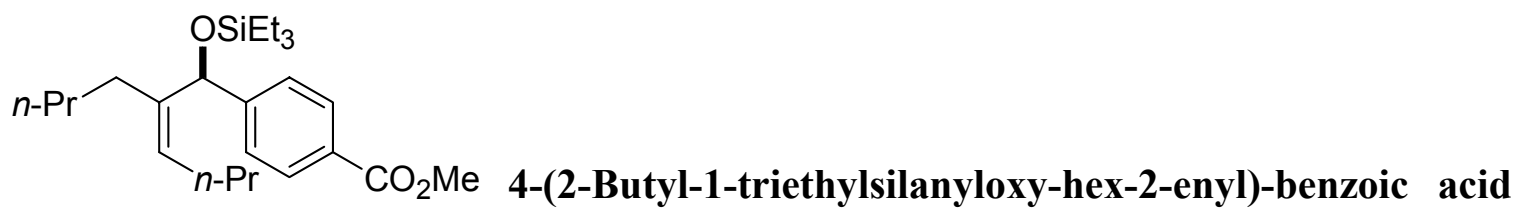

methyl ester (3e). The reaction of (aS)-nona-4,5-diene (2a) $(82 \mu \mathrm{L}, 0.5 \mathrm{mmol})$ and methyl 4-formylbenzoate $(246 \mu \mathrm{L}, 1.5 \mathrm{mmol})$ with $\mathrm{Ni}(\operatorname{cod})_{2}$, NHC-IPr and triethylsilane in THF following the general procedure described above afforded $3 \mathbf{e}$ in $56 \%$ yield (co-eluted with a small amount of homoallylic alcohol minor products) and $95 \%$ ee as determined by chiral HPLC. The absolute configuration of the stereocenter was assigned as $R$ in analogy to $\mathbf{3 a}$ and $\mathbf{3 j}$ whose configuration were established by Mosher's ester analysis. 
${ }^{1} \mathrm{H}$ NMR (500 MHz, $\left.\mathrm{CDCl}_{3}, \delta\right): 7.98(\mathrm{~d}, J=7.5 \mathrm{~Hz}, 2 \mathrm{H}), 7.43(\mathrm{~d}, J=8.0,2 \mathrm{H}), 5.79$ (s, 1H), 5.26 (t, $J=7.0 \mathrm{~Hz}, 1 \mathrm{H}), 3.90(\mathrm{~s}, 3 \mathrm{H}), 2.28(\mathrm{q}, J=7.1 \mathrm{~Hz}, 2 \mathrm{H}), 1.95(\mathrm{~m}, 1 \mathrm{H}), 1.72$ $(\mathrm{m}, 1 \mathrm{H}), 1.55$ (sextet, $J=7.0 \mathrm{~Hz}, 2 \mathrm{H}), 1.30-1.10(\mathrm{~m}, 4 \mathrm{H}), 1.01(\mathrm{t}, J=7.0 \mathrm{~Hz}, 3 \mathrm{H}), 0.96$ (t, $J=7.6 \mathrm{~Hz}, 9 \mathrm{H}), 0.79(\mathrm{t}, J=7.3 \mathrm{~Hz}, 3 \mathrm{H}), 0.63(\mathrm{q}, J=7.9 \mathrm{~Hz}, 6 \mathrm{H})$.

${ }^{13} \mathrm{C}$ NMR (125 MHz, $\left.\mathrm{CDCl}_{3}, \delta\right): 167.4,150.1,141.3,129.4,128.5,126.1,125.6,71.2$, $52.2,31.0,30.4,29.6,23.5,22.8,14.3,14.2,7.06,5.01$.

IR (NaCl, thin film): 2956, 1727, 1277, 1075, 1018, 743.

HRMS-ESI (m / z): [M + Na $]^{+}$calcd for $\mathrm{C}_{24} \mathrm{H}_{40} \mathrm{O}_{3} \mathrm{Si}$, 427.264; found, 427.266.

$[\alpha]_{\mathrm{D}}^{20}-108.6^{\circ} \quad\left(\mathrm{c} 1.28, \mathrm{CHCl}_{3}\right)$

Chiral HPLC analysis: Analysis was performed on the corresponding free alcohol, obtained by the deprotection of 3e (TBAF, THF): (Chiralcel OD, hexanes: 2-propanol, 95:5, $1.0 \mathrm{~mL} / \mathrm{min}): \mathrm{t}_{\mathrm{R}}(R)=7.5 \mathrm{~min} ; \mathrm{t}_{\mathrm{R}}(S)=19.7 \mathrm{~min}$.

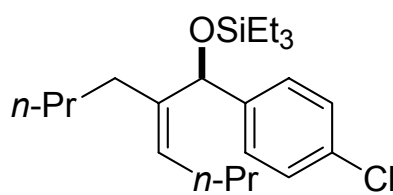

[2-Butyl-1-(4-chloro-phenyl)-hex-2-enyloxy]-triethyl- silane (3f). The reaction of (aS)-nona-4,5-diene (2a) (82 $\mu \mathrm{L}, 0.5 \mathrm{mmol})$ and $p$-chlorobenzaldehyde solution $\left(211 \mu \mathrm{L}\right.$ aldehyde, $1.5 \mathrm{mmol}$ in $1 \mathrm{~mL}$ THF) with $\mathrm{Ni}(\mathrm{cod})_{2}$, NHC-IPr and triethylsilane in THF following the general procedure described above yielded $\mathbf{3 f}$ in $65 \%$ yield and $1 \%$ of dechlorinated product, ie, 3a (total $66 \%$ isolated yield, ratio of $\mathbf{3 f}: \mathbf{3 a}$ in crude NMR is $94: 6$ ) and $95 \%$ ee as determined by chiral HPLC. The absolute configuration of the stereocenter was assigned as $R$ in analogy to $\mathbf{3 a}$ and $\mathbf{3 j}$ whose configuration were established by Mosher's ester analysis.

${ }^{1} \mathrm{H}$ NMR (400 MHz, $\left.\mathrm{CDCl}_{3}, \delta\right): 7.4-7.2(\mathrm{~m}, 4 \mathrm{H}), 5.73(\mathrm{~s}, 1 \mathrm{H}), 5.26(\mathrm{t}, J=7.0 \mathrm{~Hz}, 1 \mathrm{H})$, $2.27(\mathrm{q}, \mathrm{J}=7.3 \mathrm{~Hz}, 2 \mathrm{H}), 2.00(\mathrm{~m}, 1 \mathrm{H}), 1.72(\mathrm{~m}, 1 \mathrm{H}), 1.51$ (sextet, $J=7.4 \mathrm{~Hz}, 2 \mathrm{H}), 1.40-$ $1.10(\mathrm{~m}, 4 \mathrm{H}), 1.02(\mathrm{t}, J=7.3 \mathrm{~Hz}, 3 \mathrm{H}), 0.97$ (t, $J=7.8 \mathrm{~Hz}, 9 \mathrm{H}), 0.83$ (t, $J=7.3 \mathrm{~Hz}, 3 \mathrm{H})$, $0.64(\mathrm{q}, J=8.0 \mathrm{~Hz}, 6 \mathrm{H})$.

${ }^{13} \mathrm{C}$ NMR (100 MHz, $\left.\mathrm{CDCl}_{3}, \delta\right): 143.2,141.5,132.2,128.1,127.1,125.8,70.9,31.0$, $30.4,29.6,23.6,22.9,14.3,14.2,7.1,5.1$.

IR (NaCl, thin film): 2957, 1488, 1074, 1014, 726.

HRMS-ESI (m / z): $[\mathrm{M}+\mathrm{Na}]^{+}$calcd for $\mathrm{C}_{22} \mathrm{H}_{37} \mathrm{OClSi}$, 403.219; found, 403.220. $[\alpha]^{20}{ }_{\mathrm{D}}-88.9^{\circ}\left(\mathrm{c} 1.17, \mathrm{CHCl}_{3}\right)$ 
Chiral HPLC analysis: Analysis was performed on the corresponding free alcohol, obtained by the deprotection of $\mathbf{3 f}$ (TBAF, THF): (Chiralcel OD-H, hexanes: 2-propanol, 99:1, $1.0 \mathrm{~mL} / \mathrm{min}): \mathrm{t}_{\mathrm{R}}(S)=7.4 \mathrm{~min} ; \mathrm{t}_{\mathrm{R}}(R)=8.6 \mathrm{~min}$.<smiles>C/C=C(/CC1CCCCC1)C(OCC)c1ccccc1</smiles>

(2-Cyclohexylmethyl-1-phenyl-but-2-enyloxy)-triethyl- silane (3g). The reaction of $\mathbf{2 b}(68 \mathrm{mg}, 0.5 \mathrm{mmol})$ and benzaldehyde $(152 \mu \mathrm{L}, 1.5 \mathrm{mmol})$ with $\mathrm{Ni}(\operatorname{cod})_{2}$, NHC-IPr and triethylsilane in THF following the general procedure described above afforded $\mathbf{3 g}$ in $76 \%$ isolated yield and $98 \%$ ee as determined by chiral HPLC. The absolute configuration of the stereocenter was assigned as $R$ in analogy to $\mathbf{3 a}$ and $\mathbf{3} \mathbf{j}$ whose configuration were established by Mosher's ester analysis. The olefin geometry was determined to be $\mathrm{Z}$ by a nOe experiment (see below).

${ }^{1} \mathrm{H}$ NMR (500 MHz, $\left.\mathrm{CDCl}_{3}, \delta\right): 7.35$ (d, $\left.J=7.6 \mathrm{~Hz}, 2 \mathrm{H}\right), 7.29$ (t, $\left.J=7.3 \mathrm{~Hz}, 2 \mathrm{H}\right), 7.20$ (t, $J=7.3 \mathrm{~Hz}, 1 \mathrm{H}), 5.79(\mathrm{~s}, 1 \mathrm{H}), 5.30(\mathrm{q}, J=7.0 \mathrm{~Hz}, 1 \mathrm{H}), 1.88(\mathrm{~d}, J=6.7 \mathrm{~Hz}, 3 \mathrm{H}), 1.80$ (dd, $J=6.5,14.5 \mathrm{~Hz}, 1 \mathrm{H}), 1.68(\mathrm{dd}, J=7.0,14.5 \mathrm{~Hz}), 1.64-1.54(\mathrm{~m}, 6 \mathrm{H}), 1.28-1.18(\mathrm{~m}$, $1 \mathrm{H}), 1.12-1.00(\mathrm{~m}, 3 \mathrm{H}), 0.97(\mathrm{t}, J=7.9 \mathrm{~Hz}, 9 \mathrm{H}), 0.76-0.58(\mathrm{~m}, 1 \mathrm{H}), 0.64(\mathrm{q}, J=7.9$ $\mathrm{Hz}, 6 \mathrm{H})$.

${ }^{13} \mathrm{C}$ NMR $\left(125 \mathrm{MHz}, \mathrm{CDCl}_{3}, \delta\right): 144.6,140.8,128.0,126.5,125.6,120.4,70.9,39.2$, $36.1,33.8,33.5,27.0,26.7,13.9,7.1,5.1$.

IR (NaCl, thin film): 2954, 2921, 1449, 1091, 1064, 863, 737.

HRMS-ESI (m / z): $[\mathrm{M}+\mathrm{Na}]^{+}$calcd for $\mathrm{C}_{23} \mathrm{H}_{38} \mathrm{OSi}$, 381.258; found, 381.259. $[\alpha]^{20}{ }_{\mathrm{D}}-58.0^{\circ}\left(\mathrm{c} 1.12, \mathrm{CHCl}_{3}\right)$

Chiral HPLC analysis: Analysis was performed on the corresponding free alcohol, obtained by the deprotection of $\mathbf{3 g}$ (TBAF, THF): (Chiralcel OD-H, hexanes: 2-propanol, 99:1, $1.0 \mathrm{~mL} / \mathrm{min}): \mathrm{t}_{\mathrm{R}}(S)=11.3 \mathrm{~min} ; \mathrm{t}_{\mathrm{R}}(R)=17.4 \mathrm{~min}$.

NOE DIFF experiment: Pre-saturation of the carbinol proton $(\delta 5.79 \mathrm{ppm})$ of $\mathbf{3 g}$ gave no nOe to the vinylic proton ( $\delta 5.30 \mathrm{ppm})$. A $10.7 \%$ nOe to the methyl group, however, was observed. Similarly, pre-saturation of the methyl protons $(\delta 1.88 \mathrm{ppm})$ did not show any nOe to the cyclohexyl protons. A $4.5 \%$ nOe to the carbinol proton ( $\delta 5.79 \mathrm{ppm})$, however, was observed. (see below). 

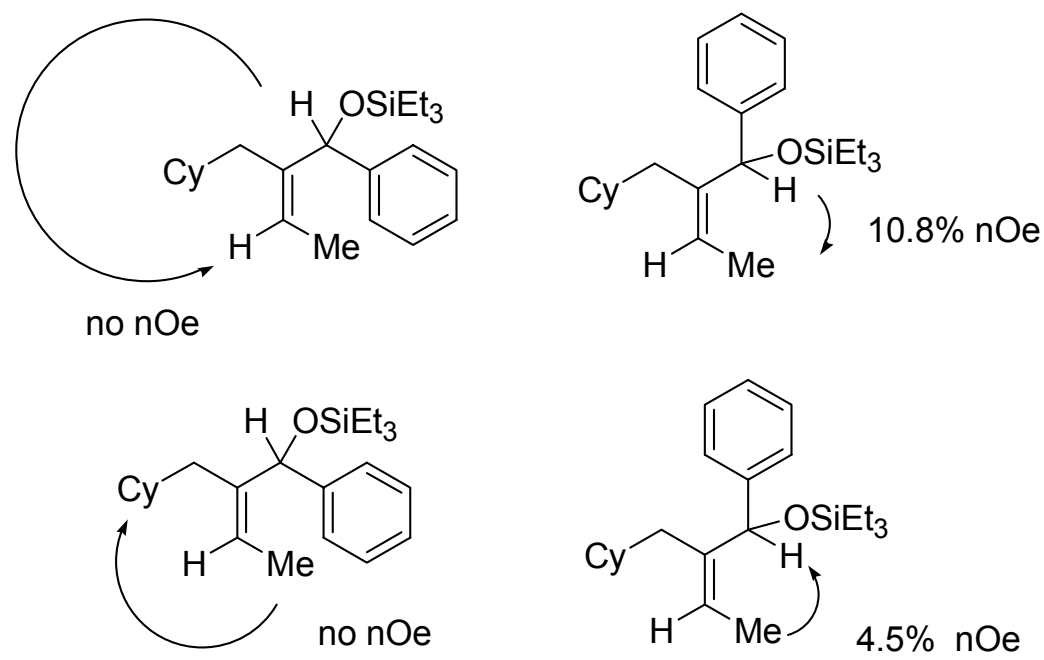

$C_{M e}^{\text {OSit-BuMe }}$

tert-Butyl-(2-cyclohexylmethyl-1-phenyl-but-2enyloxy)-dimethyl-silane (3h). The reaction of $\mathbf{2 b}(68 \mathrm{mg}, 0.5 \mathrm{mmol})$ and benzaldehyde $(152 \mu \mathrm{L}, 1.5 \mathrm{mmol})$ with $\mathrm{Ni}(\operatorname{cod})_{2}$, NHC-IPr and tert-butyldimethyl- silane in THF following the general procedure described above afforded $\mathbf{3 h}$ in $68 \%$ isolated yield and $98 \%$ ee as determined by chiral HPLC. The absolute configuration of the stereocenter was assigned as $R$ in analogy to $\mathbf{3 a}$ and $\mathbf{3} \mathbf{j}$ whose configuration were established by Mosher's ester analysis.

${ }^{1} \mathrm{H}$ NMR (400 MHz, $\mathrm{CDCl}_{3}, \delta$ ): $7.40-7.10$ (m, 5H), 5.80 (s, 1H), 5.31 (q, $J=7.0 \mathrm{~Hz}$, $1 \mathrm{H}), 1.88(\mathrm{~d}, J=7.0 \mathrm{~Hz}, 3 \mathrm{H}), 1.77$ (dd, $J=7.1,14.8 \mathrm{~Hz}, 1 \mathrm{H}), 1.66(\mathrm{dd}, J=7.0,14.6 \mathrm{~Hz}$, $1 \mathrm{H}), 1.57(\mathrm{~m}, 6 \mathrm{H}), 1.30-0.50(\mathrm{~m}, 5 \mathrm{H}), 0.96(\mathrm{~s}, 9 \mathrm{H}), 0.07$ (s, 3H), $0.06(\mathrm{~s}, 3 \mathrm{H})$.

${ }^{13} \mathrm{C}$ NMR $\left(125 \mathrm{MHz}, \mathrm{CDCl}_{3}, \delta\right): 144.5,140.5,127.9,126.5,125.6,120.5,71.1,39.1$, $35.9,33.8,33.5,26.9,26.6,26.2,18.6,13.8,-4.6,-4.8$.

IR (NaCl, thin film): 2926, 2854, 1449, 1252, 1090, 1064, 876, 835, 775, 698. HRMS-ESI (m / z): [M+ Na $]^{+}$calcd for $\mathrm{C}_{23} \mathrm{H}_{38} \mathrm{OSi}$, 381.258; found, 381.260 . $[\alpha]^{20} \mathrm{D}-55.9^{\circ}\left(\mathrm{c} 1.11, \mathrm{CHCl}_{3}\right)$

Chiral HPLC analysis: Analysis was performed $\mathbf{3 h}$ without the deprotection of the silane protected alcohol: (Chiralcel OD-H, hexanes: 2-propanol, 100:0, $0.8 \mathrm{~mL} / \mathrm{min}): \mathrm{t}_{\mathrm{R}}(R)=4.1$ 
$\min ; \mathrm{t}_{\mathrm{R}}(S)=4.4 \mathrm{~min}$.<smiles>C/C=C(/CC1CCCCC1)C(OC)c1ccccc1</smiles>

(2-Cyclohexylmethyl-1-phenyl-but-2-enyloxy)dimethyl-phenyl-silane (3i). The reaction of $\mathbf{2 b}(68 \mathrm{mg}, 0.5 \mathrm{mmol})$ and benzaldehyde $(152 \mu \mathrm{L}, 1.5 \mathrm{mmol})$ with $\mathrm{Ni}(\mathrm{cod})_{2}$, NHC-IPr and dimethylphenylsilane in THF following the general procedure described above afforded 3i in 65\% isolated yield and $98 \%$ ee as determined by chiral HPLC. The absolute configuration of the stereocenter was assigned as $R$ in analogy to $\mathbf{3 a}$ and $\mathbf{3} \mathbf{j}$ whose configuration were established by Mosher's ester analysis.

${ }^{1} \mathrm{H}$ NMR (500 MHz, $\left.\mathrm{C}_{6} \mathrm{D}_{6}, \delta\right): 7.66-7.61(\mathrm{~m}, 2 \mathrm{H}), 7.49$ (d, J= $\left.7.6 \mathrm{~Hz}, 2 \mathrm{H}\right), 7.24-7.18$ (m, 5H), 7.09 (t, $J=7.3 \mathrm{~Hz}, 1 \mathrm{H}), 5.89$ (s, 1H), 5.25 (q, $J=6.7 \mathrm{~Hz}, 1 \mathrm{H}), 2.02$ (dd, $J=7.0$, $14.7 \mathrm{~Hz}, 1 \mathrm{H}), 1.93(\mathrm{dd}, J=7.0,14.7 \mathrm{~Hz}, 1 \mathrm{H}), 1.74-1.58(\mathrm{~m}, 5 \mathrm{H}), 1.56(\mathrm{~d}, J=7.0 \mathrm{~Hz}$, $3 \mathrm{H}), 1.35(\mathrm{~m}, 1 \mathrm{H}), 1.10(\mathrm{~m}, 3 \mathrm{H}), 0.82-0.60(\mathrm{~m}, 2 \mathrm{H}), 1.57(\mathrm{~s}, 3 \mathrm{H}), 1.55(\mathrm{~s}, 3 \mathrm{H})$.

${ }^{13} \mathrm{C}$ NMR (100 MHz, $\left.\mathrm{CDCl}_{3}, \delta\right): 144.0,139.9,138.2,133.8,129.7,127.99,127.96,126.6$, $125.6,121.1,71.4,39.1,36.1,33.8,33.5,26.9,26.6,13.6,-0.9,-1.0$.

IR ( $\mathrm{NaCl}$, thin film): 2921, 2850, 1449, 1428, 1251, 1118, 1088, 1057, 881, 829, 785, 737, 698.

HRMS-ESI (m / z): [M + Na $]^{+}$calcd for $\mathrm{C}_{25} \mathrm{H}_{34} \mathrm{OSi}$, 401.227; found, 401.227. $[\alpha]^{20}{ }_{\mathrm{D}}-19.0^{\circ} \quad\left(\mathrm{c} 1.00, \mathrm{CHCl}_{3}\right)$

Chiral HPLC analysis: Analysis was performed on the corresponding free alcohol, obtained by the deprotection of 3i (TBAF, THF): (Chiralcel OD-H, hexanes: 2-propanol, 99:1, $1.0 \mathrm{~mL} / \mathrm{min}): \mathrm{t}_{\mathrm{R}}(S)=11.3 \mathrm{~min} ; \mathrm{t}_{\mathrm{R}}(R)=17.4 \mathrm{~min}$.<smiles>C/C=C(/CC(C)(C)C)C(OCC)c1ccccc1</smiles>

Triethyl-(2-ethylidene-4,4-dimethyl-1-phenyl-pentyloxy)- silane (3j). The reaction of $2 \mathbf{c}(55 \mathrm{mg}, 0.5 \mathrm{mmol})$ and benzaldehyde $(152 \mu \mathrm{L}, 1.5 \mathrm{mmol})$ with $\mathrm{Ni}(\operatorname{cod})_{2}$, NHC-IPr and triethylsilane in THF following the general procedure described above afforded $\mathbf{3 j}$ in $40 \%$ isolated yield (co-eluted with a homoallylic alcohol minor product) and 98\% ee as determined by chiral HPLC. The absolute configuration of the stereocenter was determined by Mosher's ester analysis to be $R$. 
${ }^{1} \mathrm{H}$ NMR (500 MHz, $\left.\mathrm{CDCl}_{3}, \delta\right): 7.34(\mathrm{~d}, J=7.6 \mathrm{~Hz}, 2 \mathrm{H}), 7.29(\mathrm{t}, J=7.3 \mathrm{~Hz}, 2 \mathrm{H}), 7.20(\mathrm{t}$, $J=7.3 \mathrm{~Hz}, 1 \mathrm{H}), 5.72(\mathrm{~s}, 1 \mathrm{H}), 5.46$ (q, $J=7.0 \mathrm{~Hz}, 1 \mathrm{H}), 1.91$ (d, $J=7.0 \mathrm{~Hz}, 3 \mathrm{H}), 1.86$ (d, $J$ $=14.6 \mathrm{~Hz}, 1 \mathrm{H}), 1.77(\mathrm{~d}, J=14.6 \mathrm{~Hz}, 1 \mathrm{H}), 0.95(\mathrm{t}, J=7.9 \mathrm{~Hz}, 9 \mathrm{H}), 0.80(\mathrm{~s}, 9 \mathrm{H}), 0.61(\mathrm{qd}$, $J=2.4,7.6 \mathrm{~Hz}, 6 \mathrm{H})$.

${ }^{13} \mathrm{C}$ NMR (125 MHz, $\left.\mathrm{CDCl}_{3}, \delta\right): 144.7,140.5,127.8,126.4,125.9,122.9,71.7,43.3$, 30.7, 22.7, 14.0, 6.9, 4.9.

IR (NaCl, thin film): 2954, 1463, 1091, 1065, 1006, 742.

$[\alpha]^{20}{ }_{\mathrm{D}}-29.8^{\circ}\left(\mathrm{c} 1.14, \mathrm{CHCl}_{3}\right)$

Chiral HPLC analysis: Analysis was performed on the corresponding free alcohol, obtained by the deprotection of $\mathbf{3} \mathbf{j}$ (TBAF, THF): (Chiralcel OD-H, hexanes: 2-propanol, 99:1, $1.0 \mathrm{~mL} / \mathrm{min}): \mathrm{t}_{\mathrm{R}}(S)=10.4 \mathrm{~min} ; \mathrm{t}_{\mathrm{R}}(R)=13.3 \mathrm{~min}$.

Mosher's ester analysis: (+/-)-3j was first converted into the free alcohol (TBAF, THF) and then into a pair of diastereomers of $(R)$-Mosher's esters (DCC, DMAP, $(R)$-Mosher's acid, $\left.\mathrm{CH}_{2} \mathrm{Cl}_{2}\right)^{5}$. The vinylic quartets $(\delta 5.63$ and $5.70 \mathrm{ppm})$ and the $t$-Bu singlets $(\delta 0.76$ and $0.80 \mathrm{ppm}$ ) of the two diastereomers were well resolved by ${ }^{1} \mathrm{H}$ NMR and were assigned according to the method of Mosher. ${ }^{4}$

(S)

(R)

(R)

$(\mathrm{R})$

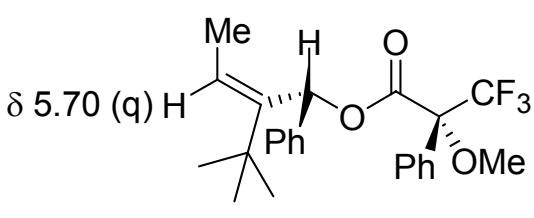

$\delta 0.80$ (s)

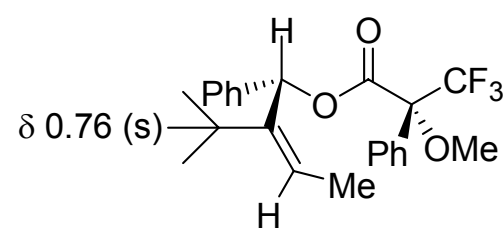

$\delta 5.63(\mathrm{q})$

The enantiomerically-enriched $\mathbf{3} \mathbf{j}$ was then converted to $(R)$-Mosher's ester using the same procedure. ${ }^{5}$ The vinylic quartet was observed at $\delta 5.64 \mathrm{ppm}$, and the t-Bu singlet was observed at $\delta 0.75 \mathrm{ppm}$. Therefore, 3a had an absolute configuration of $(R)$. 


\section{Deuterium label experiment.}

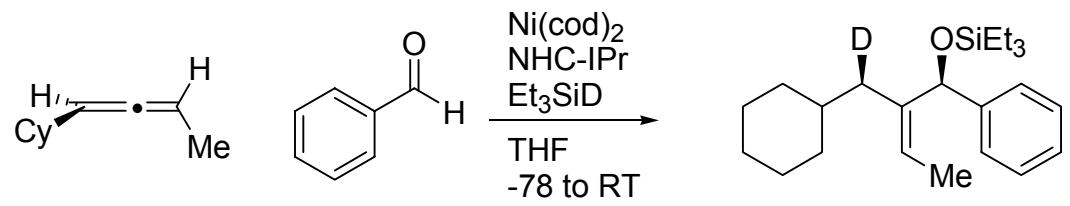

1. TBAF, THF, RT

2. $\mathrm{O}_{3} \mathrm{PPh}_{3}, \mathrm{DCM},-78$

3. $\mathrm{Pb}(\mathrm{OAc})_{4}, \mathrm{DCM}, \mathrm{RT}$
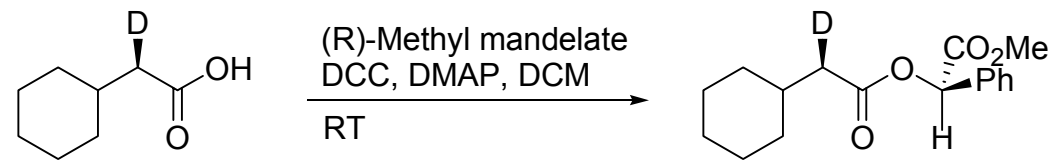

${ }^{2} \mathbf{H}-\mathbf{3 g}$ (ie, 5a) can be derivatized to a mandelic acid derivative $\mathbf{4}$ to determine the absolute configuration of the deuterated stereocenter using ${ }^{1} \mathrm{H}$ NMR by Parker's method. ${ }^{12}$ The same mandelic acid derivative was also prepared by Fleming ${ }^{13}$ and was also analyzed by the method of Parker. ${ }^{12}$<smiles>COC(=O)C([IH+])[PH2+]C(=O)OC(=O)[CH]C1CCCCC1</smiles>

(2-Cyclohexyl-acetoxy)-phenylacetic acid methyl ester $\left({ }^{1} \mathrm{H}-4\right)$. Cyclohexylacetic acid (31.3 mg, $0.22 \mathrm{mmol})$, methyl- $(R)$-mandelate (33.2 mg, $0.2 \mathrm{mmol})$, dicyclohexylcarbodiimide (61.9 $\mathrm{mg}, 0.3 \mathrm{mmol})$ and 4-(dimethylamino)-pyridine $(2.4 \mathrm{mg}$, $0.02 \mathrm{mmol})$ were mixed together and dissolved in anhydrous $\mathrm{CH}_{2} \mathrm{Cl}_{2}(2 \mathrm{~mL})$. The mixture was stirred $6 \mathrm{~h}$ at room temperature. The $\mathrm{CH}_{2} \mathrm{Cl}_{2}$ solution was filtered through a plug of silica, the silica was washed with $\mathrm{CH}_{2} \mathrm{Cl}_{2}$. The filtrate was concentrated and column chromatography afforded ${ }^{1} \mathbf{H}-4$ (45.1 mg, 78\% yield).

${ }^{1} \mathrm{H}$ NMR (400 MHz, $\left.\mathrm{C}_{6} \mathrm{D}_{6}, \delta\right): 7.46(\mathrm{~d}, J=7.2 \mathrm{~Hz}, 2 \mathrm{H}), 7.10-7.00(\mathrm{~m}, 3 \mathrm{H}), 6.09(\mathrm{~s}, 1 \mathrm{H})$, $3.18(\mathrm{~s}, 3 \mathrm{H}), 2.22(\mathrm{dd}, J=7.1,14.9 \mathrm{~Hz}, 1 \mathrm{H}), 2.12(\mathrm{dd}, J=7.1,14.9 \mathrm{~Hz}, 1 \mathrm{H}), 1.86(\mathrm{~m}$, $1 \mathrm{H}), 1.73(\mathrm{~m}, 2 \mathrm{H}), 1.60-1.40(\mathrm{~m}, 3 \mathrm{H}), 1.22-1.10(\mathrm{~m}, 2 \mathrm{H}), 1.10-0.90(\mathrm{~m}, 1 \mathrm{H}), 0.90-$ $0.75(\mathrm{~m}, 2 \mathrm{H})$.

${ }^{1} \mathrm{H}$ NMR (500 MHz, $\left.\mathrm{CDCl}_{3}, \delta\right): 7.50$ - 7.35 (m, 5H), 5.93 (s, 1H), 3.73 (s, 3H), 2.37 (dd, $J=7.0,15.0 \mathrm{~Hz}, 1 \mathrm{H}), 2.31(\mathrm{dd}, J=7.0,14.9 \mathrm{~Hz}, 1 \mathrm{H}), 1.92-1.61(\mathrm{~m}, 6 \mathrm{H}), 1.36-0.60$ $(\mathrm{m}, 5 \mathrm{H})$.

${ }^{13} \mathrm{C}$ NMR (100 MHz, $\left.\mathrm{CDCl}_{3}, \delta\right): 172.6,169.6,134.1,129.4,128.9,127.7,74.4,52.7$, $41.9,35.0,33.1,26.3,26.2$.

IR (NaCl, thin film): 2925, 2852, 1760, 1743, 1450, 1216, 1159, 1114, 1044, 734. 
<smiles>[Z11]=C([C@H](OCC)c1ccccc1)[C@@H](OCC)C1CCCCC1</smiles>

\section{(2-Cyclohexylmethyl-2-deuterio-1-phenyl-but-2-enyloxy)-}

triethyl-silane (5a / $\left.{ }^{\mathbf{2}} \mathbf{H}-3 \mathbf{g}\right)$. The reaction of $\mathbf{2 b}(68 \mathrm{mg}, 0.5 \mathrm{mmol})$ and benzaldehyde $(152 \mu \mathrm{L}, 1.5 \mathrm{mmol})$ with $\mathrm{Ni}(\mathrm{cod})_{2}$, NHC-IPr and triethylsilane-d $(239 \mu \mathrm{L}, 1.5 \mathrm{mmol})$ in THF, following the general procedure described above afforded $\mathbf{5 a} /{ }^{\mathbf{2}} \mathbf{H}-\mathbf{3 g} \quad(111 \mathrm{mg}$, $64 \%$ yield) in $98 \%$ ee as determined by chiral HPLC and $>95: 5 d r$ as determined by ${ }^{1} \mathrm{H}$ NMR.

${ }^{1} \mathrm{H}$ NMR (500 MHz, $\left.\mathrm{CDCl}_{3}, \delta\right): 7.35$ (d, $\left.J=8.0 \mathrm{~Hz}, 2 \mathrm{H}\right), 7.28(\mathrm{t}, J=7.5 \mathrm{~Hz}, 2 \mathrm{H}), 7.19$ (t, $J=7.5 \mathrm{~Hz}, 1 \mathrm{H}), 5.78(\mathrm{~s}, 1 \mathrm{H}), 5.28(\mathrm{q}, J=6.9 \mathrm{~Hz}, 1 \mathrm{H}), 1.87(\mathrm{~d}, J=7.0 \mathrm{~Hz}, 3 \mathrm{H}), 1.76$ (bd, $J=6.6 \mathrm{~Hz}, 1 \mathrm{H}), 1.62-1.52(\mathrm{~m}, 6 \mathrm{H}), 1.26-1.16(\mathrm{~m}, 1 \mathrm{H}), 1.12-1.00(\mathrm{~m}, 3 \mathrm{H}), 0.95(\mathrm{t}, J$ $=7.9 \mathrm{~Hz}, 9 \mathrm{H}), 0.76-0.58(\mathrm{~m}, 1 \mathrm{H}), 0.62(\mathrm{q}, J=7.9 \mathrm{~Hz}, 6 \mathrm{H})$.

${ }^{13} \mathrm{C}$ NMR (125 MHz, $\left.\mathrm{CDCl}_{3}, \delta\right): 144.6,140.7,127.9,126.5,125.6,120.4,70.9,38.8(\mathrm{t}, \mathrm{J}$ $=19.5 \mathrm{~Hz}), 36.0,33.8,33.5,26.9,26.6,13.9,7.1,5.1$.

IR (NaCl, thin film): 2920, 1448, 1090, 1064, 731.

HRMS-ESI (m / z): [M + Na $]^{+}$calcd for $\mathrm{C}_{23} \mathrm{H}_{37} \mathrm{DOSi}$, 382.265; found, 382.264. $[\alpha]^{20}{ }_{\mathrm{D}}-57.8^{\circ} \quad\left(\mathrm{c} 1.02, \mathrm{CHCl}_{3}\right)$

Chiral HPLC analysis: Analysis was performed on the deprotected 5a / ${ }^{\mathbf{2}} \mathbf{H}-\mathbf{3 g}$ (TBAF, THF): (Chiralcel OD-H, hexanes: 2-propanol, 99:1, $1.0 \mathrm{~mL} / \mathrm{min}): \mathrm{t}_{\mathrm{R}}(S)=11.1 \mathrm{~min}$; $\mathrm{t}_{\mathrm{R}}(R)$ $=17.3 \mathrm{~min}$.<smiles>[2H][C@@H](C(=O)[C@H](O)c1ccccc1)C1CCCCC1</smiles>

3-Cyclohexyl-3-deuterio-1-hydroxy-1-phenyl-propan-2-one (5b). 5a $/{ }^{2} \mathbf{H}-3 \mathbf{g}$ (96 mg, $0.27 \mathrm{mmol}$ ) was stirred $30 \mathrm{~min}$ in TBAF ( $1 \mathrm{~mL}, 0.5 \mathrm{mmol}, 0.5 \mathrm{M}$ in THF). The mixture was diluted in diethylether and washed with water. The ether solution was dried in $\mathrm{MgSO}_{4}$, and the solvent was removed under reduced pressure. The crude was dissolved in $\mathrm{CH}_{2} \mathrm{CL}_{2}(5 \mathrm{~mL})$ and was cooled to $-78{ }^{\circ} \mathrm{C}$. Ozone was bubbled through the solution for $20 \mathrm{~min}$, and the solution turned blue. After purging with oxygen 
(2 min) triphenylphosphine (157 $\mathrm{mg}, 0.6 \mathrm{mmol}$ in $5 \mathrm{~mL} \mathrm{CH}_{2} \mathrm{Cl}_{2}$ ) was added in one portion at $-78{ }^{\circ} \mathrm{C}$, stirred $5 \mathrm{~min}$, and warmed to room temperature. $\mathrm{CH}_{2} \mathrm{Cl}_{2}$ was removed under reduced pressure. Column chromatography first with $20 \% \mathrm{CH}_{2} \mathrm{Cl}_{2} /$ hexane removed triphenylphosphine. A gradient of $10-20 \%$ EtOAc / Hexane afforded $5 \mathbf{b}$ (62 $\mathrm{mg}, 99 \%$ yield) in $>95: 5 d r$ as determined by ${ }^{1} \mathrm{H}$ NMR.

${ }^{1} \mathrm{H}$ NMR (400 MHz, $\left.\mathrm{CDCl}_{3}, \delta\right): 7.40-7.27$ (m, 5H), $5.04(\mathrm{~d}, J=4.4 \mathrm{~Hz}, 1 \mathrm{H}), 4.43(\mathrm{~d}, J$ $=4.5 \mathrm{~Hz}, 1 \mathrm{H}), 2.14(\mathrm{dt}, J=2.0,6.9 \mathrm{~Hz}, 1 \mathrm{H}), 1.90-0.55(\mathrm{~m}, 11 \mathrm{H})$.

${ }^{13} \mathrm{C}$ NMR (100 MHz, $\mathrm{CDCl}_{3}, \delta$ ): 209.3, 138.1, 129.1, 128.8, 127.7, 80.2, 45.2 (t, $J=19.0$ $\mathrm{Hz}), 34.0,33.2,26.2,26.1,26.0$.

IR ( $\mathrm{NaCl}$, thin film): 3458, 2923, 2851, 1711, 1450, 756, 670.

$[\alpha]^{20}{ }_{\mathrm{D}}+231.7^{\circ}\left(\mathrm{c} 1.23, \mathrm{CHCl}_{3}\right)$<smiles>[2H]C(C(=O)O)C1CCCCC1</smiles>

2-Cyclohexy-(2R)-deuterio-acetic acid (5c). A $7 \mathrm{~mL}$ glass vial was charged with $5 \mathbf{b}(60 \mathrm{mg}, 0.26 \mathrm{mmol})$ and lead tetraacetate $(115 \mathrm{mg}, 0.26 \mathrm{mmol})$. The vial was purged with nitrogen, $\mathrm{CH}_{2} \mathrm{Cl}_{2}(2.5 \mathrm{~mL}$, saturated with nitrogen) was added. The reaction mixture was stirred $8 \mathrm{~h}$ at room temperature, and the $\mathrm{CH}_{2} \mathrm{Cl}_{2}$ solution was passed through a dry silica gel column (purged with argon) and eluted with $\mathrm{CH}_{2} \mathrm{Cl}_{2}$ (saturated with argon) under argon to remove benzaldehyde and other low polarity byproducts. 5c and a minor impurity were eluted with $30 \%$ ethylacetate / hexane. Column chromatography with a gradient of 5\% - 30\% EtOAc / hexane afforded 5c (14 mg, 38\% yield).

${ }^{1} \mathrm{H}$ NMR (400 MHz, $\mathrm{CDCl}_{3}, \delta$ ): $12.2-11.0$ (bs, $\left.1 \mathrm{H}\right), 2.21$ (bd, $\left.J=6.5 \mathrm{~Hz}, 1 \mathrm{H}\right), 1.85-$ $1.65(\mathrm{~m}, 6 \mathrm{H}), 1.40-0.80(\mathrm{~m}, 5 \mathrm{H})$.

${ }^{13} \mathrm{C}$ NMR (100 MHz, $\left.\mathrm{CDCl}_{3}, \delta\right): 180.0,41.8(\mathrm{t}, J=19.5 \mathrm{~Hz}), 34.8,33.2,33.1,26.3,26.2$. IR ( $\mathrm{NaCl}$, thin film): 2925, 2852, 1705, 1414, 1295. 
<smiles>CC(=O)[C@H](OC(=O)[C@@H](O)C1CCCCC1)C(C)C</smiles>

(2-Cyclohexyl-(2R)-2-deuterio-acetoxy)-phenyl-acetic acid methyl ester (4). 5c (12 mg, $0.084 \mathrm{mmol})$, methyl-( $R$ )-mandelate (21 mg, $0.09 \mathrm{mmol})$, dicyclohexylcarbodiimide (26 $\mathrm{mg}, 0.126 \mathrm{mmol})$, 4-(dimethyl)-aminopyridine (2 $\mathrm{mg}$, $0.016 \mathrm{mmol})$ was dissolved in $\mathrm{CH}_{2} \mathrm{Cl}_{2}(1.5 \mathrm{~mL})$ and stirred $12 \mathrm{~h}$ at room temperature. The crude reaction mixture was filtered through a plug of silica, and the silica was washed with $\mathrm{CH}_{2} \mathrm{Cl}_{2}$. Column chromatography in 1\% - 5\% EtOAc / hexane afforded 4 (15.6 mg, $52 \%$ yield). ${ }^{1} \mathrm{H}$ NMR indicated slight erosion of $d r(>90: 10)$ at the deuterated stereocenter as compared to $\mathbf{5 a} /{ }^{\mathbf{2}} \mathbf{H} \mathbf{- 3 g}$ before derivatization to $\mathbf{4}$. The deuterated stereocenter was assigned to be of the $R$ configuration, according to the method of Parker, ${ }^{12}$ and the analysis was consistent with Fleming's result ${ }^{13}$.<smiles>[2H][C@@H](C(=O)O[C@@H](C(=O)OC)c1ccccc1)C1CCCCC1</smiles>

(R) (Refer to ${ }^{1} \mathrm{H}$ NMRs of ${ }^{\mathbf{1}} \mathbf{H}-\mathbf{4}, \mathbf{4}$ and $\mathbf{5 d}$ for chemical shifts).

${ }^{1} \mathrm{H}$ NMR (400 MHz, $\left.\mathrm{C}_{6} \mathrm{D}_{6}, \delta\right): 7.48(\mathrm{~d}, J=6.9 \mathrm{~Hz}, 2 \mathrm{H}), 7.07(\mathrm{t}, J=6.0 \mathrm{~Hz}, 2 \mathrm{H}), 7.03(\mathrm{t}, J$ $=7.4 \mathrm{~Hz}, 1 \mathrm{H}), 6.10(\mathrm{~s}, 1 \mathrm{H}), 3.18(\mathrm{~s}, 3 \mathrm{H}), 2.20(\mathrm{dt}, J=1.7,6.9 \mathrm{~Hz}, 1 \mathrm{H}), 1.92-1.80(\mathrm{~m}$, $1 \mathrm{H}), 1.80-1.68(\mathrm{~m}, 2 \mathrm{H}), 1.61-1.42(\mathrm{~m}, 3 \mathrm{H}), 1.22-1.07(\mathrm{~m}, 2 \mathrm{H}), 1.07-0.91(\mathrm{~m}, 1 \mathrm{H})$, $0.90-0.75(\mathrm{~m}, 2 \mathrm{H})$.

${ }^{1} \mathrm{H}$ NMR (400 MHz, $\left.\mathrm{CDCl}_{3}, \delta\right): 7.50$ - 7.40 (m, 2H), $7.44-7.37$ (m, 3H), $5.93(\mathrm{~s}, 1 \mathrm{H})$, $3.73(\mathrm{~s}, 3 \mathrm{H}), 2.35(\mathrm{bd}, J=6.9 \mathrm{~Hz}, 1 \mathrm{H}), 1.90-1.60(\mathrm{~m}, 6 \mathrm{H}), 1.55-0.90(\mathrm{~m}, 5 \mathrm{H})$.

${ }^{13} \mathrm{C}$ NMR $\left(125 \mathrm{MHz}, \mathrm{CDCl}_{3}, \delta\right): 172.7,169.6,134.1,129.4,129.0,127.8,74.4,52.8$, $41.6(\mathrm{t}, J=20.0 \mathrm{~Hz}), 35.0,33.11,33.08,26.3,26.2$.

IR (NaCl, thin film): 2924, 2851, 1760, 1743, 1450, 1436, 1216, 1163. $[\alpha]^{20}{ }_{\mathrm{D}}+112.0^{\circ} \quad\left(\mathrm{c} 1.25, \mathrm{CHCl}_{3}\right)$<smiles>COC(=O)C(O)C(=O)OC(=O)C(O)c1ccccc1</smiles>

(2R)-(2-Cyclohexyl-(2)-deuterio-acetoxy)-phenyl-acetic acid methyl ester and (2S)-(2-Cyclohexyl-(2)-deuterio-acetoxy)-phenyl-acetic acid methyl ester (5d). Prepared using the same method as 4 except that (+/-)-2b was used to give a mixture of 1:1 diastereomers of $\mathbf{5 d}$. 
${ }^{1} \mathrm{H}$ NMR (400 MHz, $\left.\mathrm{C}_{6} \mathrm{D}_{6}, \delta\right): 7.48(\mathrm{~d}, J=7.2 \mathrm{~Hz}, 2 \mathrm{H}), 7.07$ (t, $\left.J=7.0 \mathrm{~Hz}, 2 \mathrm{H}\right), 7.04$ (t, $J$ $=7.1 \mathrm{~Hz}, 1 \mathrm{H}), 6.11(\mathrm{~s}, 2 \mathrm{H}), 3.18(\mathrm{~s}, 6 \mathrm{H}), 2.20(\mathrm{dt}, J=1.8,6.9 \mathrm{~Hz}, 1 \mathrm{H}), 2.12(\mathrm{dt}, J=1.8$, $7.1 \mathrm{~Hz}, 1 \mathrm{H}), 1.92-1.80(\mathrm{~m}, 1 \mathrm{H}), 1.80-1.68(\mathrm{~m}, 2 \mathrm{H}), 1.61-1.42(\mathrm{~m}, 3 \mathrm{H}), 1.22-1.07$ (m, 2H), $1.07-0.91(\mathrm{~m}, 1 \mathrm{H}), 0.90-0.75(\mathrm{~m}, 2 \mathrm{H})$.

${ }^{1} \mathrm{H}$ NMR $\left(400 \mathrm{MHz}, \mathrm{CDCl}_{3}, \delta\right): 7.50-7.40(\mathrm{~m}, 2 \mathrm{H}), 7.44-7.37$ (m, 3H), $5.93(\mathrm{~s}, 1 \mathrm{H})$, 3.73 (s, 3H), 2.35 (dt, $J=1.9,6.9 \mathrm{~Hz}, 1 \mathrm{H}), 2.30$ (bd, $J=1.8,7.0 \mathrm{~Hz}, 1 \mathrm{H}), 1.90-1.60$ (m, $6 \mathrm{H}), 1.55-0.90(\mathrm{~m}, 5 \mathrm{H})$.

${ }^{13} \mathrm{C}$ NMR $\left(125 \mathrm{MHz}, \mathrm{CDCl}_{3}, \delta\right): 172.7,169.6,134.1,129.4,129.0,127.8,74.4,52.8$, $41.6(\mathrm{t}, J=20.0 \mathrm{~Hz}), 35.0,33.11,33.08,26.3,26.2$.

IR (NaCl, thin film): 2923, 1850, 1760, 1742, 1215, 1163.

\section{References}

1. Arduengo, A. J., III; Krafczyk, R.; Schmutzler, R. Tetrahedron 1999, 55, 14523 14534.

2. Finholt, A. E.; Bond, A. C., Jr.; Wilzboch, K. E.; Schlessinger, H. I. J. Am. Chem. Soc. 1947, 69, 2692-2696.

3. Burgess, K.; Jennings, L. D. J. Am. Chem. Soc. 1991, 113, 6129-6139.

4. (a) Dale, J. A.; Dull, D. L.; Mosher, H. S. J. Org. Chem. 1969, 34, 2543-2549. (b) Dale, J. A.; Mosher, H. S. J. Am. Chem. Soc. 1973, 95, 512-519.

5. Yakelis, N. A.; Roush, W. R. J. Org. Chem. 2003, 68, 3838-3843.

6. (a) Myers, A. G.; Zheng, B. J. Am. Chem. Soc. 1996, 118, 4492-4493. (b) Myers, A. G.; Zheng, B. Org. Synth., Coll. Vol. X, 165.

7. Myers, A. G.; Zheng, B.; Movassaghi, M. J. Org. Chem. 1997, 62, 7507.

8. Eliel, E. L.; Wilen, S. H.; Mander, L. N. Stereochemistry of Organic Compounds; Wiley \& Sons: New York, 1994; pp 1091..

9. Danheiser, R. L.; Choi, Y. M.; Menichincheri, M.; Stoner, E. J. J. Org. Chem. 1993, 58, 322-327.

10. Pasto, D. J.; Brophy, J. E. J. Org. Chem. 1991, 56, 4554-4556.

11. Michael, F. E.; Duncan, A. P.; Sweeney, Z. K.; Bergman, R. G. J. Am. Chem. Soc. 2003, 125, 7184-7185.

12. (a) Brown, J. M.; Parker, D. Tetrahedron Lett. 1981, 22, 2815-2818. (b) Parker, D. J. Chem. Soc., Perkin Trans. 2 1983, 83-88.

13. Fleming, I.; Jones, G. R.; Kindon, N. D.; Landais, Y.; Leslie, C. P.; Morgan, I. T.; Peukert, S.; Sarkar, A. K. J. Chem. Soc., Perkin Trans. 1. 1996, 1171-1196. 

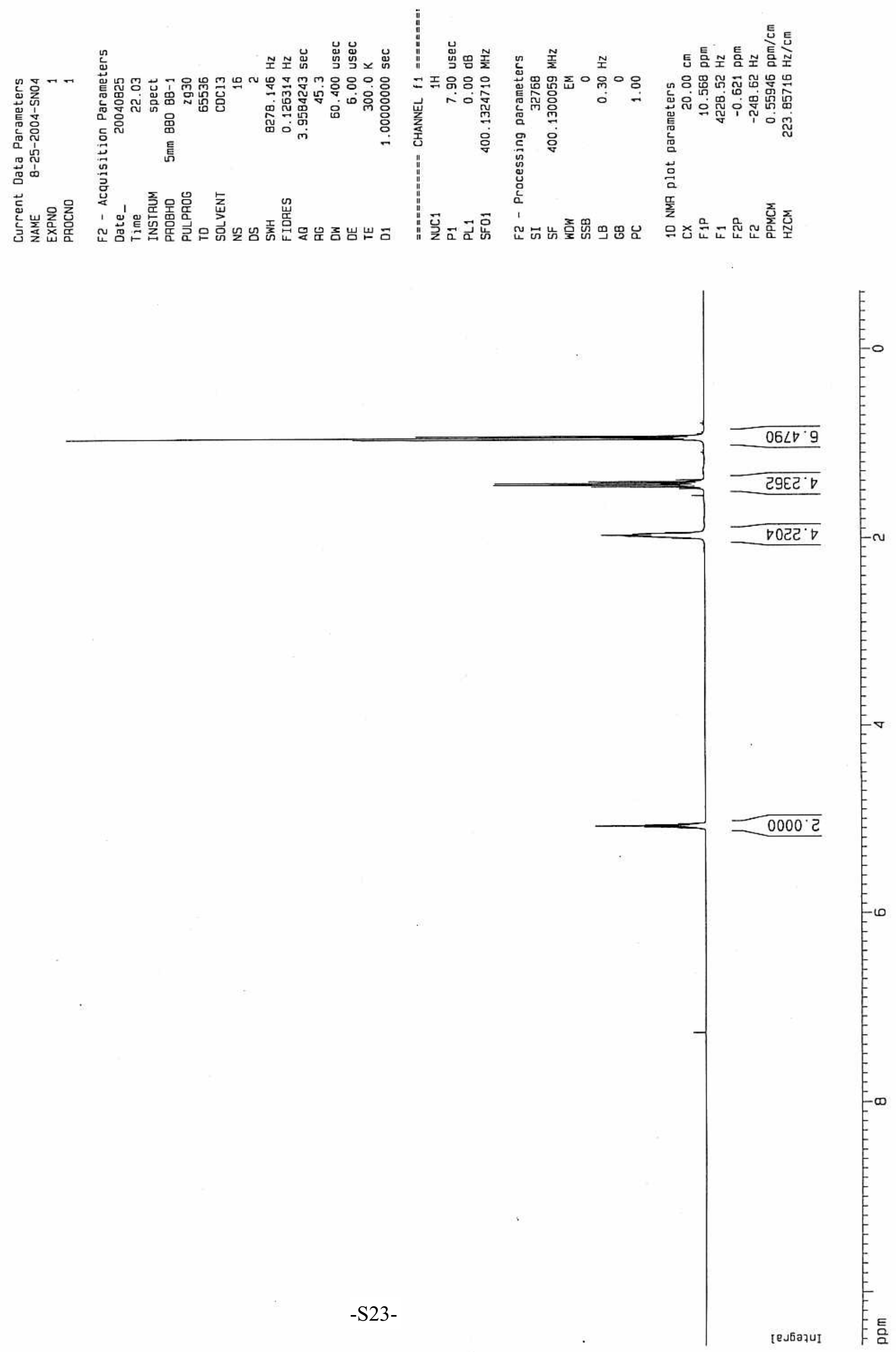


$$
1
$$



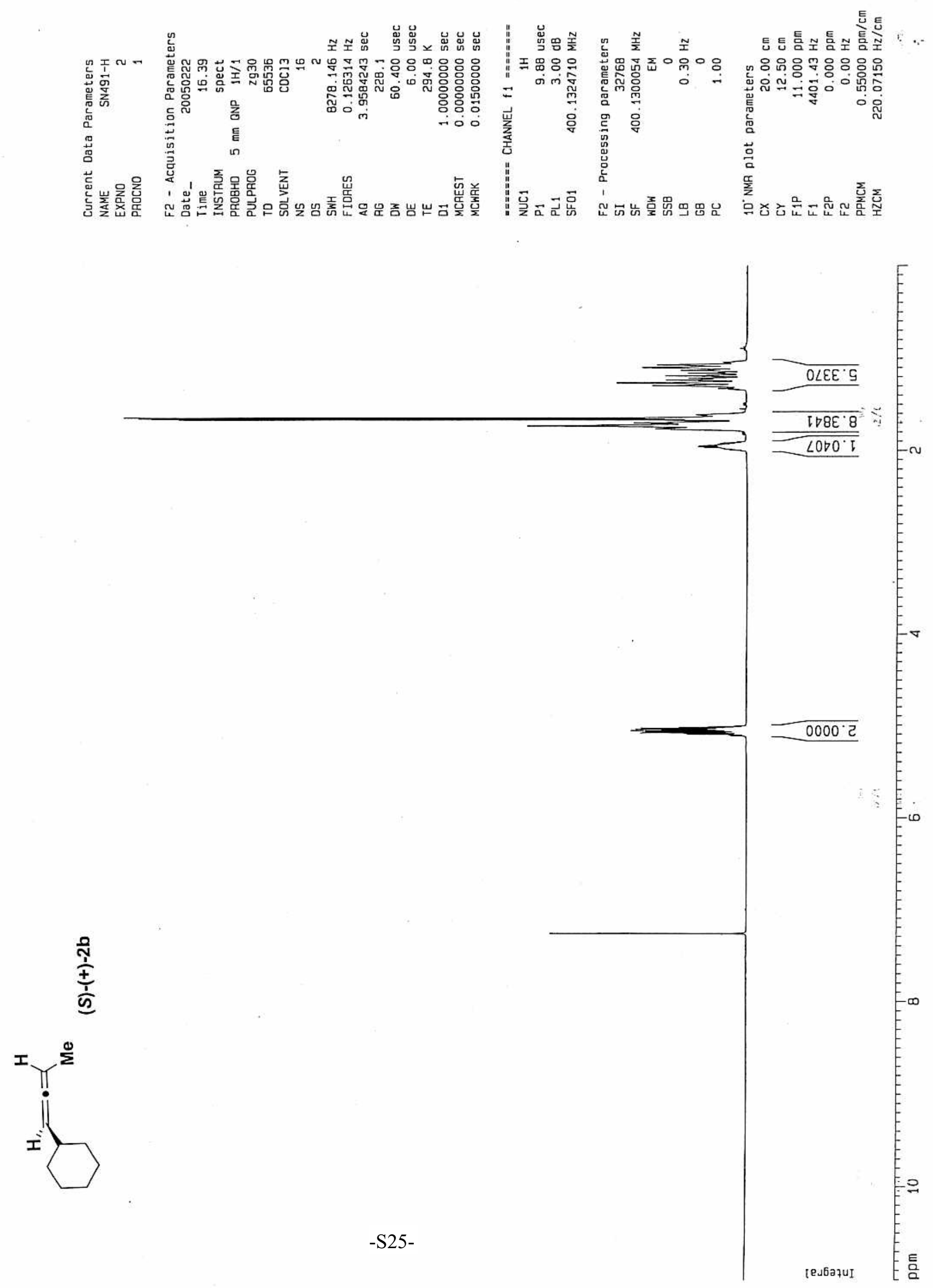
$\frac{\frac{0}{T}}{\frac{1}{5}}$

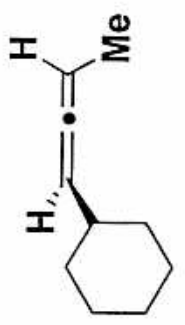



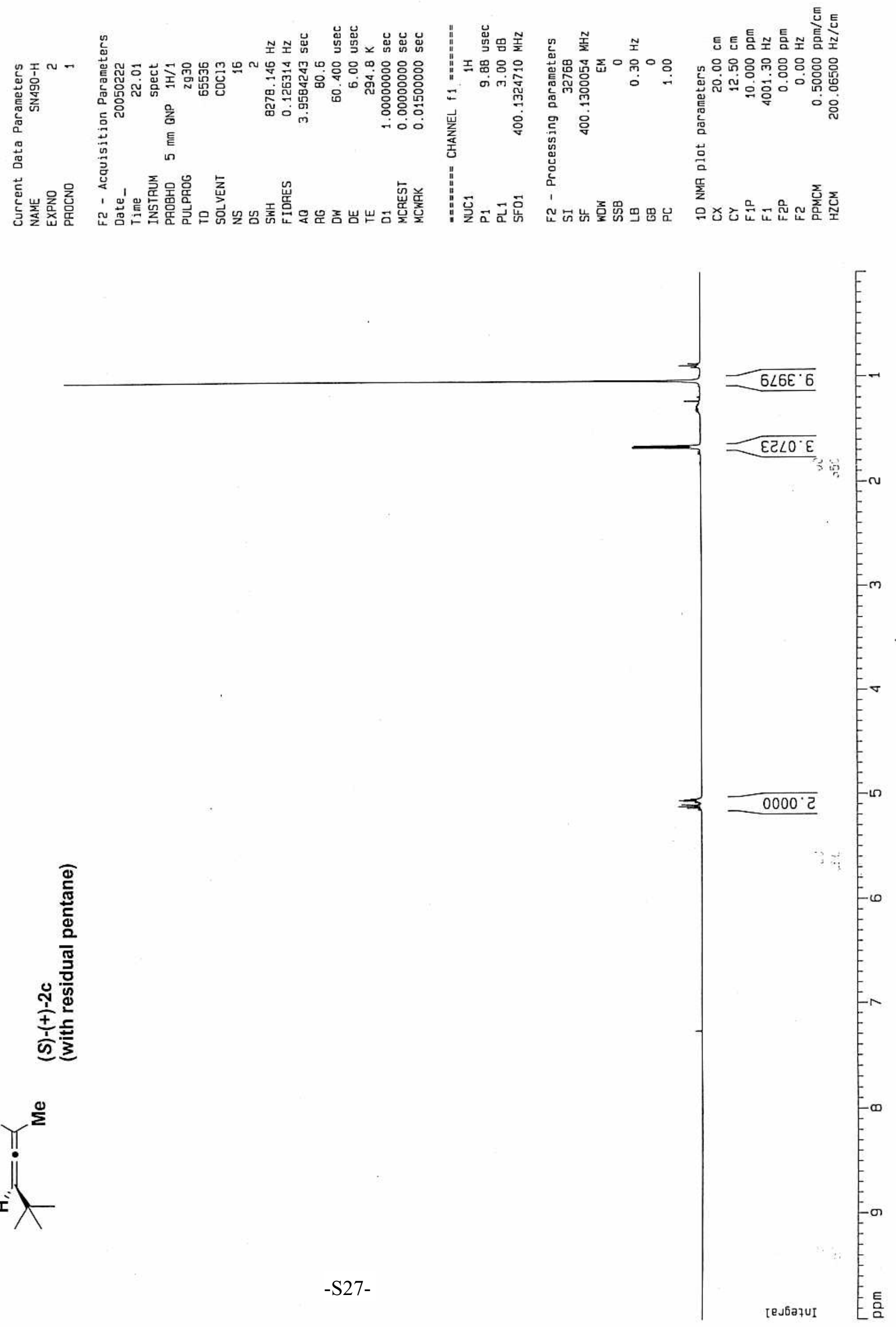

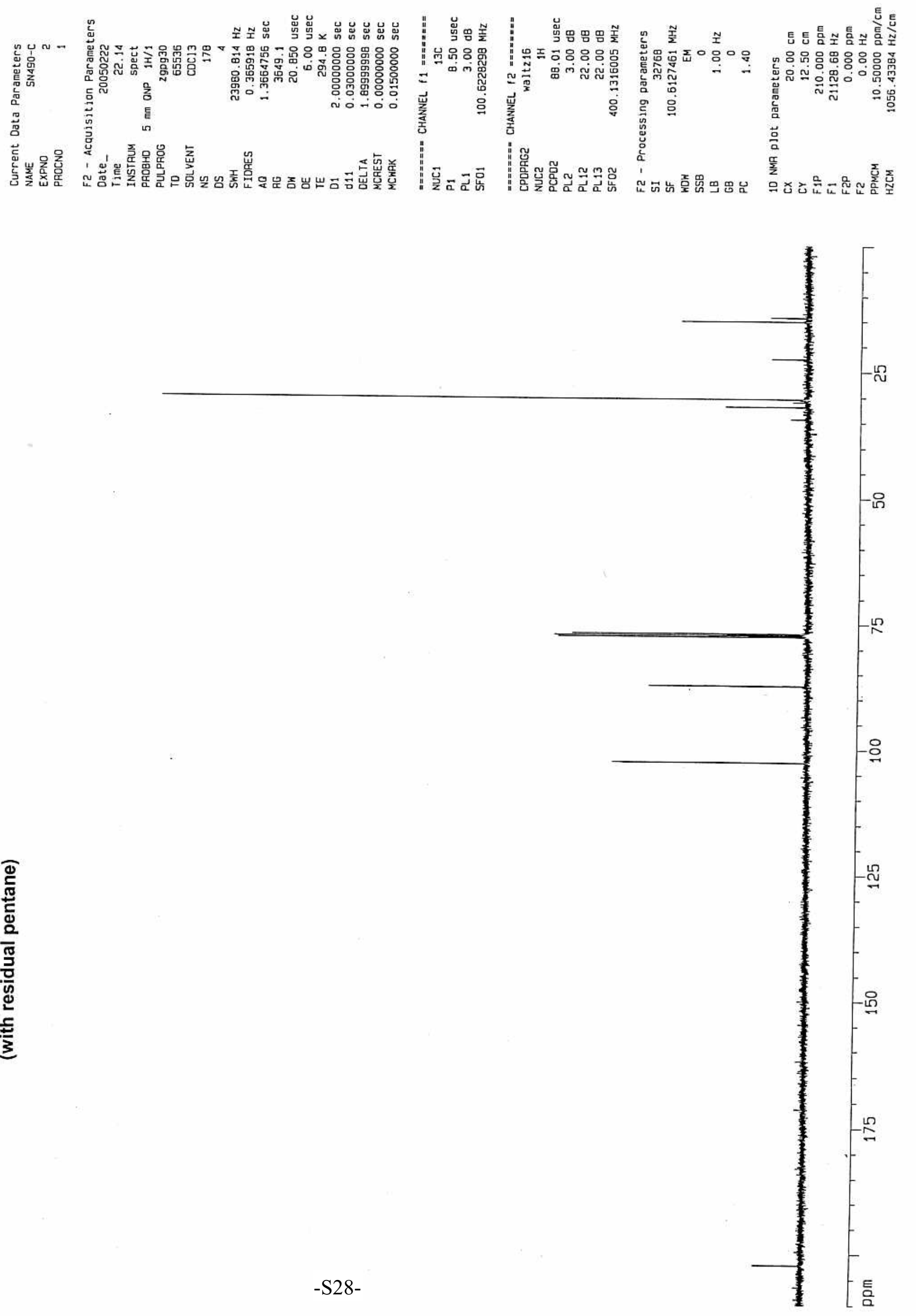


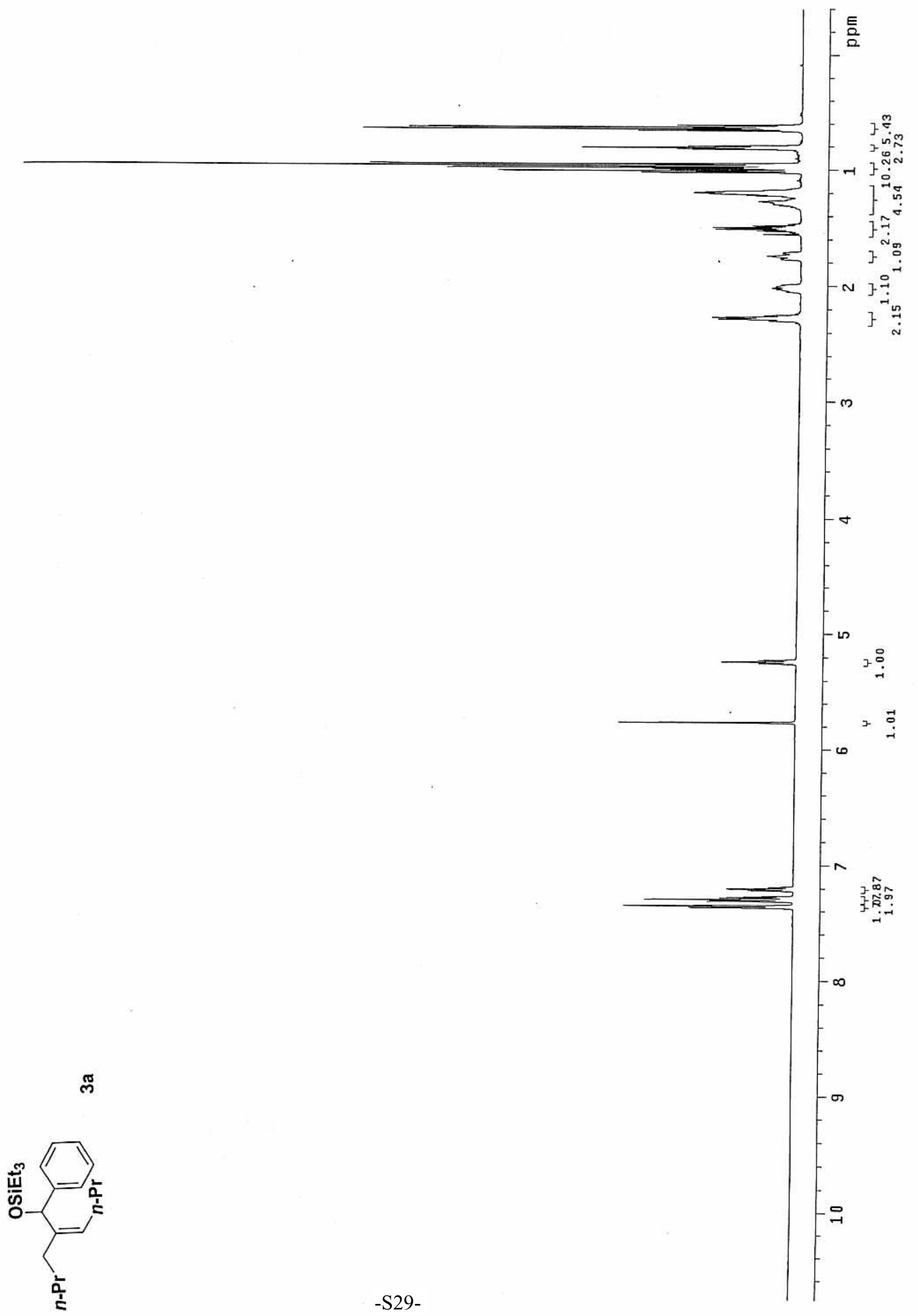




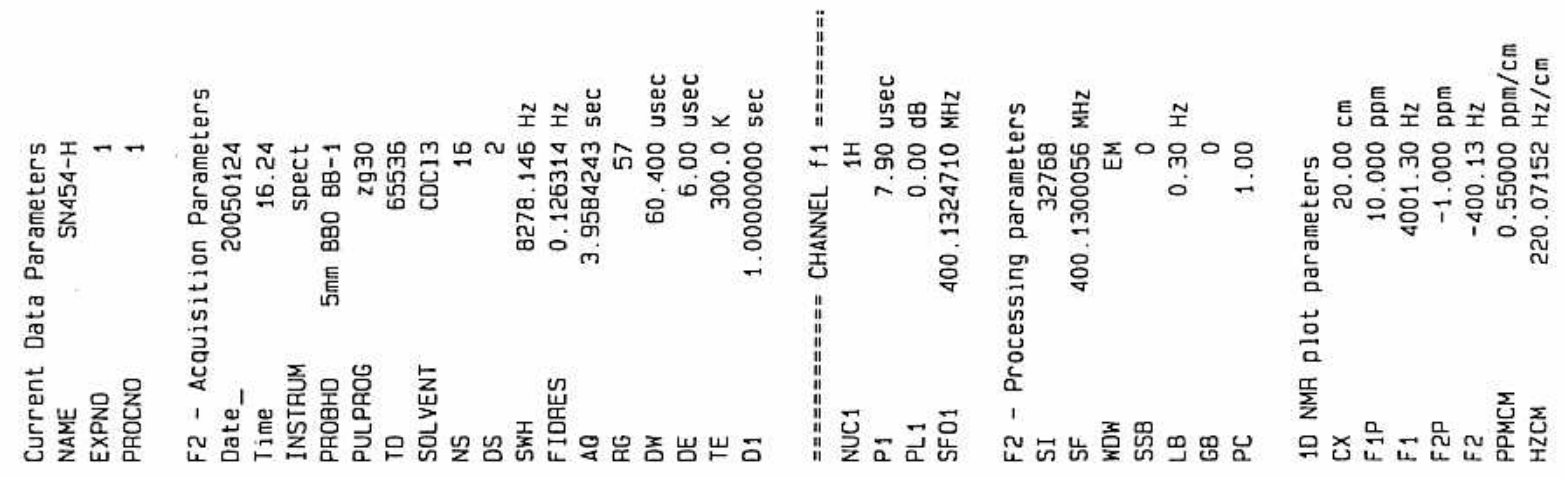

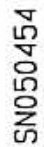

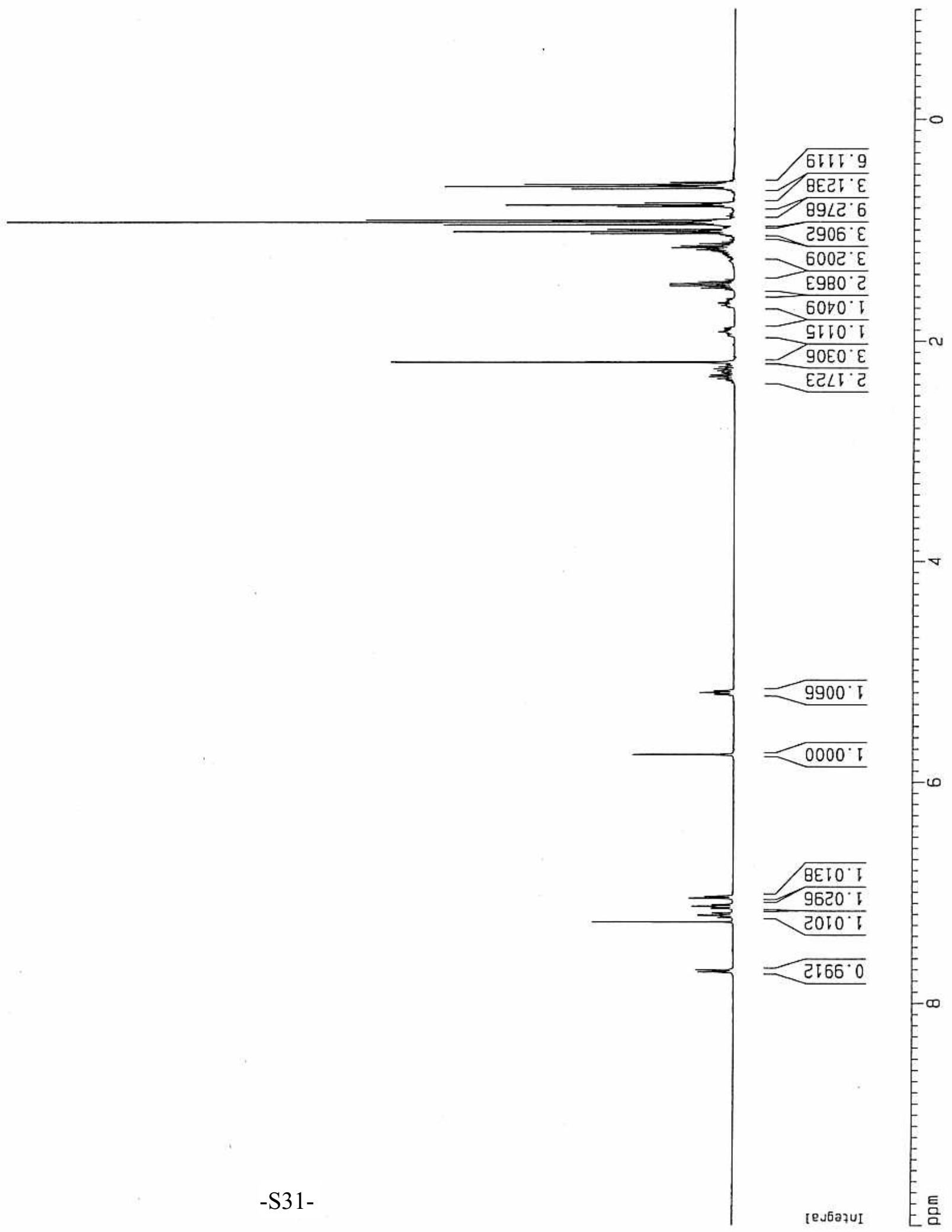




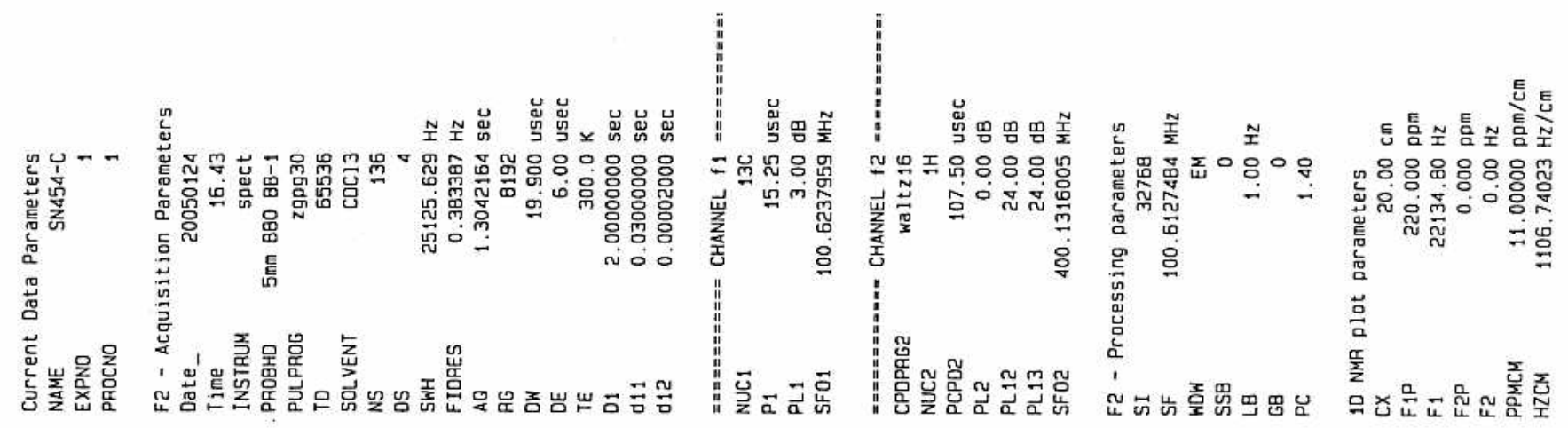

号

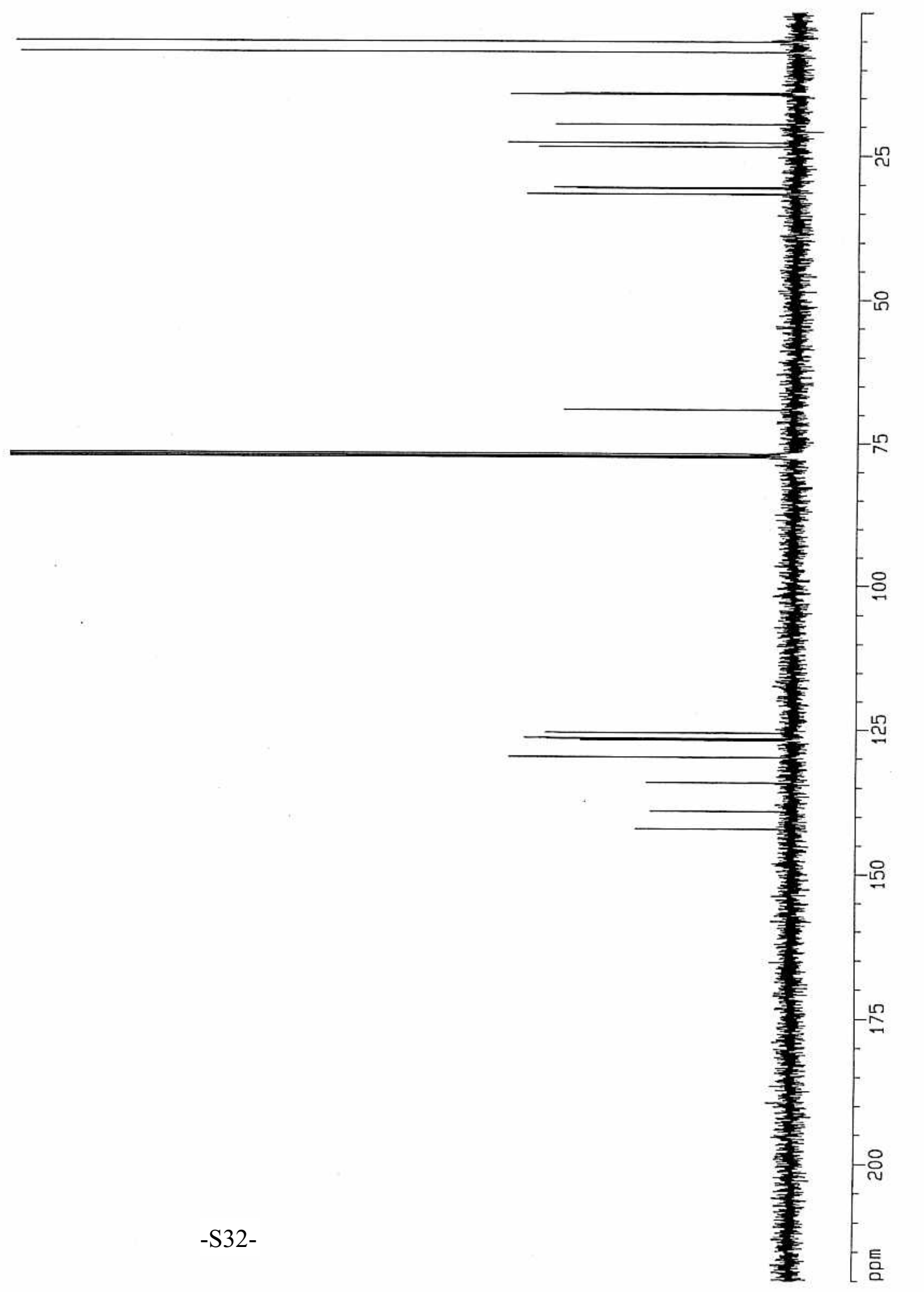




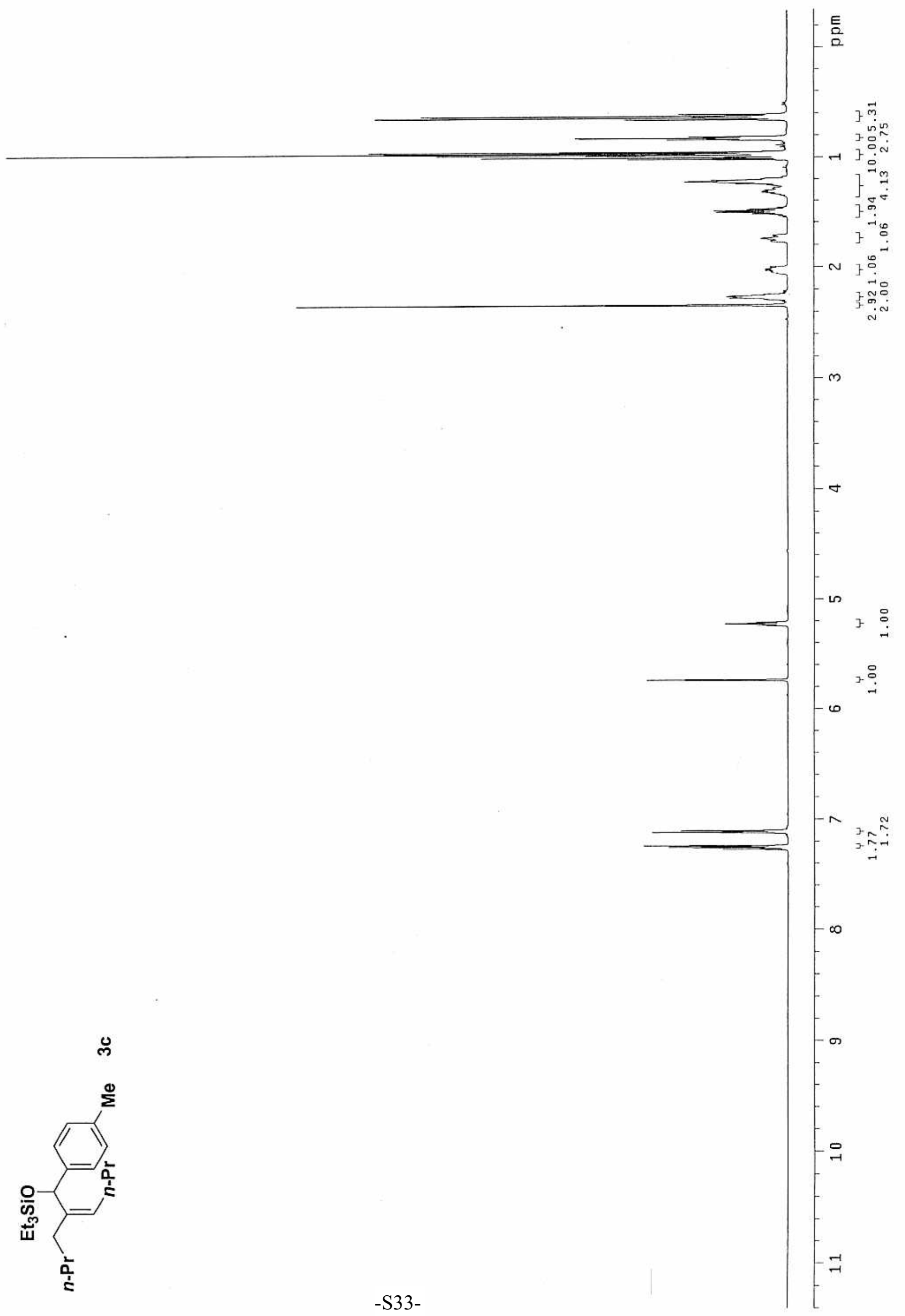




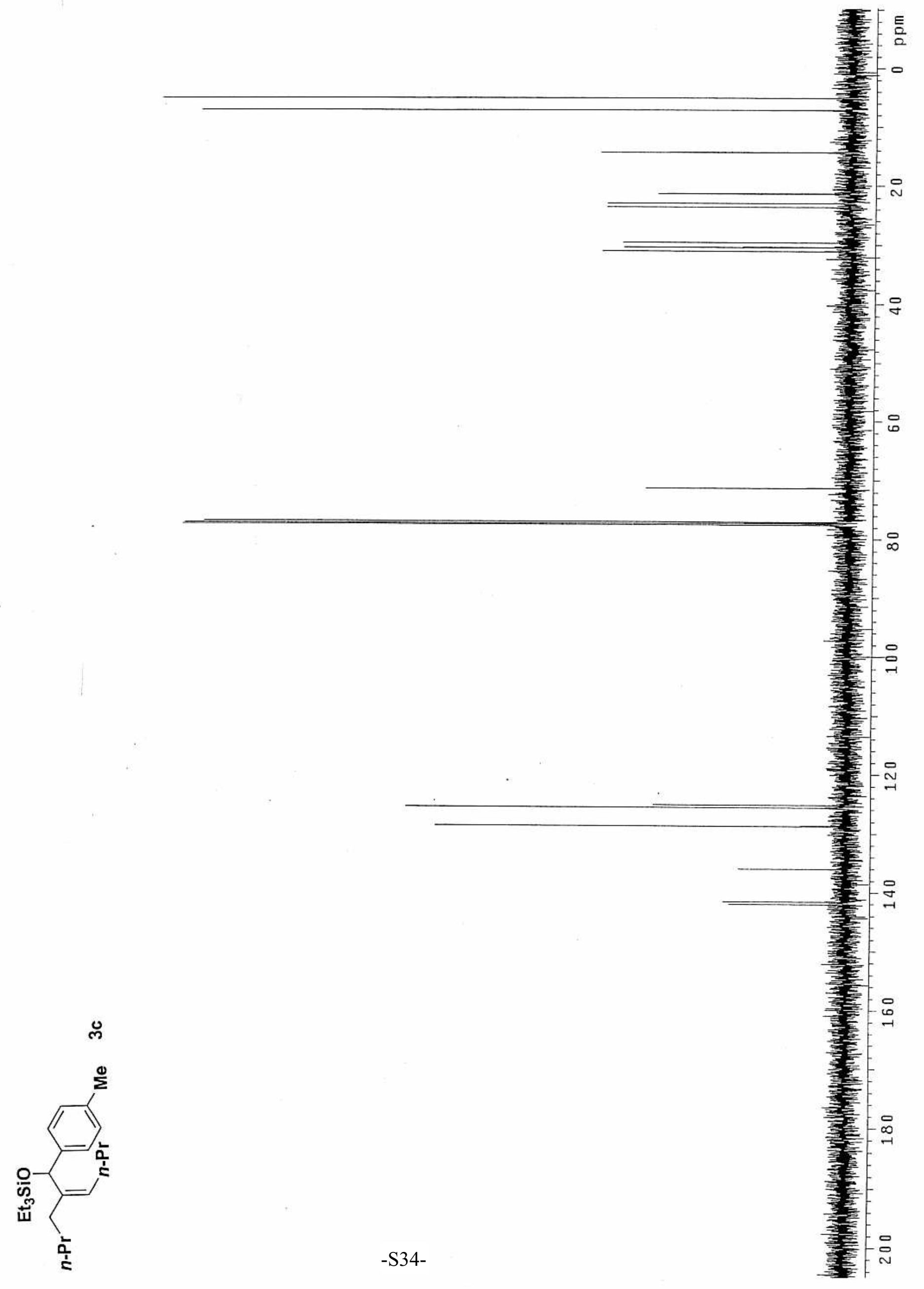



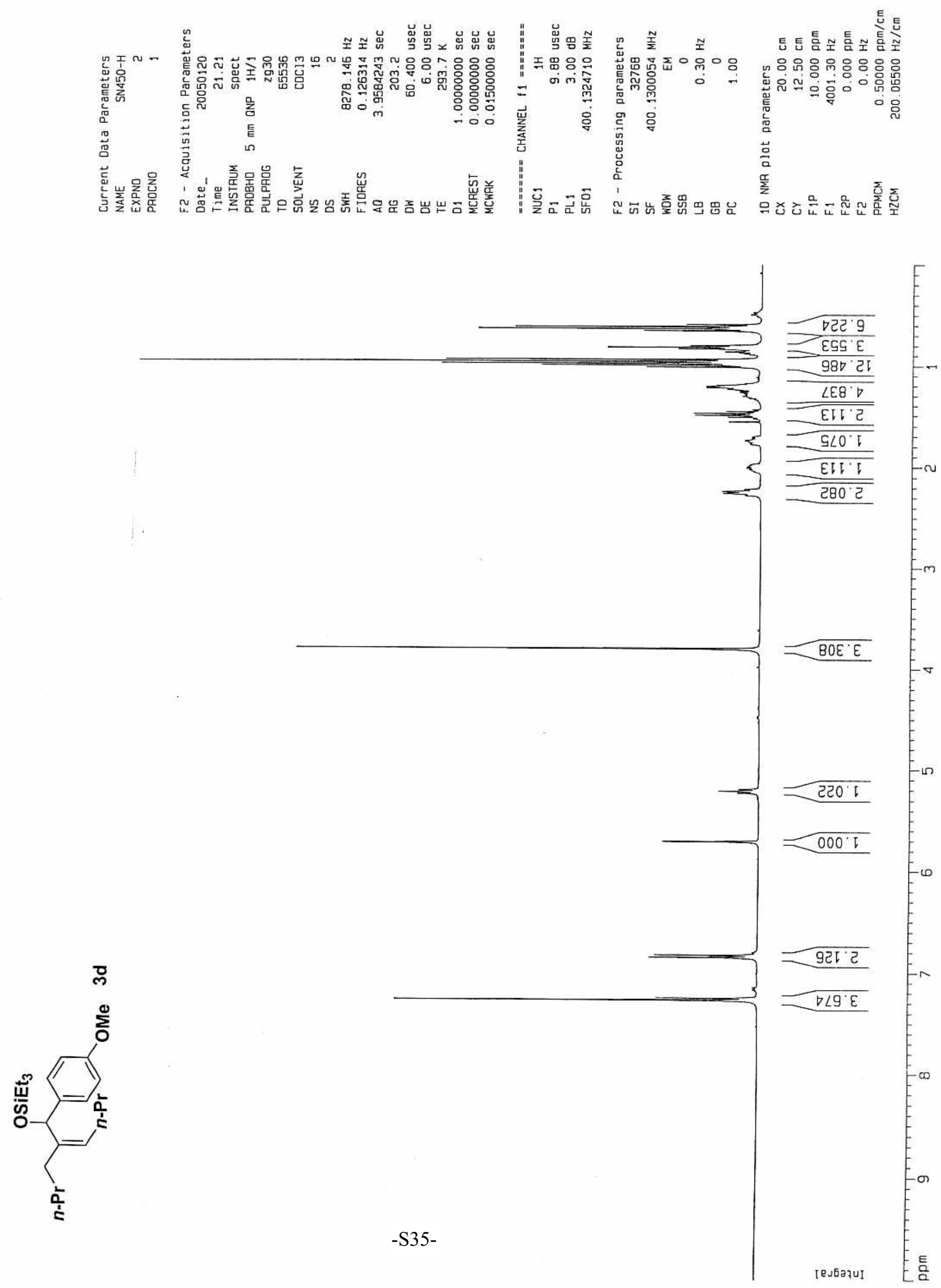


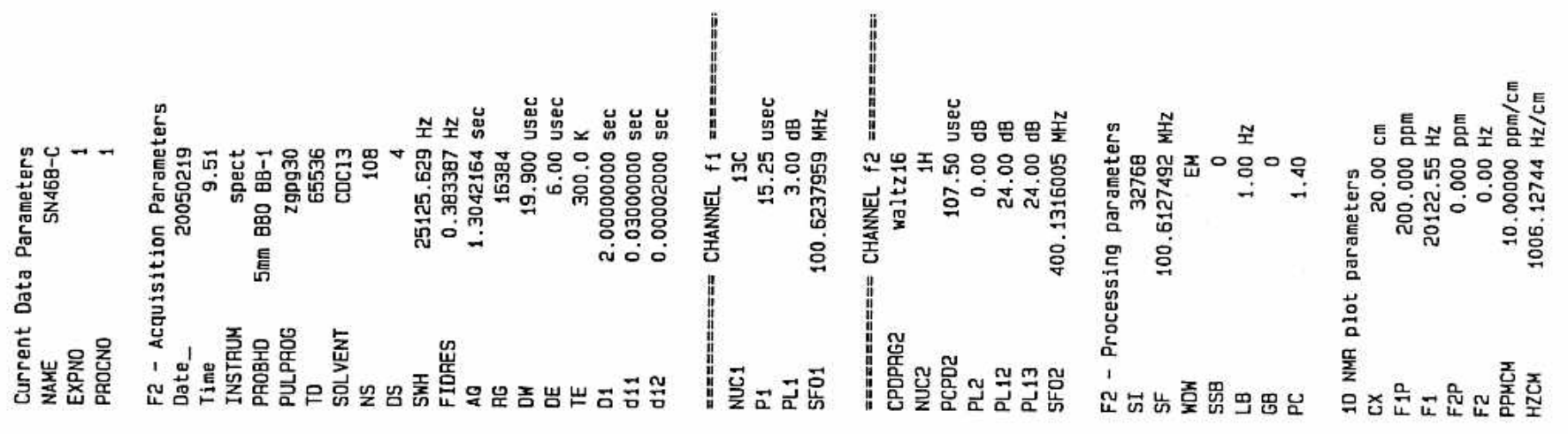

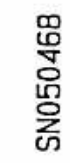

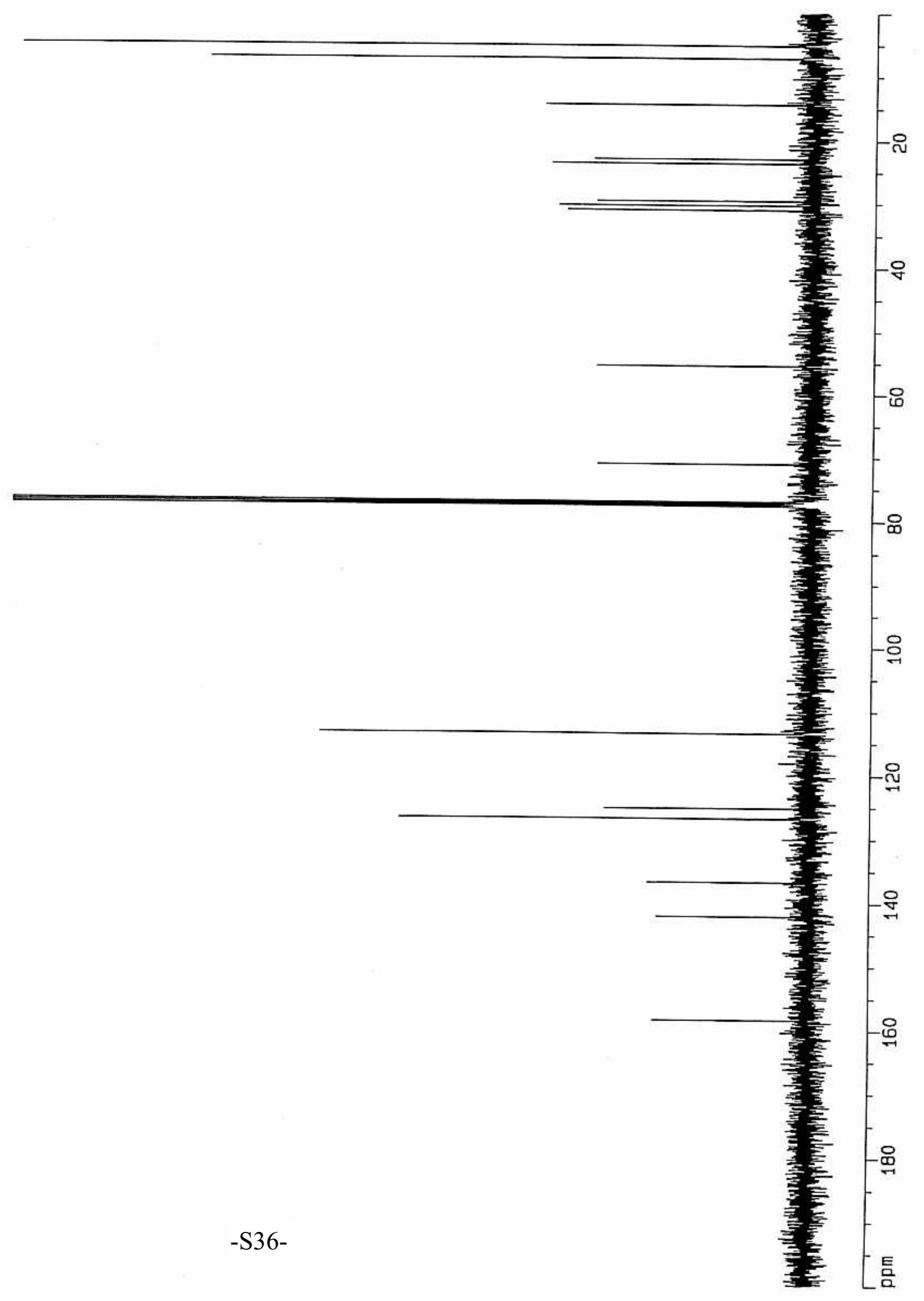




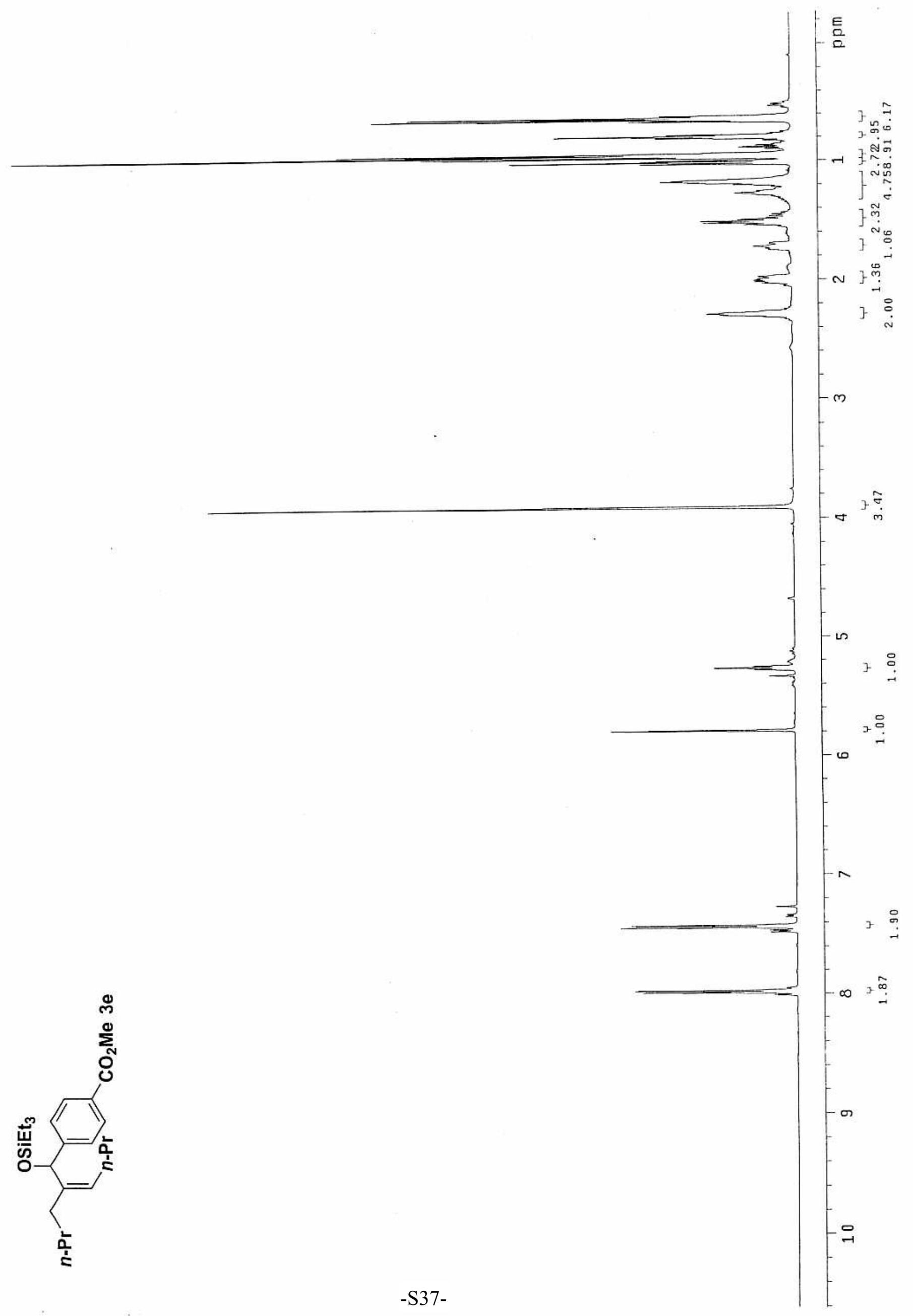




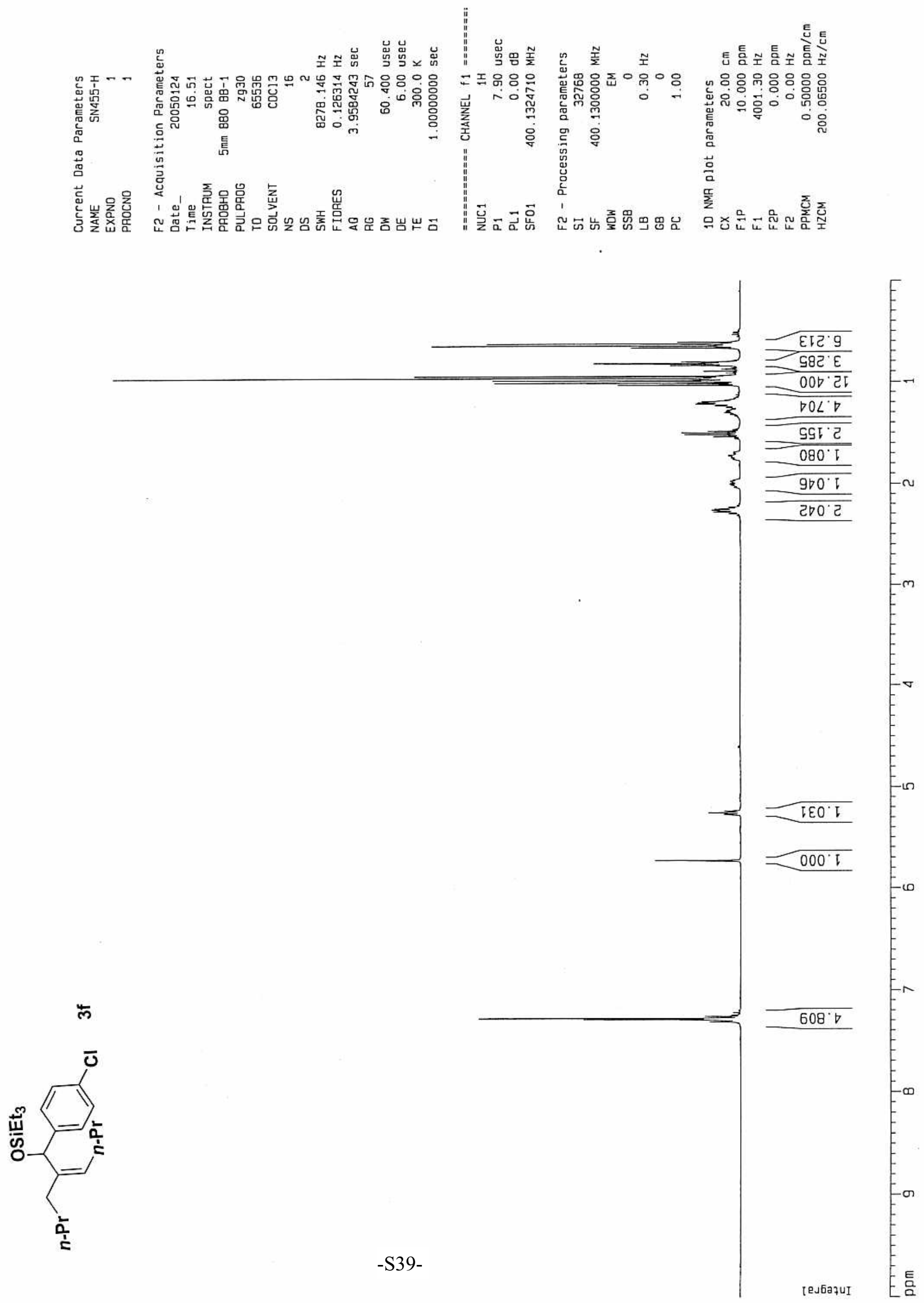
$\begin{array}{ll} & \\ & \\ & \end{array}$

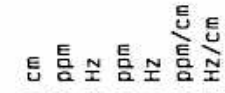

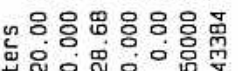

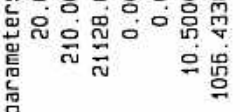
总

㖇

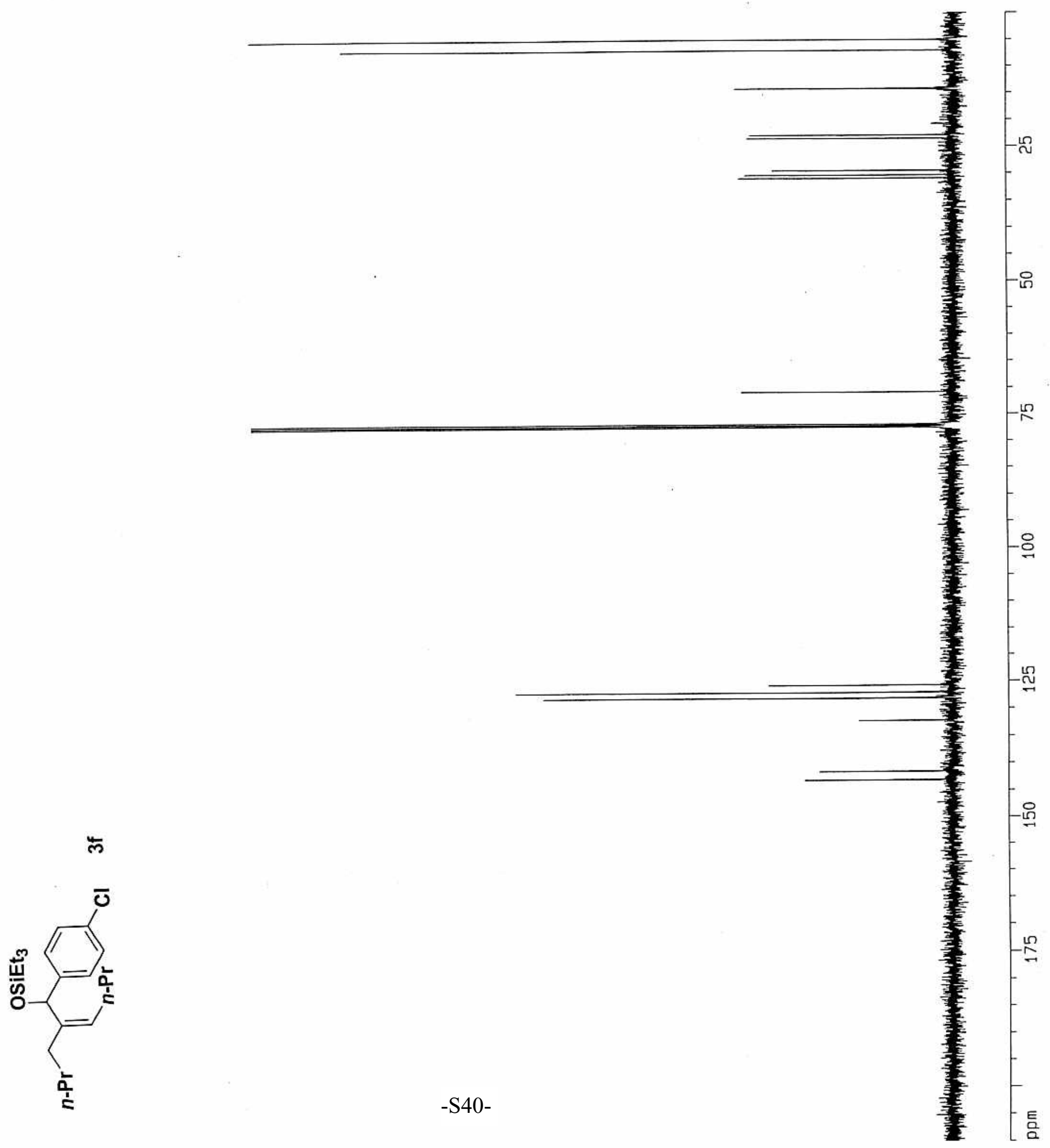




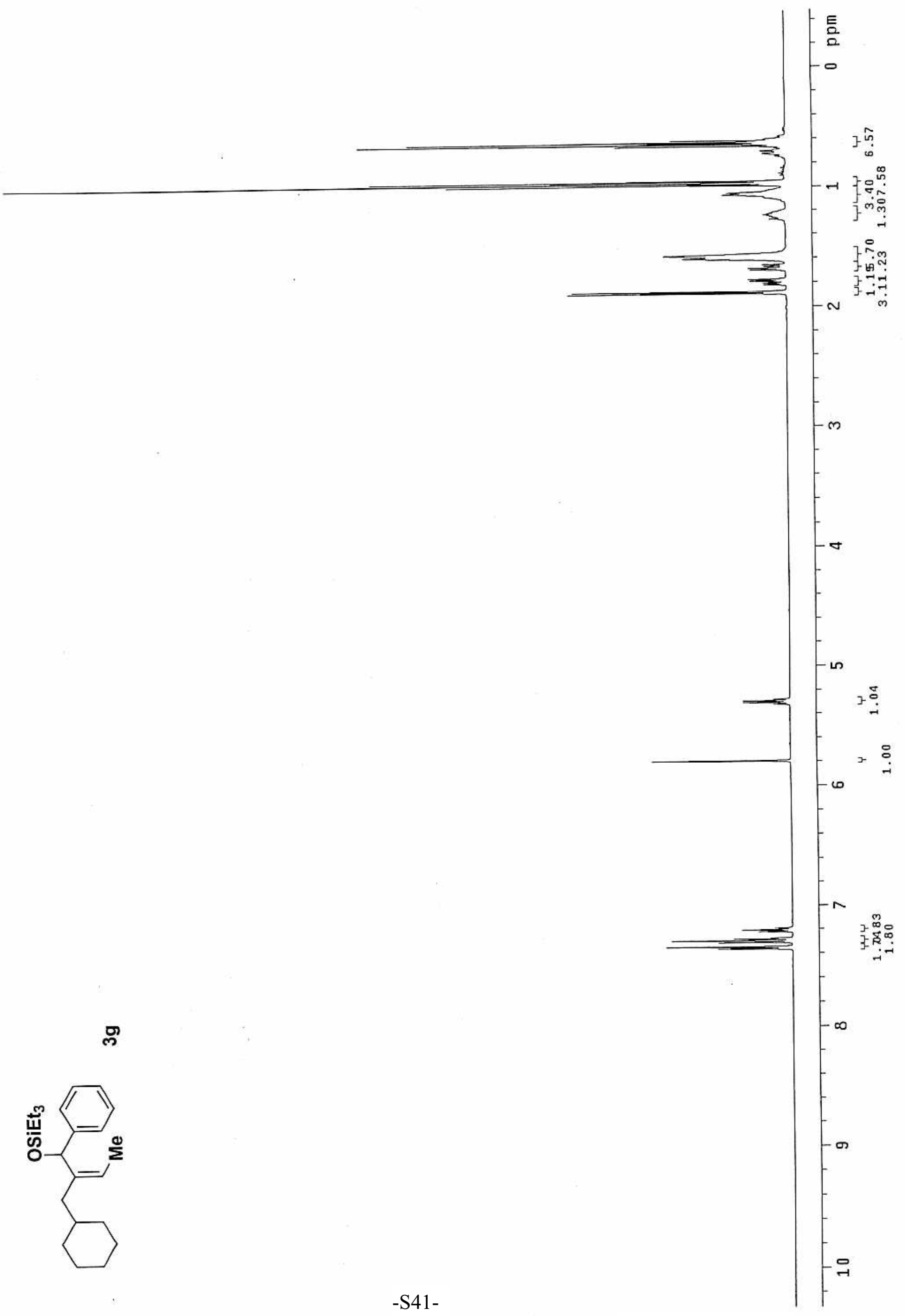




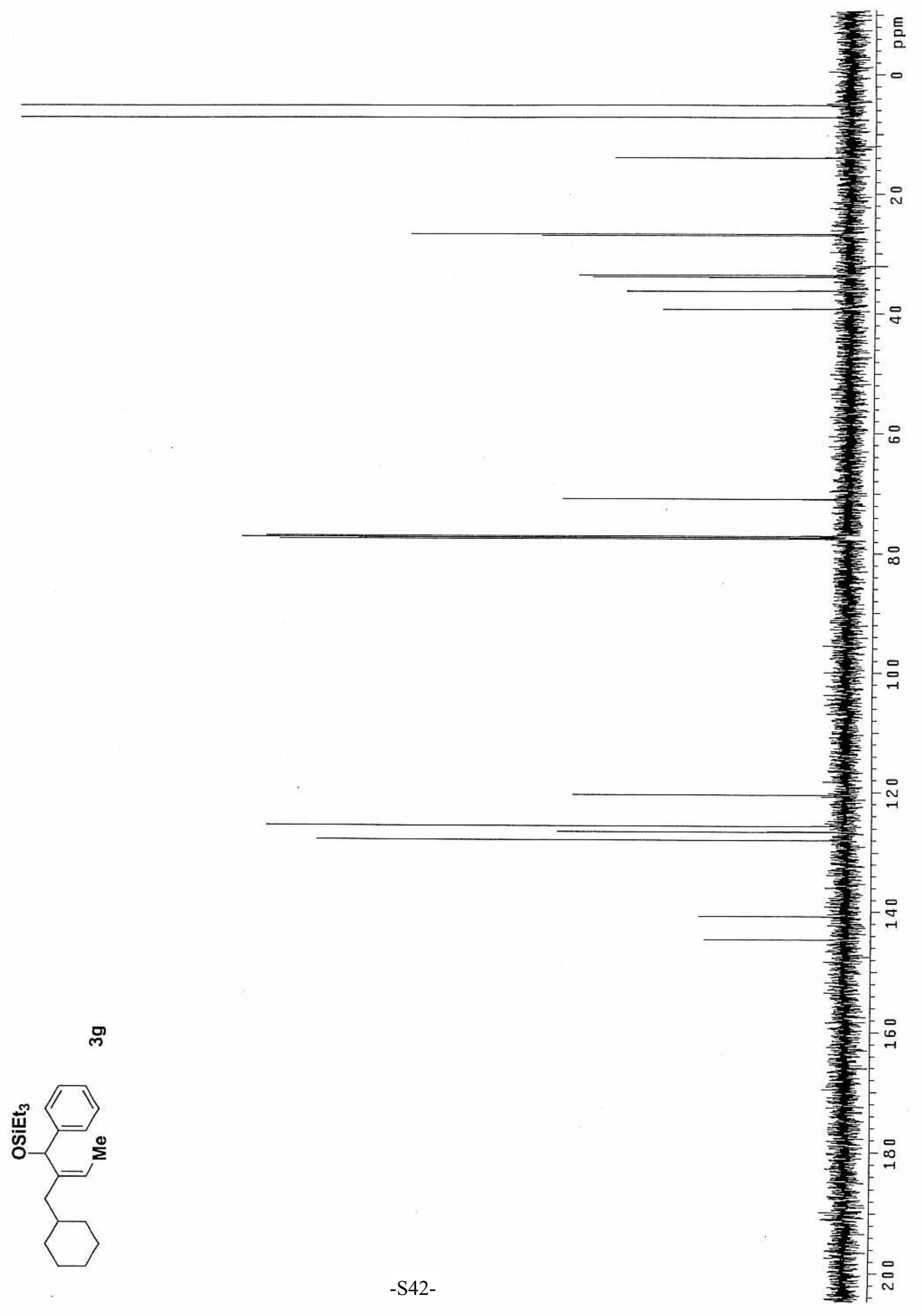



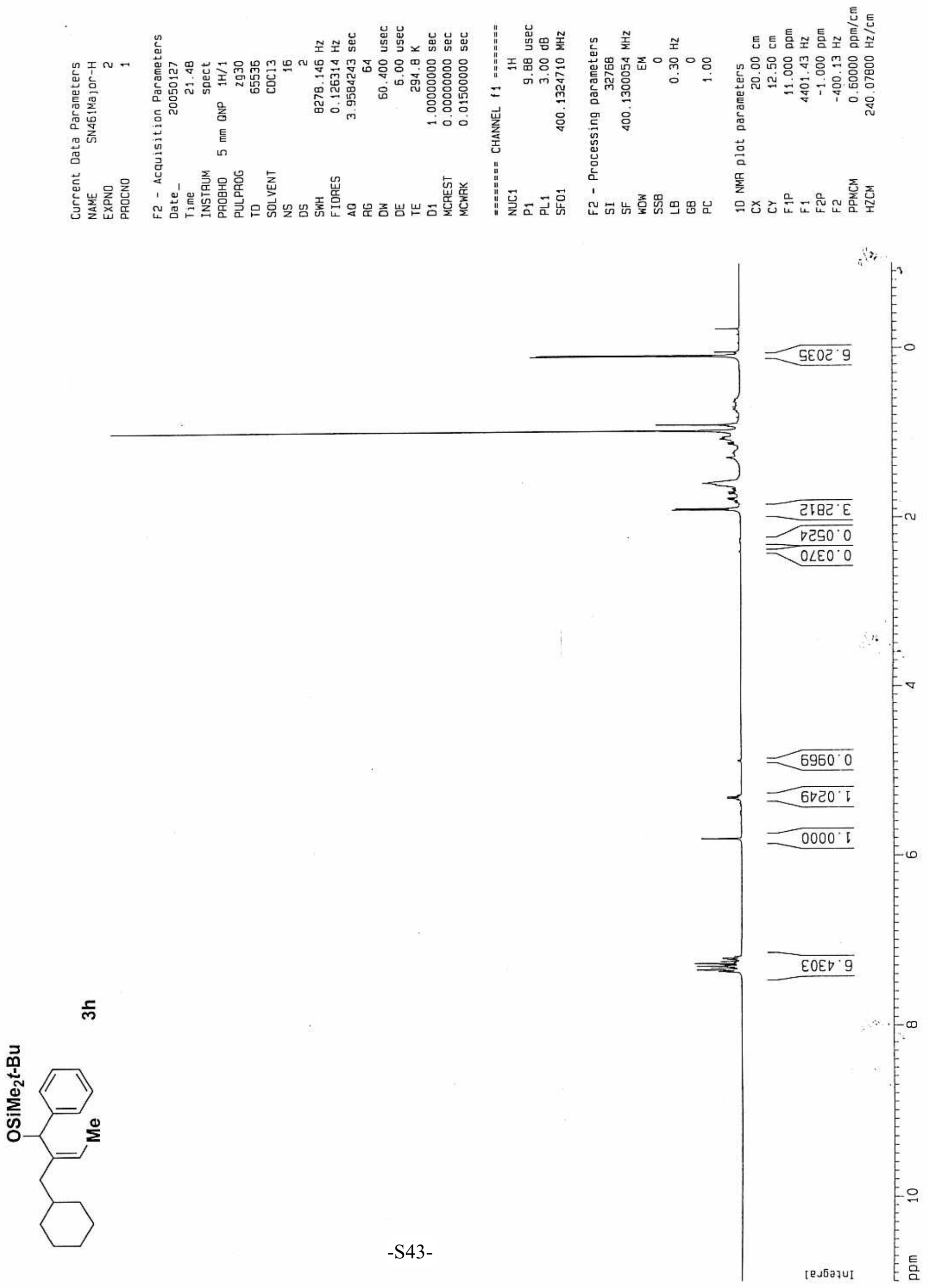


$$
1
$$




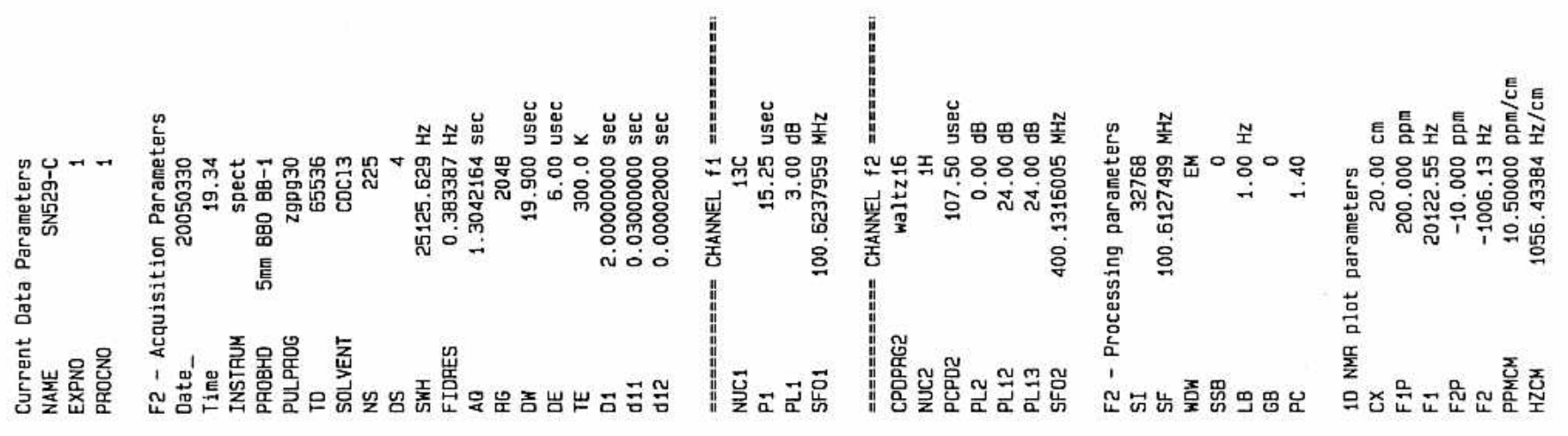

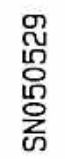

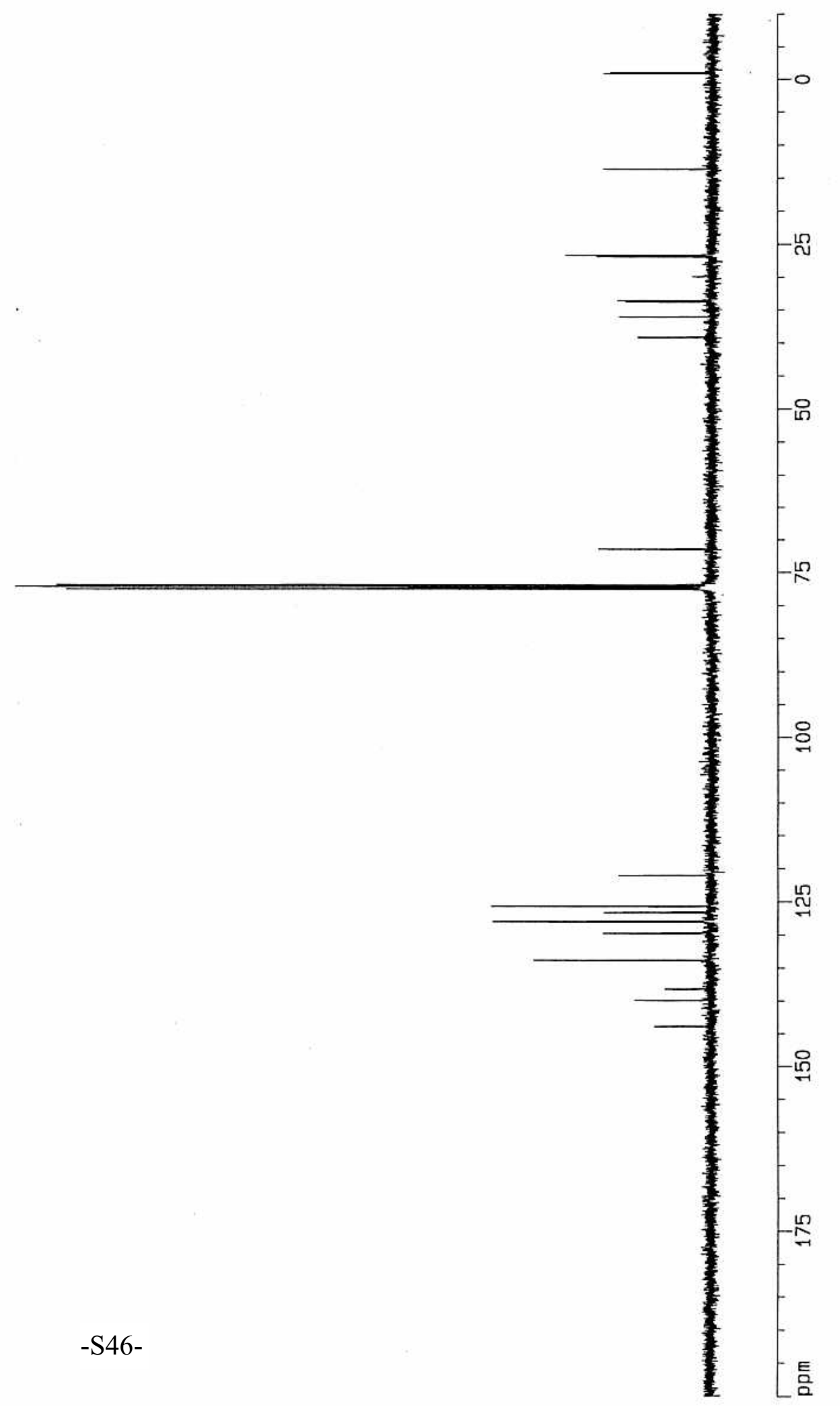




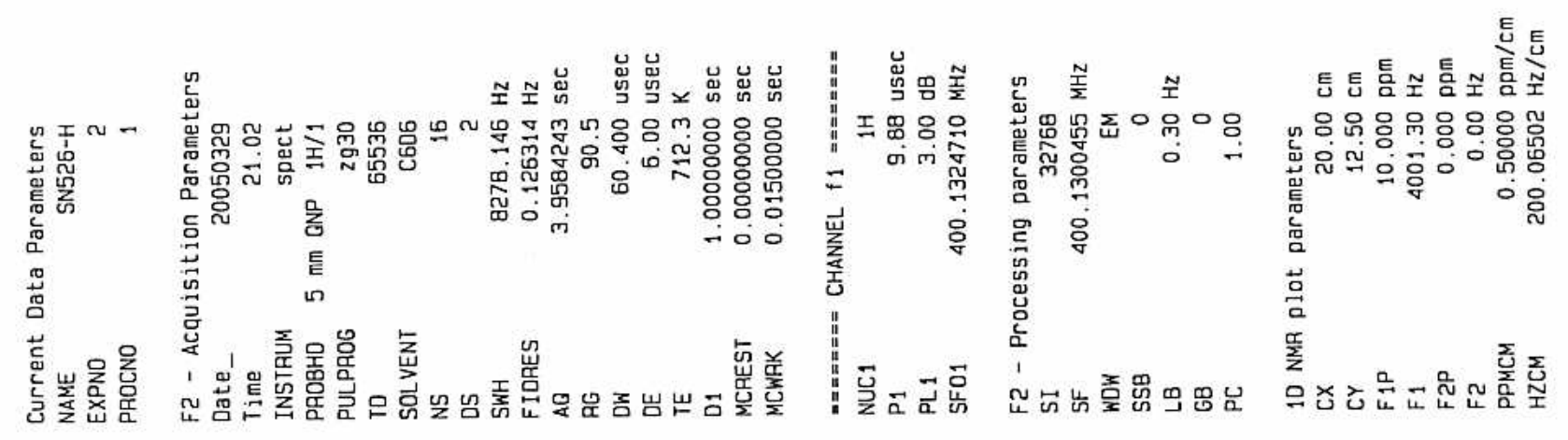

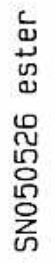
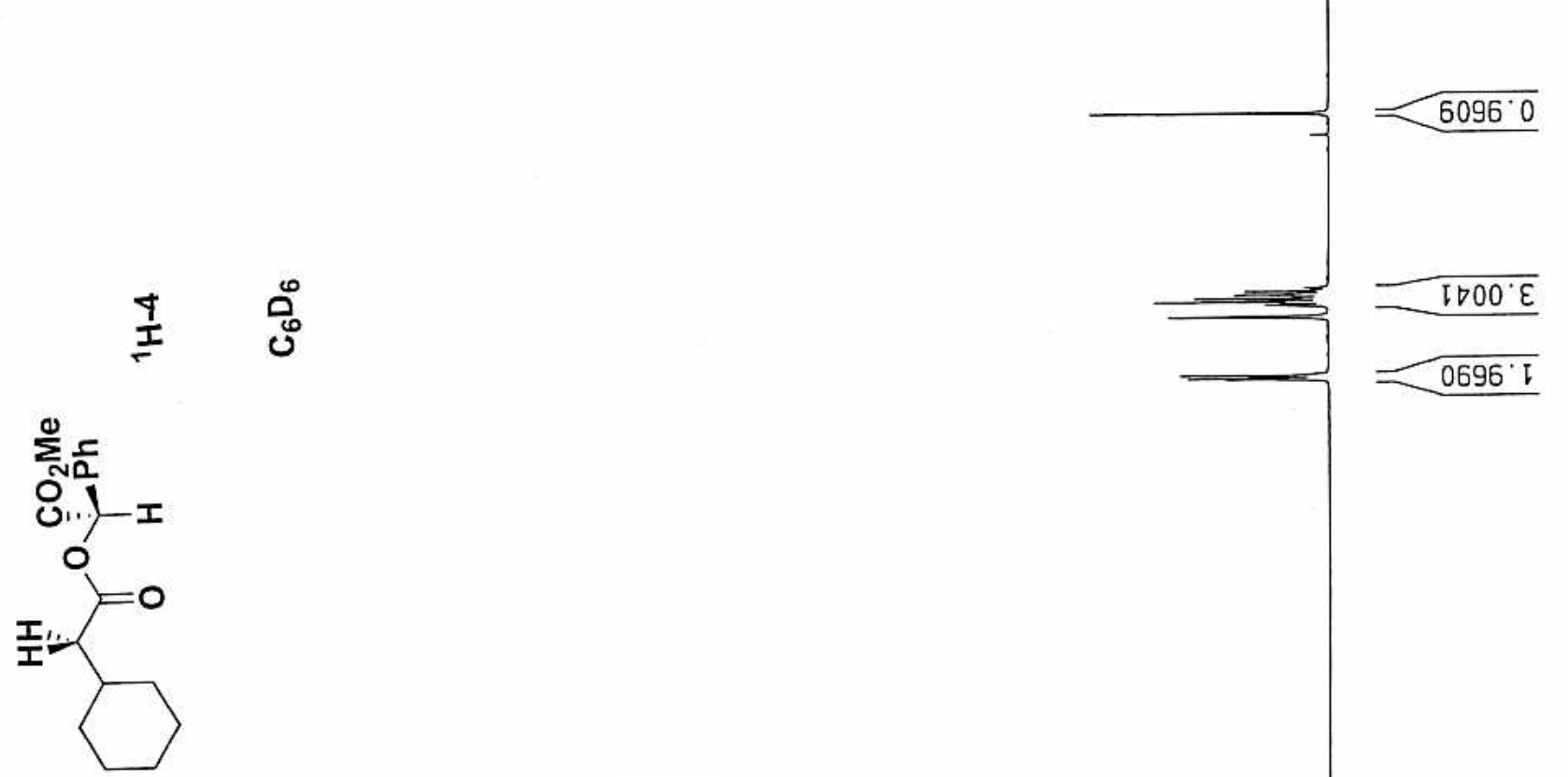

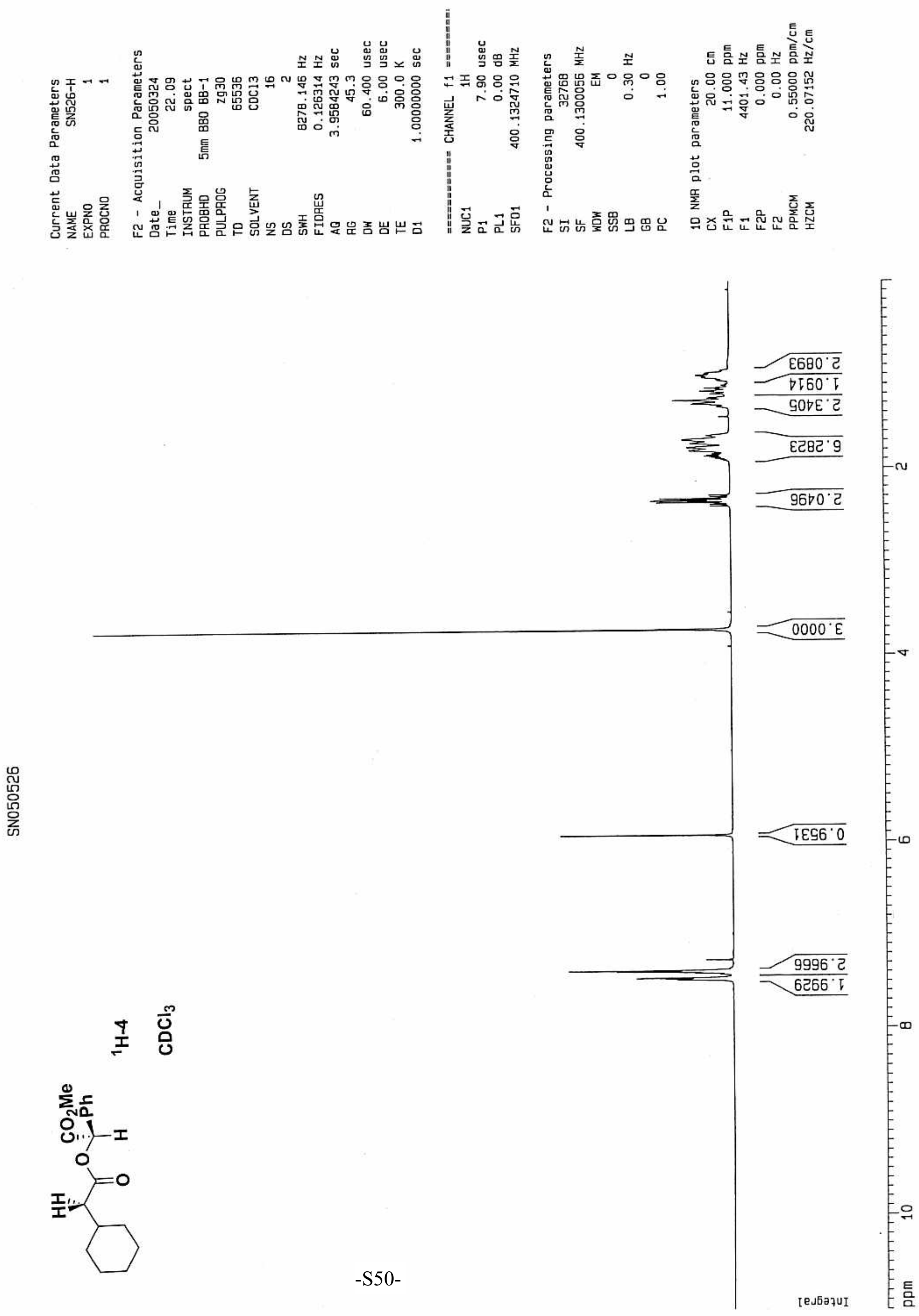


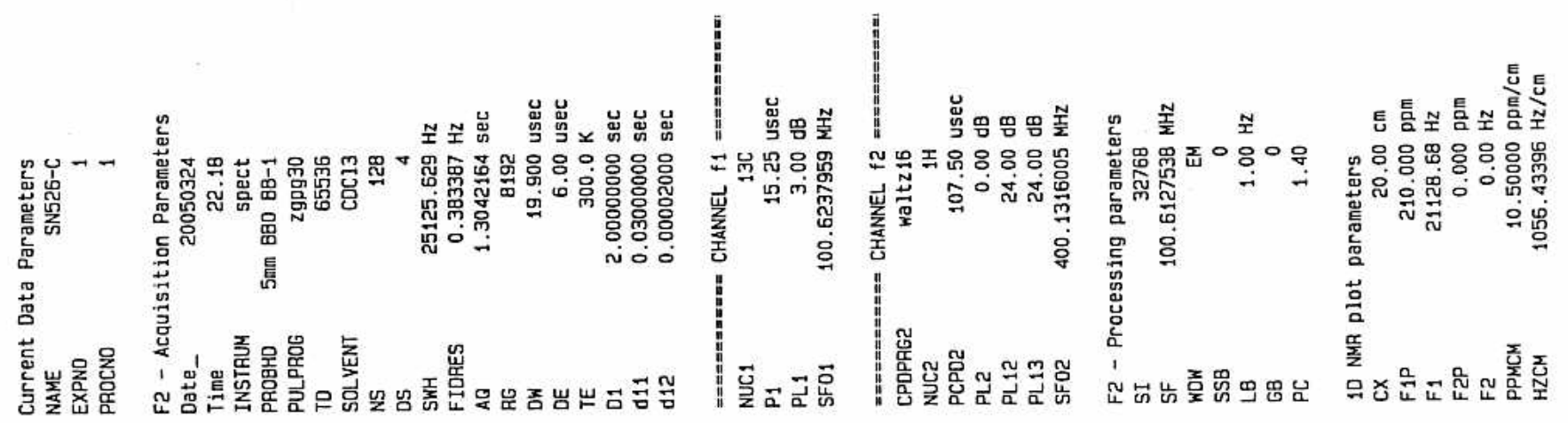

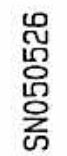

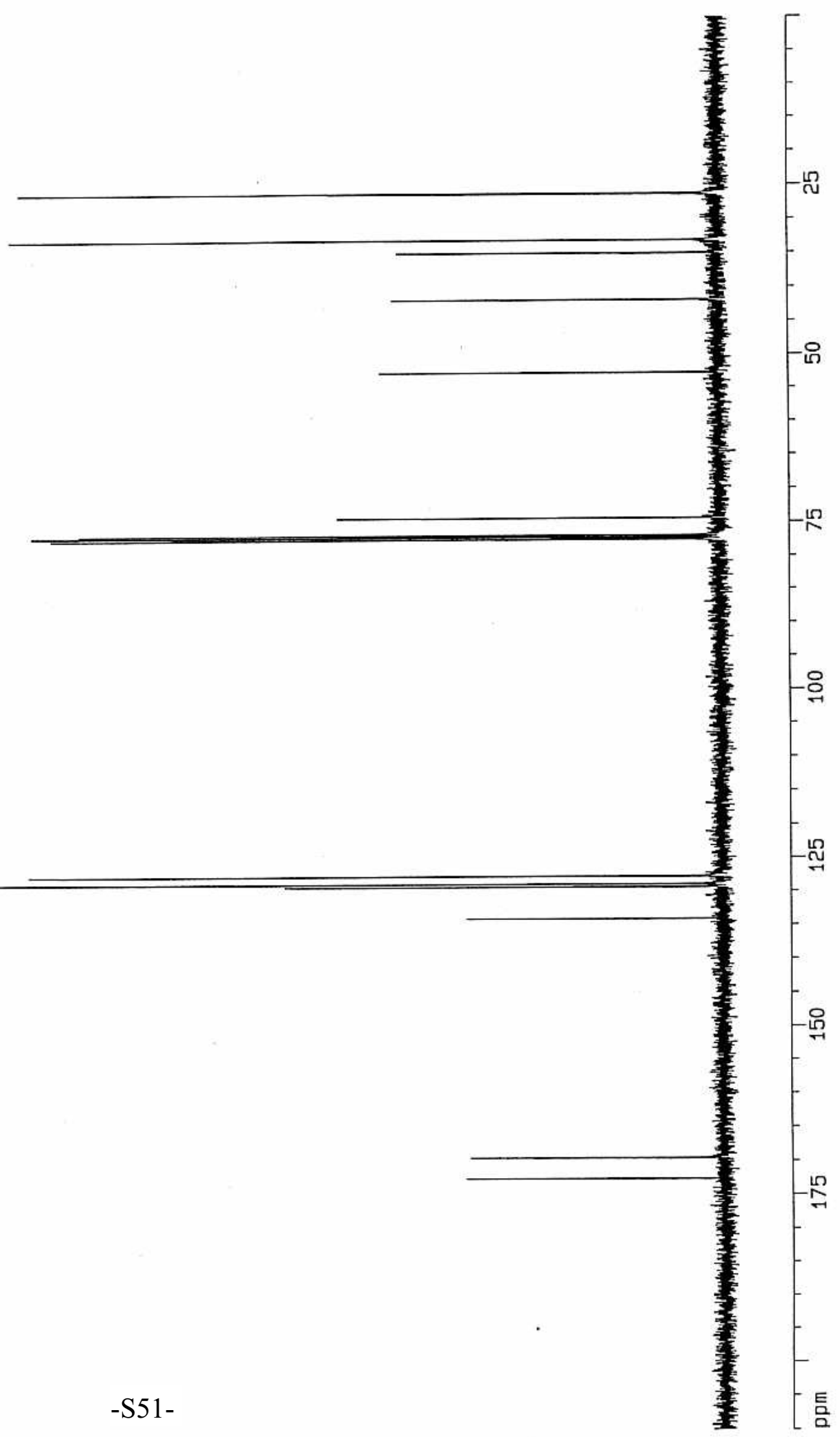



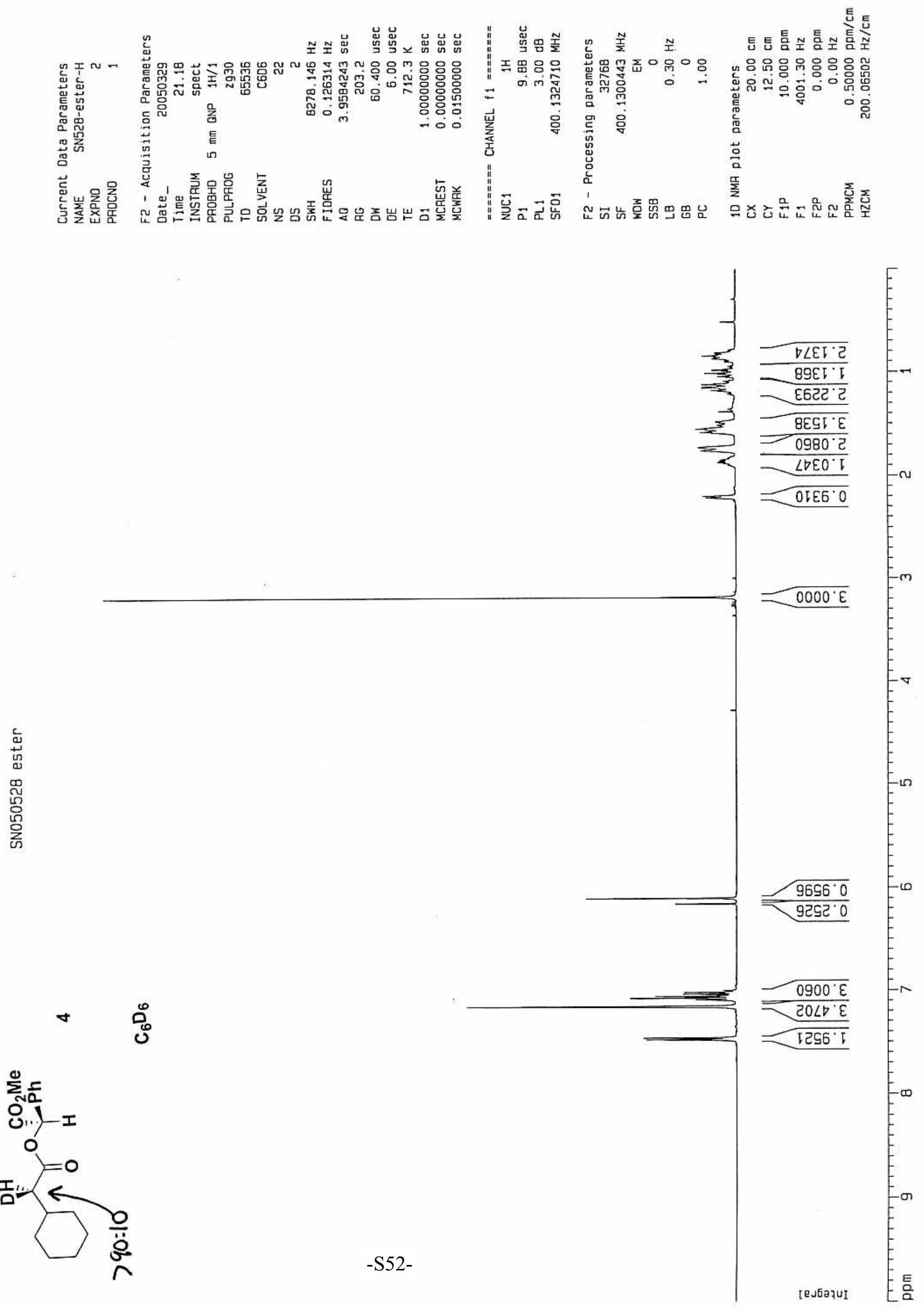

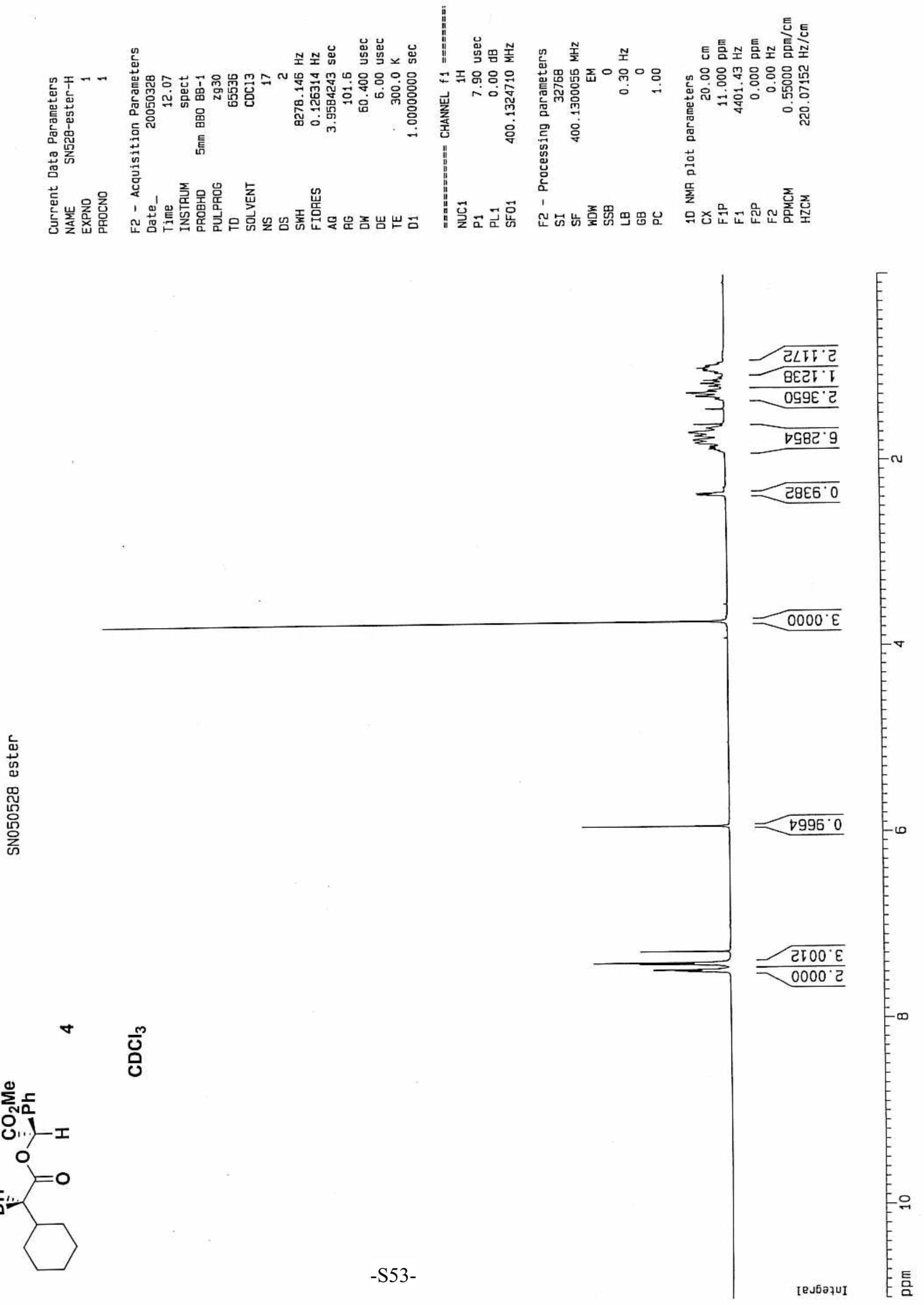


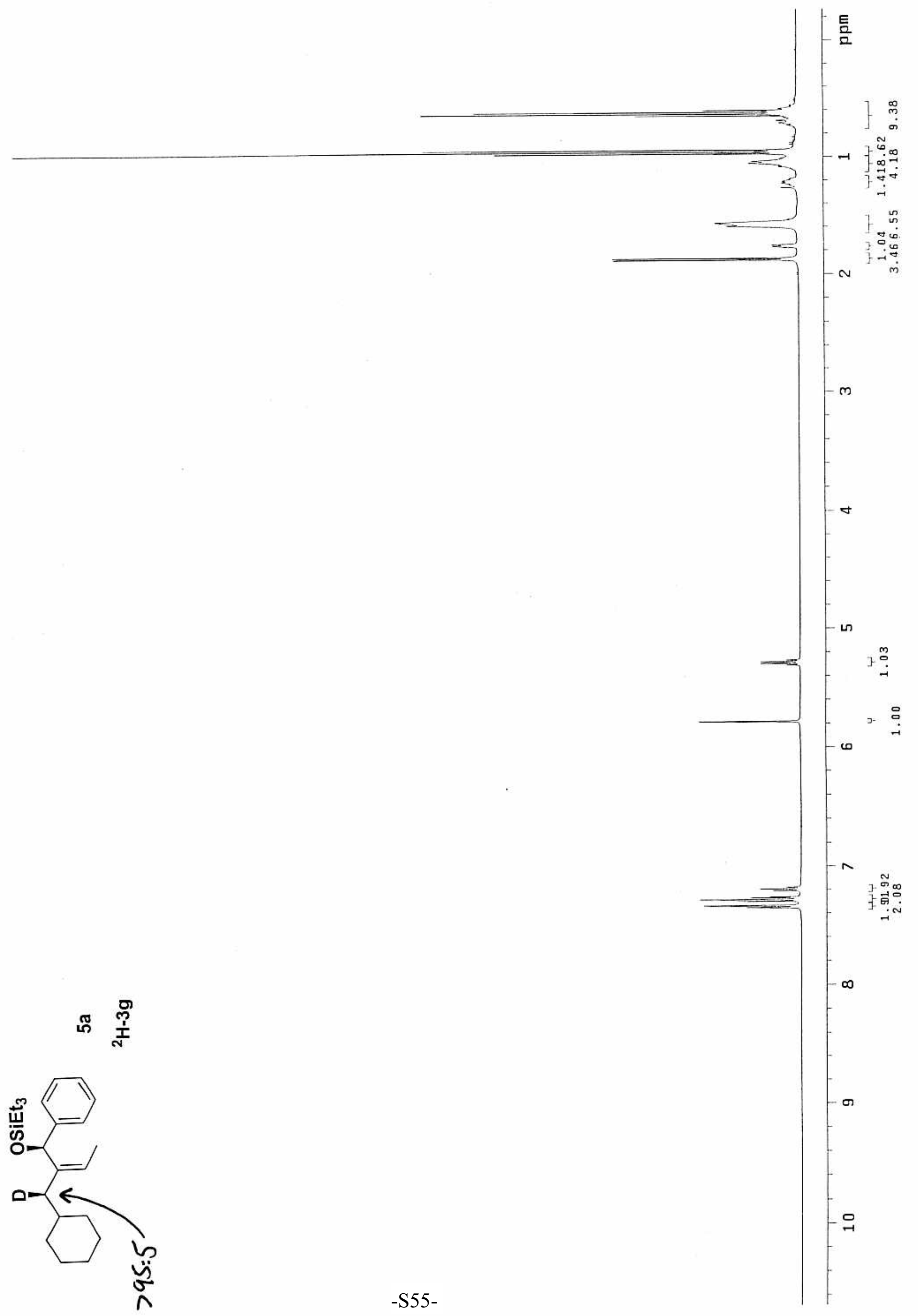




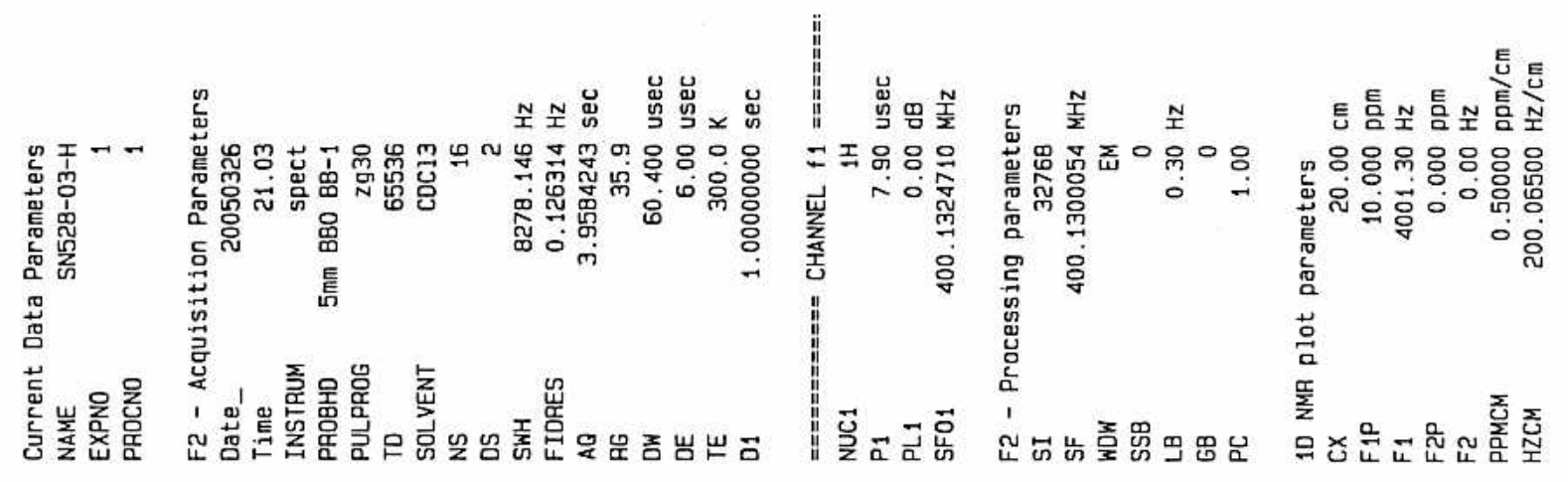

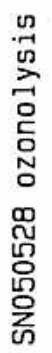

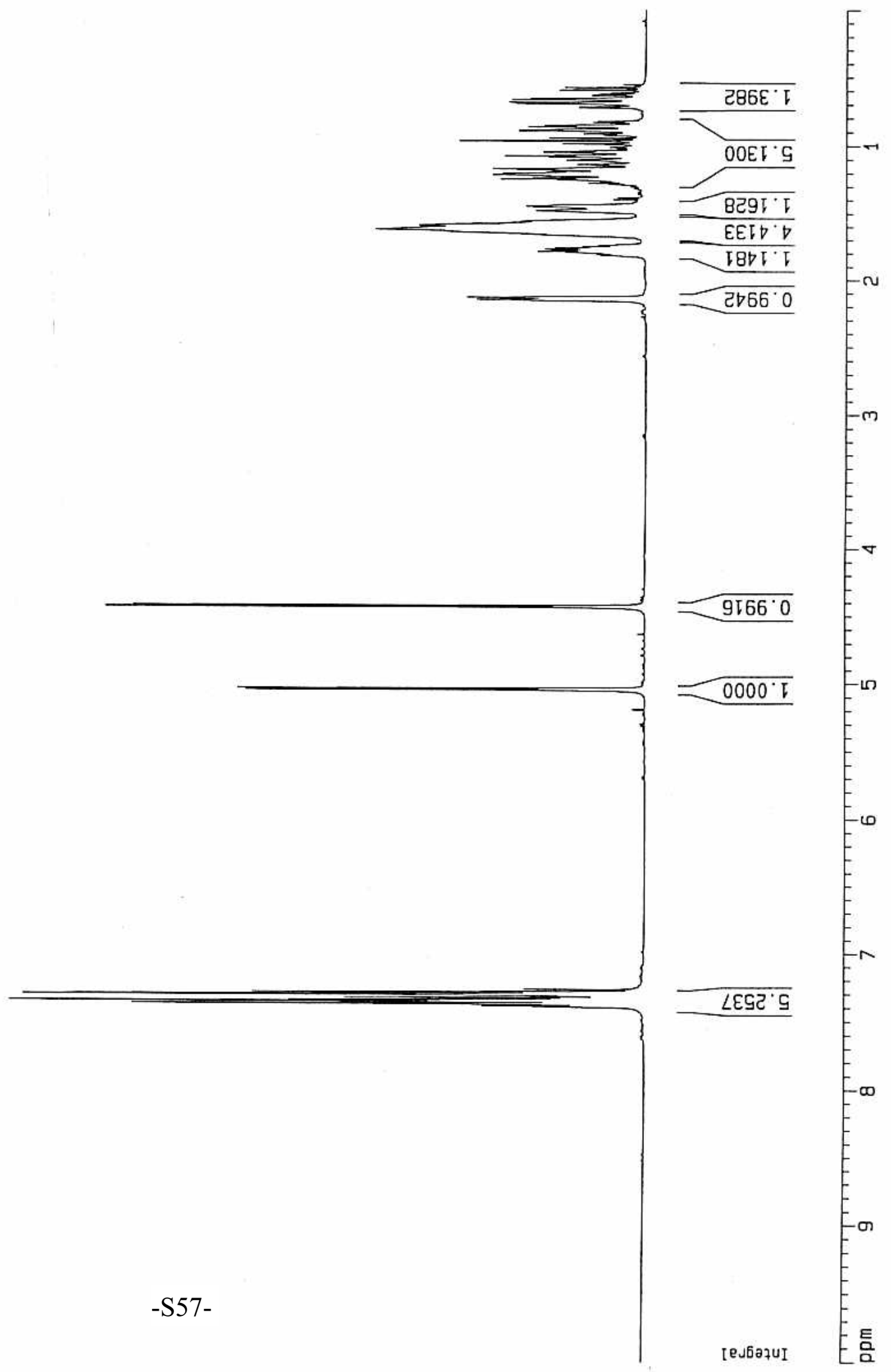




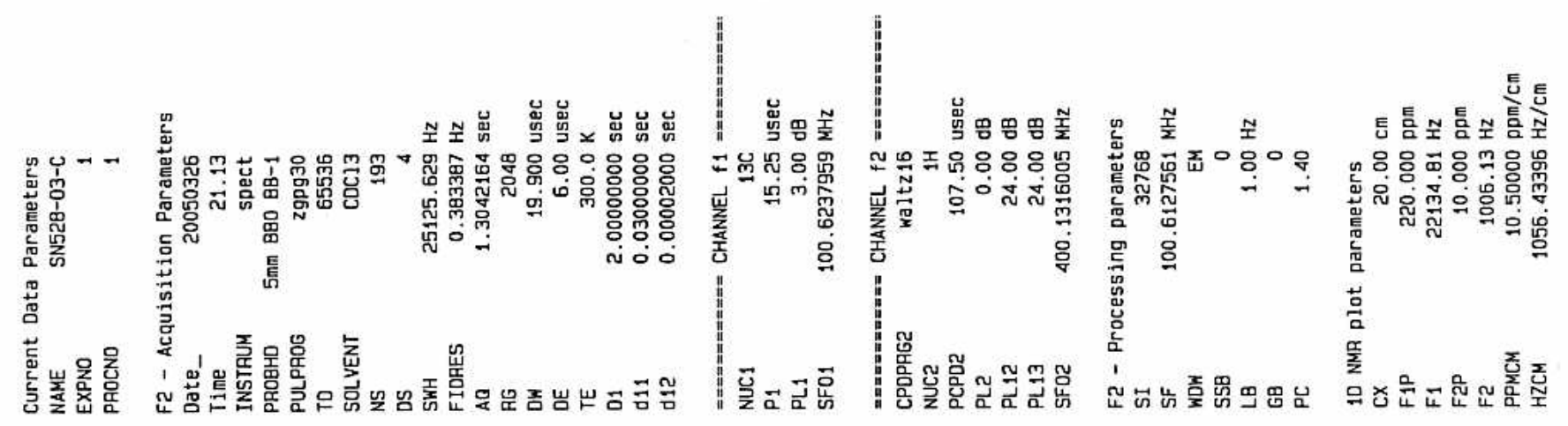

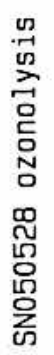

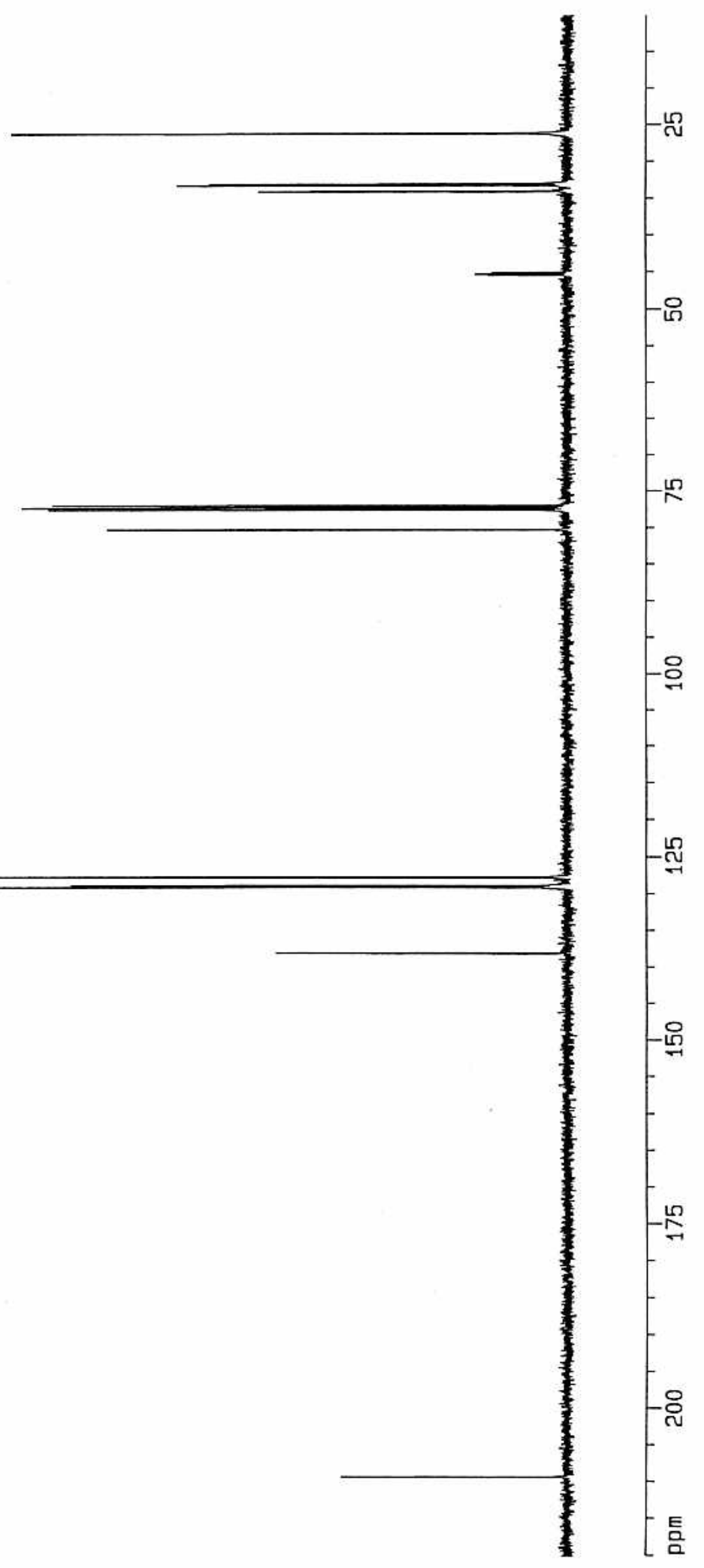



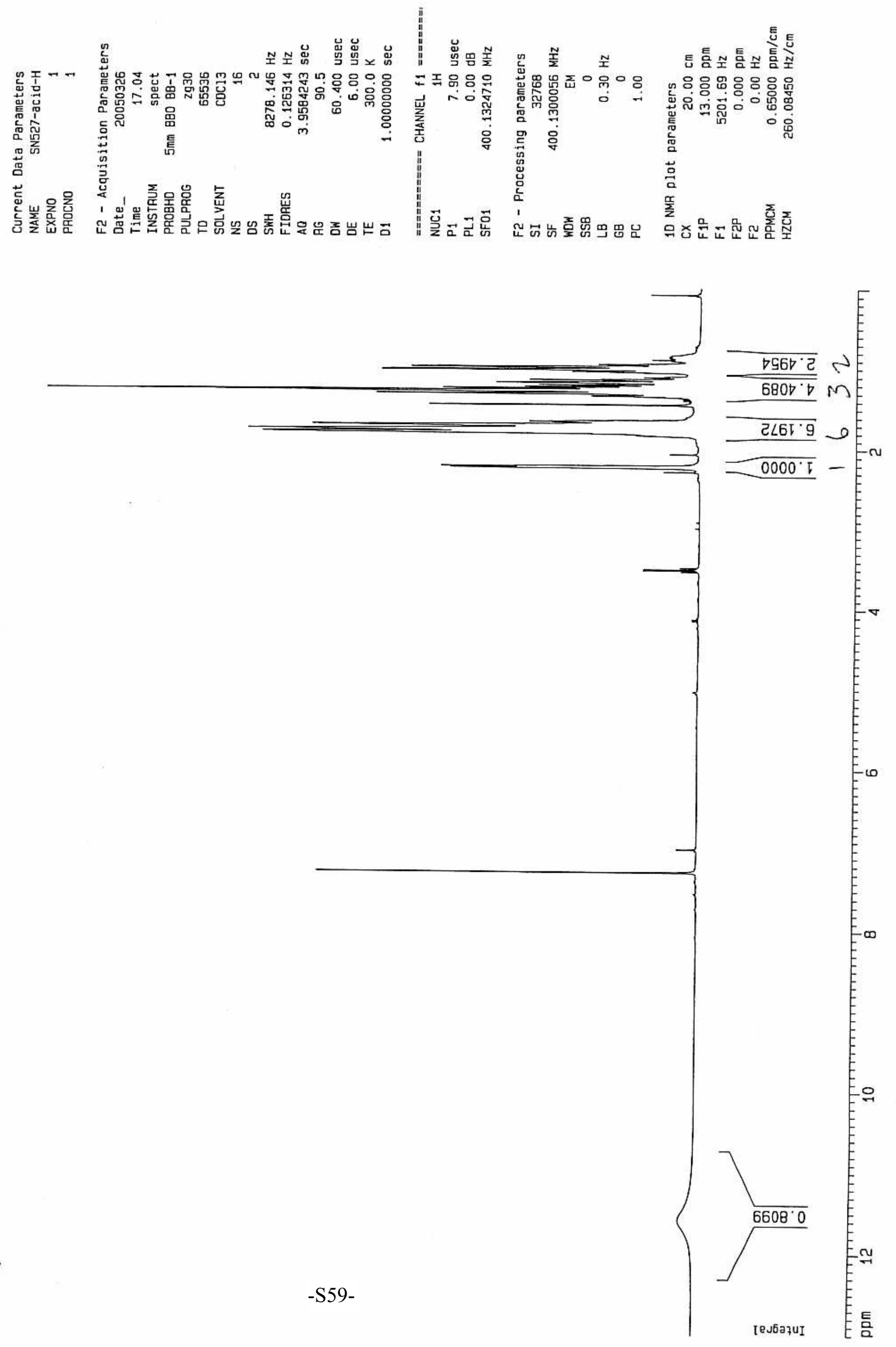


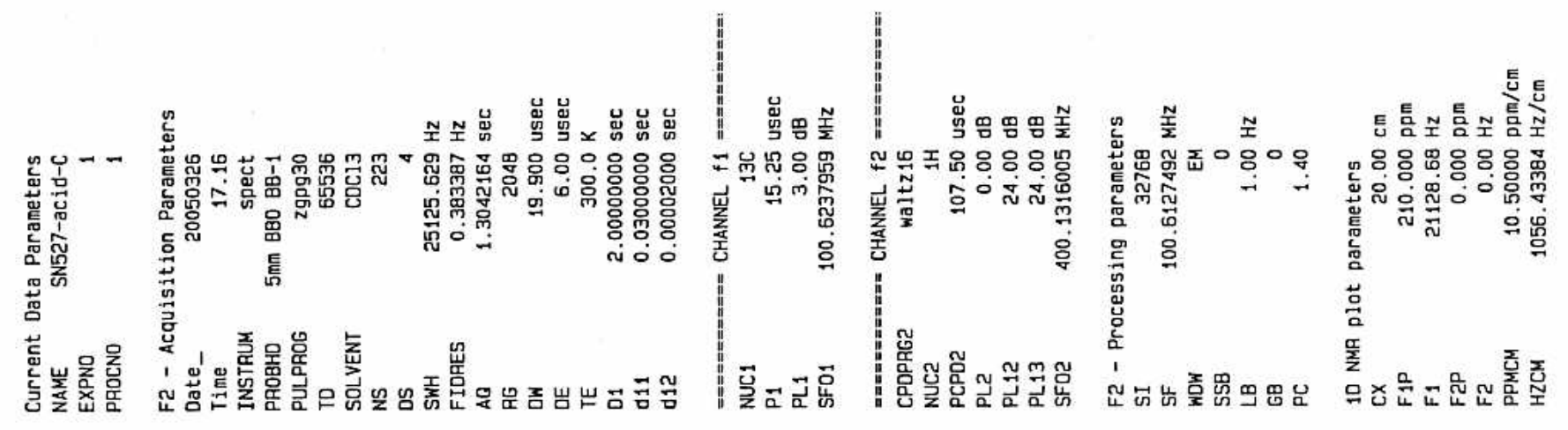

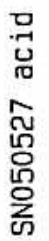

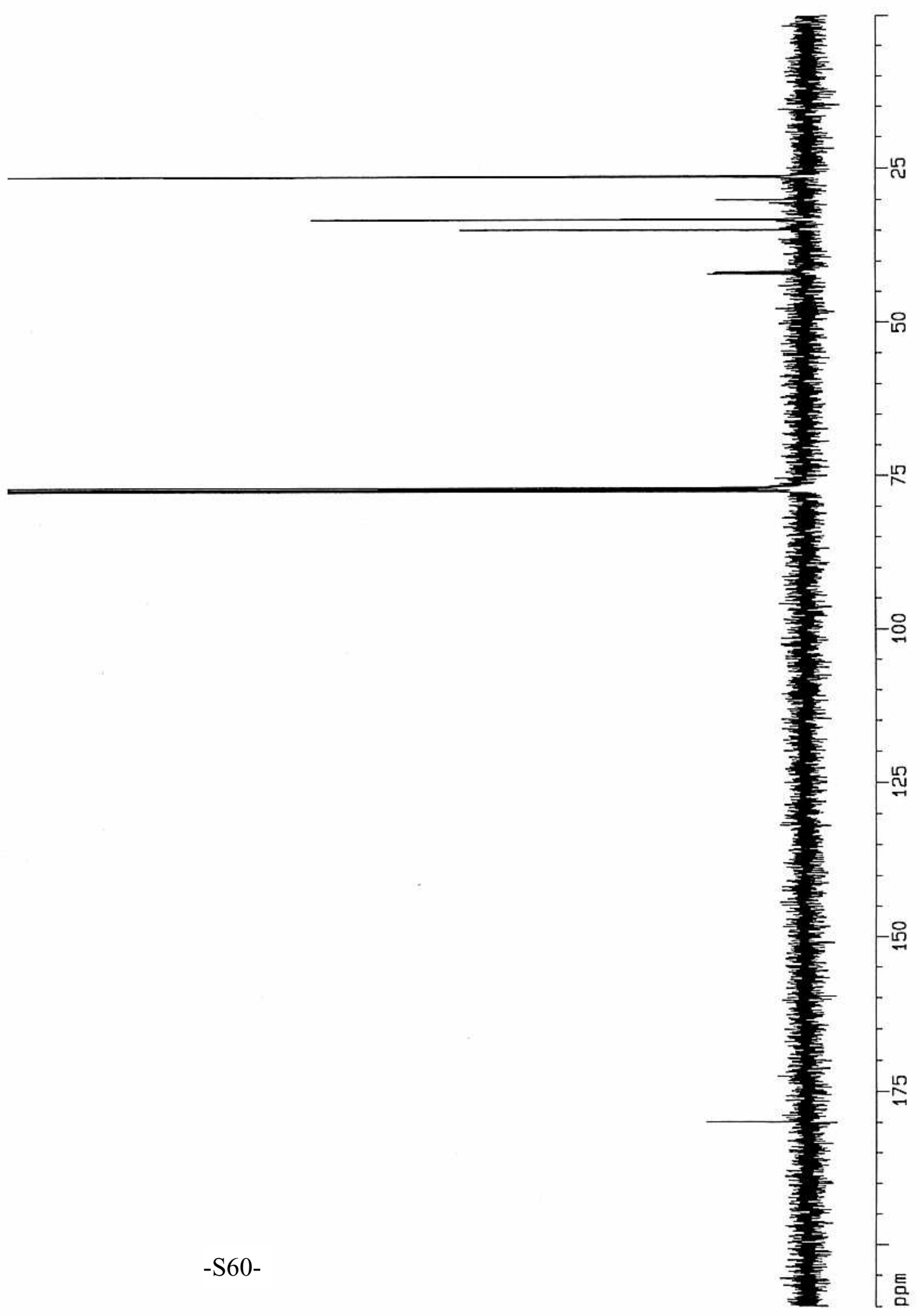



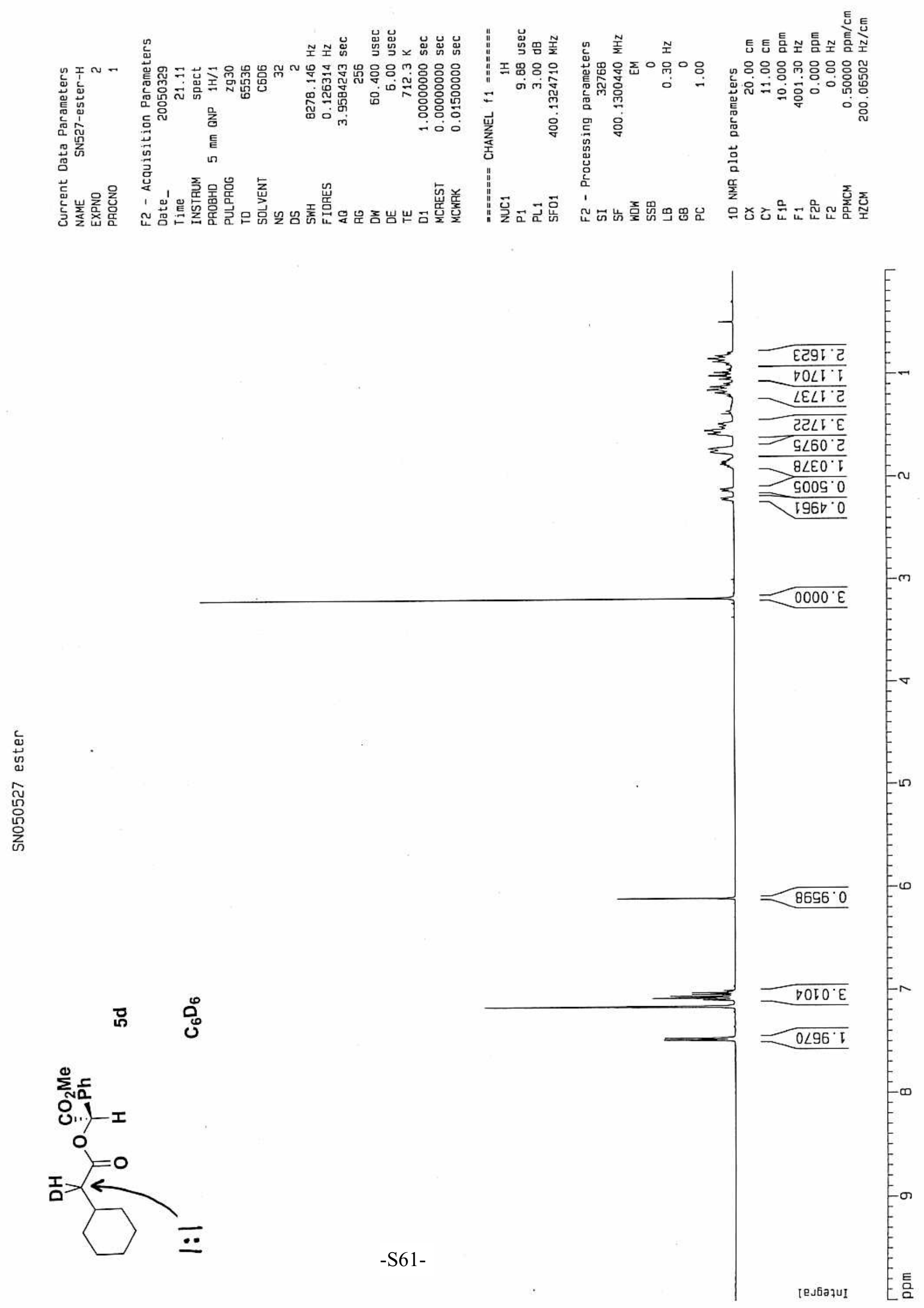

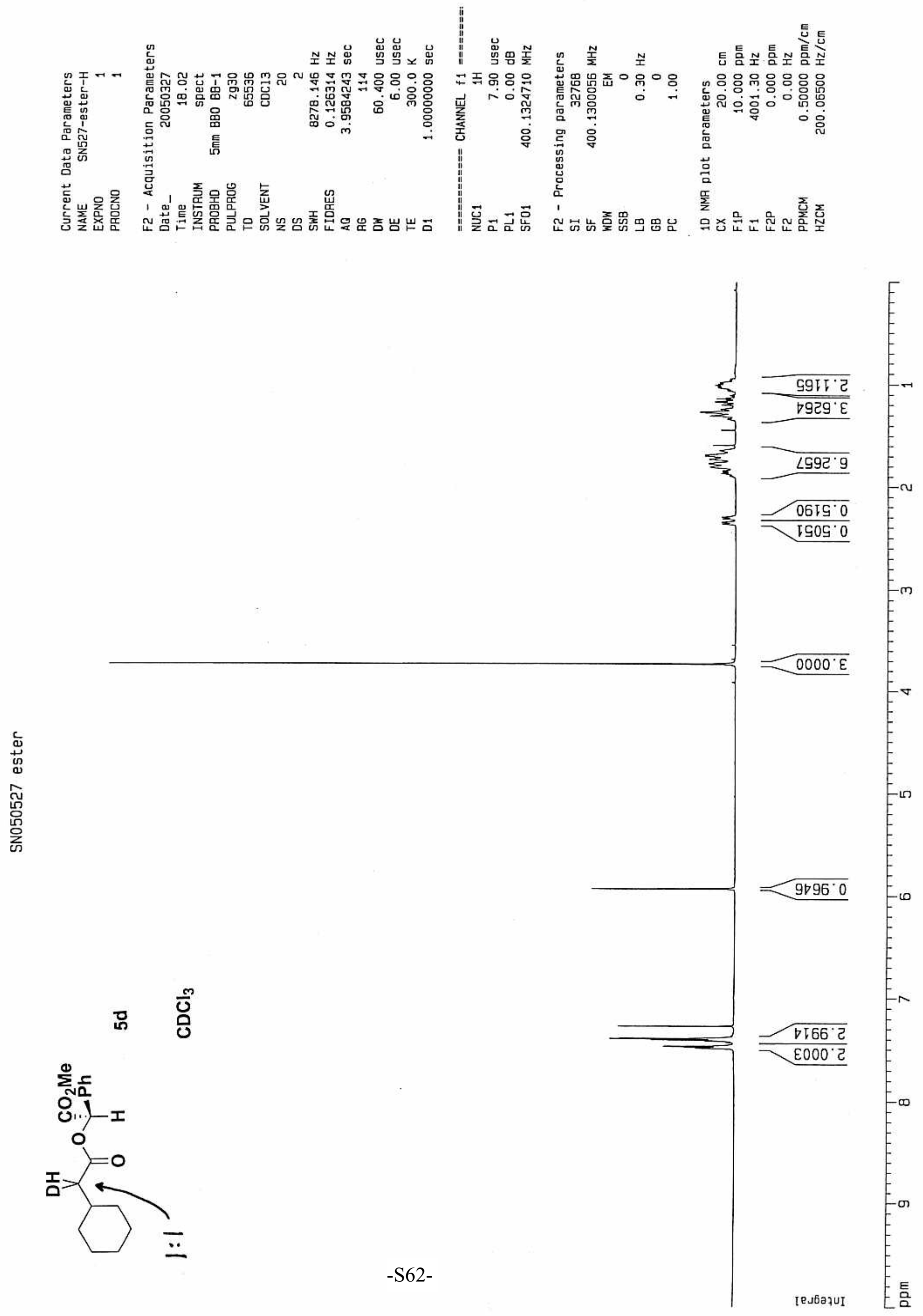


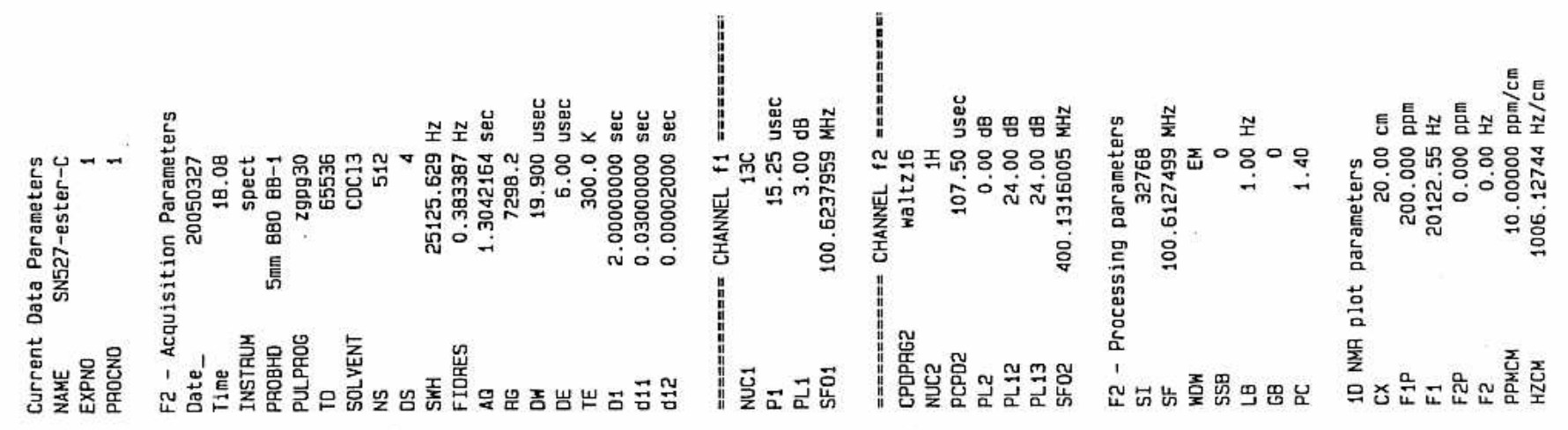

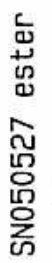

모 윰

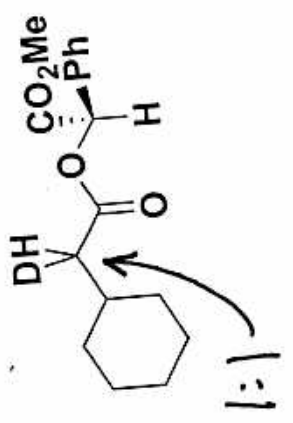

